\title{
The Limits of Popular Sovereignty: Using the Initiative Power To Control Legislative Procedure
}

At least since the seventeentli century, when political uplieaval forced a broad inquiry into the principles of government, English-speaking society has struggled to reconcile two sovereignties: the supreinacy of representative government and the supreinacy of the people theinselves. John Locke's Second Treatise of Government frained the dilemma. After observing that "tliere can be but one supreine power whicl is the legislative," Locke added that "tle legislative being only a fiduciary power to act for certain ends, there remains still in the people a supreme power to remove or alter the legislative." Anglo-American conceptions of "the people" and of the "certain ends" for whicll legislatures act liave changed dranatically since Locke's defense of the Glorious Revolution. But the tension between competing sovereignties persists. Califorinia voters revived this conflict in a novel context when they approved Proposition 24 in the June 1984 election.

\section{I}

\section{A Vote of the People: A Constitutional Conflict}

Proposition 24 restructured the internal procedure of the California Legislature to give tlie mimority party more power. This statutory initiative also cut the funding for the legislature by thirty percent. The issue now posed is whetlier the voters or only their representatives can establisl rules for legislative procedure. If the voters do sliare in this power, can they exercise it by initiating new statutes or only by anending the constitution? Controlling tlie debate about such questions are two clauses of the Califonia constitution, which Proposition 24 now draws into apparent conflict. This Comment evaluates the extent of that constitutional conflict and suggests a way of resolving it. The suggested approach is very different from the one the Califorina courts followed whien they recently ruled tliat Proposition 24 is almost entirely unconstitutional. ${ }^{2}$ The courts presumed that the constitution favors parliamen-

1. J. Locke, The Second Treatise of Government 84 (T. Peardon ed. 1952) (1st ed. London 1690). For an analysis of how-and even whether-Locke resolved this dilemma, see W. Kendall, John Locke AND The Doctrine OF MAJORITY-Rule (Ill. Stud. Soc. Sci., Vol. 26, No. $2,1941)$. Kendall emphasized Locke's belief that the people have a right to revolt when a majority find their government oppressive. Id. at 107-31.

2. People's Advocate, Inc. v. California Legislature, No. 324211 (Sacramento County Super. 
tary autonomy over popular sovereignty. This Comment challenges that presumption.

Simce 1911, California's constitution has provided that "the people reserve to themselves the powers of initiative and referendum."3 The constitution defines the initiative nower as "the power of the electors to propose statutes and amendments to the constitution and to adopt or reject them."4 This initiative process embodies a philosophic principle of established pedigree. Since it was first drafted in 1849 , the state constitution has proclaimed that "[a]ll political power is inherent in the people. Government is instituted for their protection, security and benefit and they have the right to alter or reform it when the public good may require."s

The 1849 constitution, however, included another provision concerning legislative power, which persists im nearly the same form today: "Each House shall determine the rules of its own proceedings . . . ."6 Like the provision for initiatives, the rulemaking clause reflects a fundamental tenet of representative democracy. As the California Supreme Court has noted, the inherent capacity of a legislative body to control its own proceedings is so basic that, "[i]f this provision were omitted [froin the California constitution], and there were no other constitutional linitations on the power, the power would nevertheless exist and could be exercised by a majority."7 Proposition 24 places these constitutional clauses, and the values underlying them, in conflict by enacting procedural "refornis" which fall within the legislature's rulemaking domain.

Ct., Dec. 11, 1984); People's Advocate, Inc. v. Superior Court, 181 Cal. App. 3d 316, 226 Cal. Rptr. 640 (1986). See infra text accompanying notes 8-17.

3. CAL. ConsT. art. IV, $\S 1$. California is governed today by the Constitution of 1879. Throughout this Comment, whenever former provisions in this constitution are cited they will be followed, where applicable, by a parenthetical reference to the current section of the constitution that corresponds to that former provision (i.e. "currently CAL. CoNST. art., §"). Often, the wording of the former provision has been changed in the current, corresponding section.

4. Id. art. II, §8(a).

5. See Id. art. II, § 1; CAL. CoNST. of 1849 , art. I, $\S 2$.

6. Cal. Const. of 1849 , art. IV, $\S 10$ (currently CAI. ConST. art. IV, $\S 7(a)$ ).

This study does not consider the extent to which Proposition 24 may also conflict with art. IV, $\S 11$, giving each house of the legislature the right to establish fact-finding committees to conduct business. Article IV, $\S 11$ was not intended to augment the legislature's traditionally recognized procedural authority. Rather, the clause reversed two decisions of the California Supreme Court, Special Assembly Interim Committee v. Southard, 13 Cal. 2d 497, 90 P.2d 304 (1939) and Swing v. Riley, 13 Cal. 2d 513, 90 P.2d 313 (1939), that limited the duration of legislative committees created by umicameral or bicameral resolution. See ballot arguments in California SECRETARY OF STATE, Proposed Amendments To Constitution, Propositions and Proposed Law 24 (November 1940).

7. French v. Senate, $146 \mathrm{Cal} .604,606,80$ P. 1031, 1032 (1905). The language in French exceeded the holding. See infra note 176. 


\section{A. Proposition 24 Held Invalid}

On December 11, 1984, Judge James Ford of the Sacramento County Superior Court ruled that Proposition 24 was unconstitutional. ${ }^{8}$ This was the third time in hittle more than a year that a California court had imvalidated a proposed imitiaive. ${ }^{9}$ In his written judgment, Judge Ford declared that Proposition 24 was "inconsistent with the powers of each house ... and ... beyond the scope of the statutory initiative power."10 Elaborating on his decision in chambers, the judge implied that the case presented no special difficulties because it "really comes down to a question of the Constitution of this state .... We are governed by that document." "11 According to a newspaper account, Judge Ford

held aloft a paperback copy of the Federalist, a series of articles written by Alexander Hamilton, James Madison and John Jay in 1787 to defend the U.S. Constitution.

He said a written constitution "was the genius of the (American) Revolution."

"This (case) is not a conflict between the will of the people as expressed in initiative and a disenibodied entity called the Legislature. This dispute is about the constitution."12

On May 21, 1986, the California Court of Appeal for the Third District upheld most of Judge Ford's decision in People's Advocate, Inc. v. Superior Court. ${ }^{13}$ In a per curiam opimion, the appellate court adhered to the trial judge's basic reasoning: "We are not presented with a conflict between the voice of the people expressed directly and through their elective representatives, but between two conflicting directives from the electorate: [Proposition 24] and the California Constitution."14 The court mterpreted the constitution's expression of the people's will as follows: "Rules or resolutions which affect the selection of the officers of the houses or their rules of proceeding or rules for their committees or their employees are the exclusive prerogative of '[e]ach house' of the Legislature or the combined houses."15 Thus, the court held that the imitiative

8. People's Advocate, Inc. v. California Legislature, No. 324211 (Sacramento County Super. Ct., Dec. 11, 1984).

9. In Legislature of Cal. v. Deukmejian, 34 Cal. 3d 658, 669 P.2d 17, 194 Cal. Rptr. 781 (1983), the court invalidated an initiative reapportionment plan. In American Fed'n Labor v. Eu, 36 Cal. 3d 687, 686 P.2d 609, 206 Cal. Rptr. 89 (1984), the court kept a balanced budget measure off the ballot. See infra note 89 .

10. People's Advoeate, Inc. v. California Legislature, No. 324211, slip op. at 1 (Sacramento County Super. Ct., Dec. 11, 1984).

11. L.A. Times, Nov. 30, 1984, at 1, col. 6.

12. Oakland Tribune, Nov. 30, 1984, at A12, col. 4.

13. 181 Cal. App. 3d 316, 226 Cal. Rptr. 640 (1986).

14. Id. at 322, 226 Cal. Rptr. at 643.

15. Id. at 325,226 Cal. Rptr. at 645 . 
power "do[es] not include the power to regulate the internal workings of the houses,"16 and that all but a few sections of Proposition 24 are invalid. ${ }^{17}$

This decision takes bold, simple strides across difficult and uncharted constitutional terrain. The court's conclusion is clear: voters cannot interfere with the internal procedure of the legislature. But the court's reasoning is unsatisfying, for it rests on unexamined premises. First, the court adopts a particular interpretation of the rulemaking clause without verifying its accuracy. The court assumes the clause to inean that "the power of a legislative body to govern its own internal workings [is] essential to its functioning . . ."18 This may be what the clause signifies; indeed, others in the legal world share the court's view. ${ }^{19}$ But the truth is that the origins and theoretical underpinnings of the rulenaking clause are uncertain. The imperative of procedural autonorny is only one-and perhaps the least plausible - of several principles that the clause may embody.

Secondly, the court assumes a particular scope of the initiative power, derived largely froin its analysis of the rulemaking clause. Rather than independently examine the initiative power's reach, the court

16. Id. at $327,226 \mathrm{Cal}$. Rptr. at 647.

17. The court of appeal reversed the trial judge's ruling that the open meeting and public accounting provisions of Proposition 24 were not severable from the initiative's other invalid sections. People's Advocate, 181 Cal. App. 3d at 330-34, $226 \mathrm{Cal}$. Rptr. at 648-51. The court declined to determine the constitutionality of these provisions, which thus remain law. Id.

18. Id. at $322,226 \mathrm{Cal}$. Rptr. at 643.

19. See Joint Hearing of the Senate and Assembly Judiciary Committees on Proposition 24 (May 4, 1984) [hereinafter cited as Joint Hearings]. Of the thirteen outside witnesses who submitted statements at this statutorily required hearing (see CAL. ELEC. CODE $\S 3523.1$ (West 1984)), six addressed the issue of the proposed measure's constitutionality. Two of these witnesses (Professor Robert Post, School of Law, University of California at Berkeley and Professor Robert Welsh, Umiversity of California at Los Angeles) argued that the initiative was unconstitutional. Joint Hearings, at 45, 92. Three witnesses (Professor Daniel Lowenstein, School of Law, University of California at Los Angeles; Henry Dotson, Vice President of the Southern Area NAACP Branches and Attorney General John Van de Kamp) predicted that Proposition 24 would be held unconstitutional in court. Id. at 87, 102, 175. The sixth witness (Professor Preble Stolz, School of Law, University of California at Berkeley) asserted that the courts could make a defensible argument for either the measure's validity or invalidity. Id. at 53 .

Professor Post read the rulemaking clause as a guarantee of exclusive power over internal procedure for the legislature, noting that the parliamentary treatise by Luther Stearns Cushing (published not long after the first California constitution was drafted) had championed this view. Id. at 45 (quoting L. Cushing, Elements of The LAw AND PRACTiCe of Legislative Assemblies IN THE UNITED STATES OF AMERICA 247 (2d ed. Boston 1866)). See infra text accompanying note 113. Both Professors Post and Welsh also contended that Proposition 24 was independently invalid under the constitutional clause governing the initiative. They asserted that the initiative power was defined to exclude the range of unicameral duties (such as committee assignments, impeachment, and rulemaking) that the constitution assigned to each house of the legislature. Id. at 48,95 .

For the views of the Democratic party opponents of the initiative, see California Journal Ballot Proposition Analysis, 15 CAL. J. 143, 148 (1984) (separately paginated as 1, 6); L.A. Times, May 27, 1984, at 3, col. 4 . 
assumes that initiatives cannot embrace procedural rules because it has already decided that such rules are the exclusive prerogative of legislators. ${ }^{20}$ Here again, although the court's interpretation of the initiative clause may be valid, the underlying presumption warrants closer scrutmy.

\section{B. Reexamining Basic Issues}

This Comment attempts a fresh evaluation of the constitutional issues raised by Proposition 24. The inquiry focuses on two questions, corresponding to the two constitutional clauses governing the case. First, do any of the constitution's provisions that establish the initiative power directly prohibit the terms of Proposition 24? If none of them does, then a second question arises: Does the rulemaking clause guarantee that the legislature's rulemaking power is an exclusive one, which would indirectly preclude the terms of this initiative?

Following Part II of this Comment, which summarizes Proposition 24's provisions, Part III takes up the first of these constitutional questions-the one involvimg the scope of the initiative power im California. No evidence is found to indicate whether tle initiative power was intended to reach the legislature's imternal procedure. Part III finds, however, that the initiative power was conceived im broad terms and that this has been reflected in the constitution's provisions governing initiatives and in the state supreme court's treatment of them over the past seventy-five years.

Part IV examines the second constitutional question: whether the rulemaking clause means that procedural matters must be exclusively controlled by the legislature. Interpretation of this clause is difficult. The drafters of California's first constitution left no clue to the purpose of the rulemaking clause. Accordingly, Part IV explores the political history surrounding not only Califorma's constitution but its colomal progenitors-the constitutions of the original thirteen states, which contained the first rulemaking clauses. This historical evidence suggests several purposes that the rulemaking clause may have served. These are related to political doctrines of the colonial period such as the separation of powers and bicamerahisin. The evidence that the rulemaking clause simply conferred exclusive control over legislative procedure is less persuasive.

Thus, Parts III and IV conclude that neither the constitution's provisions governing initiatives nor its rulemaking clause clearly validate or void Proposition 24. These clauses can be interpreted to reach either conclusion. But precisely because these interpretations are uncertam and

20. People's Advocate, Inc. v. Superior Court, 181 Cal. App. 3d at 325, 226 Cal. Rptr. at 645. 
because the principles underlying each clause are so important, it is inappropriate to seize upon a single interpretation of one of the clauses-as the courts seem to have done-to invalidate this initiative.

Instead, the courts should try to harmonize principles enshrined in the state's constitution. This study concludes by proposing just such a standard of review. Part $\mathrm{V}$ argues that the voters' desire for reform should be balanced against the extent to which those reforms jeopardize the constitutional values that plausibly underhe the ruleniaking clause (such as the separation of powers, the effectiveness of legislative representation, and the theory of bicaneralism). When Proposition 24 is assessed by this standard, a fairly convincing case can be nuade for its constitutionality. That conclusion is not, however, inevitable. Consequently, the discussion below does not rest its argunients on the achievement of a particular legal result. What is paramount is that courts recoguize that there are competing values at work in this case, that the plain language of the constitution does not vindicate any of then, and that the conflict cannot be resolved by invoking "powers . . . deeply rooted in constitutional soil"21 or by appealing to the Founding Fathers.

\section{Dispelling Preconceptions}

A fresh examination of this conflict between popular and representative sovereiguty must overconie powerful preconceptions. The doniain of legislative procedure will strike inost people as inhospitable territory for the exercise of the initiative power. Intuitively, legislative procedure seenus like the sort of thing that legislators ought to control. It is difficult to imagine a contrary arrangement, as the courts' rulings against Proposition 24 denionstrate.

On reflection, however, it should be clear that this "intuitive" response is historically conditioned. Our sense of legislative procedure as privileged terrain is fostered in part by legislators themselves ${ }^{22}$ and strengthened by the courts' practice of deferring to a coordinate branch of government whenever legislative procedures are legally challenged..$^{23}$

21. Id. at $322,226 \mathrm{Cal}$. Rptr. at 643 .

22. Eulogies for the late Senator James Allen, who was hailed by his colleagues as a "wizard of the rulebook," illustrate the special aura which surrounds parliamentary procedure. See, e.g., N.Y. Times, June 2, 1978, at B2, col. 1 (obituary recalling Senator Sam Ervin's remark that "if he had 'to stand with one man at Armageddon and battle for the Lord,' he hoped that man would be [Senator] James Brownimg Allen of Alabama"). Further evidence of the importance that legislators attach to rules can be found in the House of Representatives' published record of procedural precedents. This now comprises fifteen volumes. See L. DEsCHLER, DESCHLER's PRECEDENTS OF THE UNITED States House of Representatives (1977); C. Cannon, Cannon's Precedents of the House of REPRESENTATIVES OF THE UNITEd STATES (1935); A. Hinds, Hinds' PRECEDENTS OF THE House of RePRESENTATIVES OF THE UNITEd STATES (1907). For further discussion of the status of procedural rules, see infra note 254 and text accompanying notes 267-71.

23. See infra text accompanying notes 253-66. 
Parliamentary custom is thus treated as the legislators' unique and complex brancli of law, and voters are discouraged from intruding. ${ }^{24}$

In addition, since the initiative power lias never before been extended to procedural matters, the novelty of Proposition 24 may be mistaken for inıpropriety. The traditional function of imitiatives, after all, lias been to supplement the work of the legislature, not to control the way that work is conducted. Yet again, habit, ratler than logic or constitutional strictures, may condition this view of initiatives. Using the initiative to reform the legislative process could, in fact, be less radical than its traditional use. Legislatimg by initiative for a diverse state of more than twenty million people (in elections dominated by simplistic media) poses obvious risks. ${ }^{25}$ It may make more sense to redress perceived abuses in legislative procedure so that laws that the voters desire can be developed properly througli a deliberative process. At the least, that possibility should be kept in mind as the constitutional questions raised by Proposition 24 are reexamined.

\section{II \\ A "REFORM" INITIATIVE}

Proposition 24 repealed eigliteen sections of the Government Code and added thirty-five new ones. The new law set forth the powers, membership-selection process, and voting requirenients of the Senate and Assembly Rules Committees and of the Joint Rules Committee; ${ }^{26}$ the metlod of selection for all other committee chairpersons, vice-chairpersons, and members (imcluding requirements for partisan balance); ${ }^{27}$ the voting procedures on the floor of both cliambers; ${ }^{28}$ notice and open-meeting requireinents for eacl chamber and its committees; ${ }^{29}$ voting requirements for adoption of standing rules in each cliamber (as well as for their

24. See, e.g., R. BOLLING, HOUSE OUT OF ORDER (1965), especially chapter 1. Congressman Bolling agreed with an earlier commentator that, to constituents visiting Capitol Hill, "the proceedings of Congress [would resenble] a theatrical production on which the curtain never rises," as though the constituents "'were seated in a huge auditorium, allowed printed programs, but kept in total ignorance of what was happening on stage." " Id. at 22 (quoting S. BAILEY, CONGRESS MAKES A LAW vii (1950)).

25. See, e.g., D. MAGLEBy, DiRect Legislation 183 (1984) ("One problem is that voters are not permitted to vote on alternate bills; another is that voters cannot attempt to amend the proposed legislation to make it more acceptable. An additional problem is that voters are limited to an affirmative vote, a negative vote, or an abstention. Because of the way in which propositions are worded, voters often must choose the least inaccurate expression of their opinion.").

26. CAL. Gov'T CoDE $\S \S 9911-9913,9915-9917$ (West Supp. 1986). Sincc most of Proposition 24 has been held unconstitutional, the sections that codify these provisions in the Government Code are now void. However, to facilitate discussion, this Comment will refer to Proposition 24's provisions by their Code section numbers, even though these no longer have legal significance.

27. Id. $\S \S 9922-9924$.

28. Id. $\$ 9925$.

29. Id. $\S 9926$. 
suspension); ${ }^{30}$ and rules for allocating members' and committees' staffs and funding in proportion to party membership. ${ }^{31}$ In addition, the measure mandated a thirty percent reduction in appropriations for the legislature. ${ }^{32}$

Several "findings" accompanied these proposals for structural change. They assailed as threats to equal representation the "concentration of power $m$ the office of Speaker of the Assembly and, to a lesser extent, $m$ the office of President pro Tempore of the Senate," 33 the "system of patronage and punishment"34 which that power has fostered, the "growth in abusive voting practices,"35 and the "distribution of funding, staff and informational resources ... according to predominantly partisan criteria."36 Some of the initiative's provisions merely replaced existimg statutes, ${ }^{37}$ others displaced current standing rules, ${ }^{38}$ and some others covered matters not presently governed by laws or rules. ${ }^{39}$ All of the provisions (except the cut in funding) concerned points that could be treated by the joint or respective rules of the senate and assembly.

Behimd Proposition 24's lofty declaration of reformist sentiments lurked a host of pohtical motivations. As one journatist described the initiative's genesis, "[a]nger sparked it, Republicans wrote it, Paul Gann put his name on it, and resentment made it fly with the voters." 40 The anger flowed from assembly Republicans, some of whom had forged the coalition that first elected Willie Brown Speaker in 1980, but who came to resent the increasing partisanship of Brown's reign. ${ }^{41}$ The assembly

30. Id. $\S \S 9920-9921$.

31. Id. $\S \S 9931-9932$.

32. Id. § 9934.

33. Id. $\S 9901(\mathrm{e})$.

34. Id.

35. Id. $\S 9901(\mathrm{~b})$.

36. Id. $\S 9901$ (d).

37. For example, the initiative repealed provisions of the Grunsky-Burton Open Meetings Act, former CAL. GoV'T CODE $\$ \S 9027-9032$ (West 1980) (repealed 1984), but largely reinstated them in slightly altered form, CAL. Gov'T CODE $\$ \$ 9926-9929.5$ (West Supp. 1986). The latter are among the few provisions of Proposition 24 which were not invalidated by the court of appeal's decision. People's Advocate, Inc. v. Superior Court, 181 Cal. App. 3d 316, 330-34, 226 Cal. Rptr. 640, 648-51 (1986).

38. For example, current Assembly Rule 26(e) gives the Assembly Speaker power to appoint members of all committees (except the Rules Committee). CaL. Legislature HaNdbook 273 (1985 ed.). Proposition 24 assigned that authority to the two party caucuses in the assembly. CAL. Gov'T CODE $\S 9924$ (West Supp. 1986).

39. There are currently no rules or statutes, for instance, regarding the partisan composition of committees or the partisan allocation of resources.

40. San Francisco Examiner, June 10, 1984, at B1, col. 1.

41. See California Journal Ballot Proposition Analysis, supra note 19, at 143, 148 (separately paginated as 1, 6) (1984); The Legislature and Proposition 24, 15 CAL. J. 380, 381 (1984); San Francisco Chron., May 2, 1984, at 8, col. 2 (quoting one GOP legislator as confiding "If Willie was not so heavy-handed about running things, the Gann thing would not be a big deal ... . I can accept that we are the minority party but he rubs our noses in it too much."). 
minority claimed that excessive power led to such abuses as "sweetheart" consulting contracts for the Speaker's friends and manipulation of committee and bill assignments to keep certain legislation from reaching the floor. ${ }^{42}$ The "have-nots," determined to give the "haves" a taste of their own medicme, concocted Proposition 24.

The measure's nominal sponsor was Paul Gann, the conservative activist who had coauthored Proposition 13, the tax-slashing initiative, six years earher. Gann alone signed the ballot argnments supporting Proposition 24, but the initiative's true authors had been noted in the press. Assembly Republicans drafted it and spearheaded the fundraising effort that put it on the statewide ballot. ${ }^{43}$ Proposition 24's authors sought to diffuse power in the legislature by reducing the powers of the Speaker (and of the Senate President pro tempore) to essentially those of Rules Committee Chairman, by vesting both officers' former power to select committee members in the party caucuses of each chamber, by insisting that the chairpersons and vice-chairpersons of all committees be of different parties, and by requiring that committee seats and the legislature's resources be proportionately distributed between nieinbers of both parties. As an added check on the majority, the initiative required a twothirds vote for adopting each chamber's rules at the start of a session and for suspending the rules thereafter. The sponsors added a kicker at the end of the nieasure that, by itself, inay have assured electoral success: Proposition 24 saved taxpayer dollars by cutting the legislature's budget. $^{44}$

42. San Francisco Chron., May 2, 1984, at 8, col. 4.

43. San Francisco Examiner, February 12, 1984, at A1, col. 4; L.A. Times, Nov. 30, 1983, at 20, col. 1 .

44. Proposition 24 mandated an immediate reduction in the legislature's budget by thirty percent and limited future increases in its funding to the overall rate of growth in the state budget. CAL. Gov'T CODE $\$ 9934$ (West Supp. 1986). The court of appeal found this was unconstitutional because "[i]t seeks to govern the content of future legislation by limiting the amount of moneys appropriated for the support of the Legislature." People's Advocate, Inc. v. Superior Court, 181 Cal. App. 3d 316, 328, 226 Cal. Rptr. 640, 647 (1986) (einphasis in original). Such a purpose, according to the court, "runs afoul of the "familiar principle of law that no legislative board ... may divest itself or future boards of the power to enact legislation within its competence." "Id. (quoting City and County of San Francisco v. Cooper, 13 Cal. 3d 898, 929, 534 P.2d 403, 423, 120 Cal. Rptr. 707, 727 (1975)).

It is not clear how the court reached this conclusion. To be sure, the intent of Proposition 24's funding provision was to limit permanently the increases in the legislature's budgets. But Proposition 24 is only a statute and therefore not pernanent. The legislature could have amended the initiative's funding provision and thus avoided the spending cap.

There is a hitch, however. Statutory initiatives are inore difficult to amend than are laws passed by the legislature itself. Under art. II, $\S 10$ (c) of the state constitution, the legislators can only amend a statutory initiative if they have the voters' permission (in the initiative itself) or ratification by referendum. This may explain the court of appeal's conclusion that Proposition 24's funding limit unduly constrained the legislature. When the legislature enacts a inultiyear appropriation, it does not "bind" its successors because future legislatures can override this funding schedule by approving another statute with a different appropriation amount for a particular year. Such a 
Whether voters who approved Proposition 24 shared Republican legislators' discontent with the leadership in the asseinbly-and, to a much lesser extent, in the senate-is far froin certain. A Field poll conducted only three inonths before the election revealed that two thirds of the people were unaware of Proposition 24, and a third of those who did know of it had no opinion on it. ${ }^{45}$ The sane survey showed that a majority of Californians thought Willie Brown was doing a good or fair job; fewer than a fifth felt he was doing a poor one. ${ }^{46}$ On the other hand, recent political squabbles in Sacramento-ranging froin the substantive (the fight over reapportionment) to the petty (the revocation of capitol parking permits for disfavored aides to the Governor)-had been covered by the media and probably had fostered public antagonisin. The Field poll found that eighty-five percent of respondents felt "there is too inuch party pohtics in the legislature," nearly three quarters believed the legislature "spends too much money on itself," and two thirds thought that

funding adjustment is much harder to make if the legislators are trying to override a prior initiative and thus need the voters' approval.

Despite this difference between multiyear funding provisions in initiatives and in other statutes, it is still not clear that Proposition 24's funding limit is unconstitutional. In 1974, for example, voters enacted a continual appropriation as part of Proposition 9, the Political Reform Act. CAL. Gov'T CODE $\S 83122$ (West 1976). This section mandates an annual appropriation of one million dollars, adjusted for cost-of-living changes, for the Fair Political Practices Commission. The legislature has accepted the measure, adding a requirement that the Department of Finance include this amount in its annual budget bill. Id.

Beyond the precedent furnished by Proposition 9, there are other reasons for doubting the court of appeal's conclusion that Proposition 24's funding cap is impermissible. Above all, the court's objection to provisions that bind future legislatures could be extended to every statutory initiative (whether its subject is budgetary or otherwise). All initiatives constrain future legislatures precisely because the constitution requires that voters approve any amendment or repeal of that initiative.

Thus, the court of appeal's conclusion that initiatives with multiyear funding restrictions are void must rest on some constitutional infirnity that is unique to the budget process. The court did refer to the constitution's budget clause, observing that the "budget process takes special form." People's Advocate, 181 Cal. App. 3d at 328, 226 Cal. Rptr. at 647 (citing CAL. CoNST. art. IV, $\$ 12(a)$ and (c)). But its holding requires a much more specific reading of the budget clause than this. The court of appeal must read the clause to mean not only that a budget will be annually submitted to and adopted by the legislature but also that every item in these annual budgets must be free from prior constraint. While conceivable, this interpretation bears a heavy burden of persuasion in the present context where the result is to divest the voters of control over their own money. The issue of Proposition 24's funding limitation is not considered further in this Comment since it involves questions unique to the budget process, rather than the general problem of the legislaturc's autonomy.

It should be added, however, that a serious cut in the legislature's funding could so weaken the legislative power as to implicate other constitutional concerns besides the budget clause, such as the balance of powers. Since Proposition 24's initial cut in funding proved to be much less than the thirty percent reduction promised (see infra text accompanying note 54), and since its subsequent spending limits were pegged to overall increases in the state budget, the state's balance of powers was not jeopardized in this case.

45. The Field Institute, The State Legislature, CAL. OPINION INDEX, March, 1984, at 4.

46. Id. at 3 . 
body "[did] not inspire public trust and confidence."47

Public debate on Proposition 24 remained fairly sparse up to the election. Until they launclied a last-minute advertising campaign, ${ }^{48}$ Democratic leaders largely ignored the measure-thougl, when asked, they strongly denounced it as threatening legislative paralysis and ending majority rule. ${ }^{49}$ The opposition's lassitude stemmed partly from confidence that Proposition 24 would not survive a court challenge. Indeed, immediately following the election, the legislature's leadership filed an action in the state supreme court to enjom the Secretary of State from certifying the measure's passage. ${ }^{50}$ Speaker Brown announced that he would not implement the initiative's provisions (tliough they took effect inumediately) until the court adjudicated the statute's constitutionality. ${ }^{51}$ Democratic leaders were reportedly "sliocked" when, two weeks later, the court declined to interfere witlı the Secretary of State's ministerial duties. $^{52}$

While the senate implemented much of the new law fairly promptly, the assembly's compliance with Proposition 24 over the following montlis was lialting and never complete. ${ }^{53}$ A loopliole in the initiative's wording allowed the legislature to avoid a good deal of the funding reduction, though the budget was tightened in late June. ${ }^{54}$ After public

47. Id. at 2-3. Voters who resented excessive partisanship in Sacramento might have been just as likely to vote against as to support Proposition 24. See Endicott, Legislators Take the Initiative as California Partisanship Intensifies, L.A. Times, January 1, 1984, at part IV, page 2, col. 3:

[B]y their sponsorship [of Proposition 24], the GOP Assembly members have brought into sharp public focus an emerging trend in California politics-the use of plebiscitary democracy as a legislative strategy and as a weapon in the arsenal of out-of-power political parties.

$\cdots$

... [P]olitical scientists, journalists, the League of Women Voters and others have

been focusing on the exploding use of the initiative and questioning whether the process has ... fallen victim to the special interests it was created to combat.

See also D. MAGLEBY, supra note 25, at 181-84; Joint Hearings, supra note 19, at 54-55 ("The Supreme Court is put in a no-win game in which, no matter how it rules, it is certain to be criticized. ... It seems plain to me that the disease of excessive partisanship has infected the initiative process, and that the big loser, or at least $a$ big loser, is our Supreme Court.") (testimony of Professor Stolz).

48. L.A. Times, May 30, 1984, at 3, col. 2.

49. State Senator Keene, chairnan of the Judiciary Committee, declared that "perpetrators of the Gann Initiative wish to perform a political lobotomy on state government in California." Joint Hearings, supra note 19, at 59. Speaker Willie Brown asserted that if Proposition 24 passed, "The first thing you would see is the minority party being able to tie the house in knots forever." L.A. Times, May 27, 1984, at 28, col. 1.

50. San Francisco Chron., June 7, 1984, at 1, col. 5.

51. San Francisco Chron., June 8, 1984, at 1, col. 5.

52. Legislature of Cal. v. Eu, No. S.F. 24738 (Cal. Sup. Ct. June 20, 1984) (denying writ of mandamus to enjoin Secretary of State from certifying passage of initiative without prejudice to further appropriate proceedings) (reported in Cal. Official Reports, No. 20 (July 19, 1984), at 13); see San Francisco Chron., June 21, 1984, at 1, col. 1.

53. The Legislature and Proposition 24, supra note 41, at 381-83.

54. Id. at $382-83$. 
pressure for procedural compliance witl the initiative mounted over the summer, Speaker Brown unveiled a new set of assembly rules in late August that, he said, embodied the "spirit" of Proposition 24. These rules left most of the Speaker's independent authority intact. Nevertheless, many Republicans accepted the compromise and, with only four days remainimg im the session, the assembly adopted the rules. ${ }^{55}$ Finally, a private organization chaired by Paul Gann brought suit against the legislature to enforce full compliance. This action led to judicial invalidation of Proposition 24 and, im turn, spared the legislature further confrontation on this issue when it convened for the new session in December.

\section{III}

\section{The INITIATIVE Power}

Proposition 24's constitutionality depends, first, on the constitutional provisions that define the scope of statutory initiatives. ${ }^{56}$ These provisions are expansively drawn, reflecting the broad consensus that spawned the initiative power seventy-five years ago.

The sea cliange wrought by California voters in $1911^{57}$ was the culmination of a reforn movement that had been nurtured under various banners (the Good Government League, the Direct Legislation League, and the Limcoln-Roosevelt League) for some fifteen years. ${ }^{58}$ Ultimately, local successes against corruption and machine rule in Los Angeles and San Francisco emboldened a coalition of newspaper editors and independent busmesspeople to launch a statewide reform campaign, with 1 .

55. Id.; see also San Francisco Chron., Aug. 28, 1984, at 8, col. 1; id. Aug. 29, 1984, at 10, col.

56. Under the California Constitution, initiatives can either enact statutes or amend the Constitution. CAL. CoNST. art. II, $\S 8(a)$. The procedural distinction between the two types of initiatives is that the latter requires the signatures of eight percent rather than five percent of the voting electorate to secure a place on the ballot. Id. $\S 8(\mathrm{~b})$. Both constitutional and statutory initiatives, however, require only a simple majority for passage. Id. $\S 10($ a) and id. art. XVIII, $\S \S$, 4. Since Proposition 24 amended the State Government Code and not the state constitution, this Comment discusses only statutory initiatives.

The analysis that follows also considers only statewide initiatives. Judicial review of local initiatives is complicated by the need to distinguish adjudicatory, administrative, and legislative actions. Many initiatives attempting the first two types of actions havc been invalidated. For early cases articulating the problems in distinguishing local legislative initiatives, see Hopping v. Council of City of Richmond, 170 Cal. 605, 150 P. 977 (1915); Newsom v. Bd. of Supervisors, 205 Cal. 262, 270 P. 676 (1928); Simpson v. Hite, 36 Cal. 2d 125, 222 P.2d 225 (1950).

57. The Progressive legislature of 1911 submitted twenty-three constitutional amendments to the voters at the October special election. These ranged from extending the suffrage to women to permitting the recall of all elected officials. Voters approved all but one of the measures. V. KEY \& W. Crouch, The Initiative and Referendum in California $436-40$ (1939).

58. See generally G. Mowry, The California Progressives 1-149 (195I); V. Key \& W. CROUCH, supra note 57 , at $423-41$. 
Hiram Johnson as its standard bearer. ${ }^{59}$ Together, they waged a dramatic battle to wrest control of the political process from private imterests. Chief among those interests was what Governor Johnson described as "tlie former political master of this State, the Southern Pacific Company." 60

Governor Johnson took office on January 3, 1911, and on February 9 the senate adopted (by a vote of 35 to 1) a constitutional amendment authorizing initiatives and referenda. Thereafter, the assembly approved the amendment by 71 to $0 .{ }^{61} \mathrm{~A}$ spirited campaign for voter ratification followed. The ballot arguments noted that eiglit otlier states liad already adopted initiative systems, that only "special interests" opposed this plan to banislı "machine rule," and that this reform would "supplement the work of the legislature by initiating those measures whicli tlie legislature eitlier viciously or negligently fails or refuses to enact." ${ }^{.62}$ In the special election of October 1911, voters approved the amendment by a margin of roughly 170,000 to $50,000.63$

The flagrant abuses of recent legislative sessions aided Progressive candidates im making their case to the voters. Soutliern Pacific lobbyists, for exaniple, liad freely roamed the senate and assembly floors; the legislature's patronage liad reached unseemly levels. ${ }^{64}$ This does not prove, of course, that reformers imtended the initiative power to reacli the legislature's imternal conduct, but it demonstrates that they were concerned about the legislative process as well as its product. ${ }^{65}$

59. In Los Angeles, for example, a corrupt mayor resigned under the threat of recall while reformers won control of the city council. In San Francisco, a graft investigation produced over three hundred indictments and, ultimately, the conviction of the city's "boss," Abe Ruef. By the time Hiram Johnson was elected, eighteen home-rule cities in Califorma had followed Los Angeles and San Francisco in adopting initiative and referendum provisions. V. KEY \& W. CROUCH, supra note 57 , at 428.

60. Inaugural Address of Governor Hiram Johnson, reprinted in F. HICHBORN, THE STORY OF THE SESSION OF THE CALIFORNIA LEGISLATURE OF 1911, ii-n̈i app. (1911).

61. F. HichBorn, supra note 60, at 100-01; W. CROUCH, THE INITIATIVE AND REFERENDUM IN CALIFornia 4 (1950). In the 1910 session of the legislature, prior to Johnson's election, a more limited initiative amendment had failed to garner the two-thirds support needed in a 20 to 15 senate vote. F. HICHBORN, supra, at 94.

62. Gates \& Clark, Reasons Why Senate Constitutional Amendment \#22 Should Be Adopted, in Cal. Secretary of State, Proposed Amendments to the Constitution of the State of California with Legislative Reasons For and Against Adoption Thereof (October 1911).

63. V. KEY \& W. CROUCH, supra note 57 , at 440.

64. "By January 10, [1907,] the House had on its payroll thirty-six sergeants at arms, ten doorkeepers for four doors, eighteen watchmen, the same number of porters, seven postmistresses, twenty-seven engrossing and enrolhing clerks, thirty-one 'straight clerks,' and forty other people.... [One newspaper] inquired what the Southern Pacific was asking from the legislature. 'If price is any index,' it concluded, 'it should be soinething important.'" G. MowRY, supra note 58, at 63-64.

65. One other aspect of the 1911 campaign for the initiative power bears upon the courts' invalidation of Proposition 24. The 1911 reformers were keenly aware that initiatives that corrected legislative abuses might, in turn, be undone by unsympathetic courts. From a number of rulings 
As originally incorporated in article IV, section 1, the initiative amendment gave voters the power to propose and adopt "laws and amendments to the Constitution ... independent of the Legislature." The other paragraphs of the 1911 anendment set forth procedural requirements for the drafting, circulation, submission and verification of the petitions that placed initiatives on the ballot. ${ }^{67}$ The amendment stipulated that the legislature could add other procedural requirements, "in no way limiting or restricting . . . the powers herein reserved." 68 Thus, the only substantive restriction placed on initiatives was that they embody a "law" or "amendment to the constitution." 69

\section{A. The Evolving Scope of Initiatives}

The scope of the initiative power has changed little in the subsequent decades. As in most states that permit initiatives, the courts follow a prudential doctrine of hiberal construction. "The right of initiative," the California Supreme Court has declared, "is precious to the people and is one which the courts are zealous to preserve to the fullest tenable measure of spirit as well as letter."70 Within the past decade, the court has reaffinned this view: " '[I]t has long been our judicial policy to apply a hiberal construction to this power wherever it is challenged in order that the right be not iniproperly annulled. If doubts can reasonably be resolved in favor of the use of this reserve power, courts will preserve

(including decisions adverse to unions and reversals of three of the four convictions in the San Francisco graft trials), the state supreme court had become identified with the corporate interests controlling California. See G. MowRY, supra note 58, at 140-42. As a result, another constitutional amendment submitted at the October 1911 election permitted the recall of state officials, including all judges. This measure provoked controversy even in the Progressive legislature, and it became the chief target of those who opposed the reform package. See V. KeY AND W. CRouch, supra note 57, at 436-37. The amendinent's proponents nevertheless argued that, without a recall power over judges, the referendum and initiative would be "rendered valueless"-especially since "impeachment is wholly ineffective ..., only one judge ever having been removed, though several attempts have becn made under trying cases." Gates \& Clark, Reasons Why Senate Constitutional Amendment \#23 Should Be Adopted, in Cal. Secretary of State, Proposed Amendments to the CONSTITUtion of the State of CALIfornia WITH Legislative Reasons For and Against ADOPTION THEREOF (October 1911). Voters apparently shared the reformers' views of the judiciary; they approved the recall provision by an even greater margin than they gave the initiative amendment. Cal. Secretary of State, Statement of the Vote of California 5 (October 1911). Of course, this historical sidelight does not alter the constitutional scope of the initiative power. But it does suggest that courts should provide a deeper legal analysis in voiding nearly an entire initiative than they have supplied in the Proposition 24 ease.

66. CAL. Const. art. IV, $\S 1$, 1 (1911, amended 1966) (currently CAL. ConST. art. II, $\S 8(a))$.

67. CAL. Const. art. IV, $\$ 1$ (1911, amended 1966) (currently CAL. Const. art. II, $\S 10(e)$ ).

68. CAL. CoNST. art. IV, $\S 1$, \ 19 (1911, repealed 1966).

69. CaL. Const. art. IV, $\S 1, \Uparrow 1$ (1911, amended 1966) (currently CAL. Const. art. II, $\S 8(a))$.

70. McFadden v. Jordan, 32 Cal. 2d 330, 332, 196 P.2d 787, 788 (1948) cert. denied, 336 U.S. 918 (1949); see 42 Am. Jur. 2d Initiative and Referendum $\$ 5$ (1969). 
it." "71

Occasionally, such statements accompany rulings against initiatives. $^{72}$ Some commentators beheve these rulings reveal a dwindling solicitude for the initiative power. ${ }^{73}$ Over the full period since 1911, however, the court's tributes to popular sovereignty have usually proved genuine. With respect to the procedural requirements governing initiatives, the courts have developed a standard of "substantial compliance." 74 On substantive grounds, the courts have invalidated relatively few initiatives. Moreover, sucl decisions have usually been based on well-established limitations under the federal Constitution. ${ }^{75}$ Thus, the

71. Associated Home Builders, Inc. v. City of Livermore, $18 \mathrm{Cal} .3 \mathrm{~d} 582,591,557$ P.2d 473, 477, 135 Cal. Rptr. 41, 45 (1976) (quoting Mervynne v. Acker, 189 Cal. App. 2d 558, 563-64, 11 Cal. Rptr. 340, 344 (1961)).

72. E.g., Legislature of Cal. v. Deukmejian, 34 Cal. 3d 658, 669 P.2d 17, 194 Cal. Rptr. 781 (1983); McFadden v. Jordan, 32 Cal. 2d 330, 196 P.2d 787 (1948), cert. denied, 336 U.S. 918 (1949); Gage v. Jordan, 23 Cal. 2d 794, 147 P.2d 387 (1944).

73. E.g., Stolz \& Mamlet, The People v. The California Supreme Court, L.A. Daily Journal, Oct. 12, 1983, at 4, col. 3 .

74. See, e.g., Fox Bakersfield Theatre Corp. v. City of Bakersfield, 36 Cal. 2d 136, 145, 222 P.2d 879, 885 (1950) ("It has beeu repeatedly and receutly held that ... [with] an initiative ineasure where the law requires 'a title and summary of the chief purpose and points' of the measure (Cal. Const. art. IV, § 1), substantial comphiance is sufficient."); California Teachers Assn. v. Collins, 1 Cal. 2d 202, 204, 34 P.2d 134, 135 (1934) (where constitution requires that short title at the top of initiative petitions be printed in 18-point type, titles printed in 12-point type achieved "sufficiently substantial compliance"). But see Clark v. Jordan, 7 Cal. 2d 248, 60 P.2d 457 (1936); Boyd v. Jordan, 1 Cal. 2d 468, 35 P.2d 533 (1934) (failure, in both cases, to reveal in short titles of initiatives that they included a tax increase violated procedural requirements in the Political Code).

75. Of these cases, only three held that statutory initiatives were solely invalid uuder the state constitution. In Wallace v. Zinunan, $200 \mathrm{Cal}$. 585, 254 P. 946 (1927), the court found that an initiative imposing iuterest rate ceilings on certain businesses violated the single-subject rule of the state constitution. See infra text accompanying notes 76-78. In Legislature of Cal. v. Deukmejian, 34 Cal. 3d 658, 194 Cal. Rptr. 781, 669 P.2d 17 (1983), the court held that article XXI of California's Constitution prohibited an initiative proposing a second reapportionnent plan within one decade. A third decisiou, American Fed'n Labor v. Eu, 36 Cal. 3d 687, 683 P.2d 609, 206 Cal. Rptr. 89 (1984), held that a proposed initiative did not take the proper form for a law. See infra text acconipanying uotes 100-08.

In other cases, the court voided part or all of an initiative under provisions of the United States Constitution and parallel clauses in the state charter. See People v. Superior Court (Engert), 31 Cal. 3d 797, 647 P.2d 76, 183 Cal. Rptr. 800 (1982) (provision in the 1978 death-penalty initiative directing judges to choose life prison sentences or capital punishment according to the "heinous" nature of the crime was unconstitutionally vague under the fourteenth amendment's due process clause and the corresponding provisions in CAL. CoNsT. art. I, $\S \S 7(\mathrm{a}), 15)$; Hays v. Wood, 25 Cal. 3d 772, 603 P.2d 19, 160 Cal. Rptr. 102 (1979) (provision in Proposition 9, the Political Reform Act, imposing a lower business income reporting threshold for public officials who are attorneys than for those who are not violated equal proteetion under state and federal constitutions); Weaver v. Jordan, 64 Cal.2d 235, 411 P.2d 289, 49 Cal. Rptr. 537, cert. denied, 385 U.S. 844 (1966) (initiative enacted in 1964 banning pay television violated the U.S. Constitution's first amendment and corresponding provision iu California Constitutiou, CAL. ConsT. art. I, § 9).

In the remaining cases, the court invalidated parts of statutory initiatives under the federal Constitution without discussing equivalent provisions in the state charter. Three decisions, for exaniple, voided additional sections of the Politieal Reform Act under the first aniendment, explicitly following the Supreme Court's lead in Buckley v. Valeo, 424 U.S. 1 (1976). See Fair 
Progressives' broad view of the initiative power largely has been preserved.

After the initiative system was estabhished, questions naturally arose as to the status of laws enacted under it. Did their popular origin entitle them to extra deference? In 1927, the state supreme court resolved that question in the negative, rejecting in Wallace v. Zinman ${ }^{76}$ a claim that a statutory initiative " $m$ its effect is a Constitutional amendment." 77 The court stated as a general principle that initiatives were subject to the same constitutional limits as the legislature's own enactments. But the justices seemed unwilling to rest on this proposition alone. The court also explained at some length why the particular restriction at issue-the constitution's requirement that each law treat only one subject-should apply to initiatives. Simce the single-subject requirement was intended to guard against fraudulent enactments, the court concluded that the danger of fraud "obtains with like if not greater force to a measure that is to be voted upon by the people." 78 Zinman's extension of the single-subject restriction to initiatives was formally incorporated in the constitution by ainendment in $1948 .{ }^{79}$

Only three other limits have been placed on the initiative power since 1911. Each of these was iniposed by constitutional amendment and none is substantial. ${ }^{80}$ A 1946 amendment clarifies the legislature's right (jointly held with the voters) to propose amendments to previously enacted mitiatives. ${ }^{81}$ A 1950 amendment prohibits initiatives that name

Political Practices Comm'n v. Superior Court, 25 Cal. 3d 33, 599 P.2d 46, 157 Cal. Rptr. 855 (1979), cert. denied, 444 U.S. 1049 (1980) (voiding certain provisions regulating lobbyist conduct); Citizens for Jobs and Energy v. Fair Political Practices Comm'n, 16 Cal. 3d 671, 547 P.2d 1386, 129 Cal. Rptr. 106 (1976) (voiding aggregate spending limits and spending disclosure requirements imposed on supporters and opponents of ballot propositions); Hardie v. Eu, $18 \mathrm{Cal}$. 3d 371, 556 P.2d 301, 134 Cal. Rptr. 201 (1976), cert. denied, 430 U.S. 969 (1977) (voiding limits on spending for the circulation of initiative petitions). A final case voided part of an initiative, which prohibited assignment of any pupil to a public school on the basis of race, as unconstitutional under the desegregation decisions of the U.S. Supreme Court. Santa Barbara School Dist. v. Superior Court, 13 Cal. 3d 315, 530 P.2d 605, 118 Cal. Rptr. 637 (1975).

76. $200 \mathrm{Cal} .585,254$ P. 946 (1927).

77. Id. at 593, $254 \mathrm{P}$. at 949 .

78. Id. at 592, $254 \mathrm{P}$. at 949 . The omission of a key provision from the initiative's title constituted a single-subject violation under the then-existing constitutional provision mandating that "[e]very act shall embrace but one subject, which subject shall be expressed in its title." CaL. CoNST. art. IV, § 24 (amended 1966) (currently CAL. CoNST. art. IV, § 9).

79. CAL. CoNST. art. II, $\S 8(d)$. Under this provision, the single-subject rule governs constitutional amendments as well as statutory initiatives. For an operational analysis of this clause, see Lowenstein, California Initiatives and the Single-Subject Rule, 30 UCLA L. REv. 936 (1983).

80. Constitutional amendments must be approved by a majority of the voters in a state election. CAL. CoNST. art. XVIII, § 4. Proposed amendments are placed on the statewide ballot either by initiative petition, see supra note 56 , or by a two-thirds vote of each house of the legislature. CAL. CONST. art. XVIII, $\S 1$.

81. CAL. ConsT. art. II $\S 10$ (c). Such amendments proposed by the legislature to modify previously enacted statutes must still be ratified by the voters. 
individuals to a state office. ${ }^{82}$ Finally, an amendinent adopted in 1964 prohibits any initiative that confers powers or duties on particular corporations. ${ }^{83}$

Under the broad Zinman principle-that the voters' legislative power cannot be greater than the legislature's-these three restrictions should have been unnecessary. The 1950 annendinent prohibiting initiatives that appoint state officials, for example, was prompted by an earher initiative that had replaced the state Director of Public Welfare. Surely, the legislature could not have replaced a governor's appointee by statute, ${ }^{84}$ and one might have expected a suit to enforce the saine limit against the voters. ${ }^{85}$ Evidently, Zinman was seen as a single-subject rule case; its broader command of equal constitutional scrutiny for statutes and initiatives was slow to gain acceptance. Nevertheless, the Cabifornia Supreine Court recently reaffirmed the full Zinman holding, declaring that "[a] statutory imitiative is subject to the same state and federal constitutional limitations as are the Legislature and the statutes which it enacts." 86

While the court's professed standard of review thus places initiatives and other laws on an equal footing, its procedural handling of cases involving the initiative power has been deferential in one key respect. From 1949 until it enjoined a vote on a reapportionment imitiative in 1983, the court consistently rejected substantive challenges to initiative measures when they arose prior to statewide balloting. ${ }^{87}$ This reluctance to engage in preelection review appears contrary to the policy of certain constitutional provisions governing initiatives. Article II, section 8(d), for instance, states that initiatives embracing inultiple subjects "inay not be subinitted to the electors." 88 Nonetheless, preelection challenges explicitly based on this provision have been deferred for postelection

82. CAL. CONST. art. II, $\S 12$.

83. CAL. CoNST. art. II, $\S 12$.

84. See CAL. CONST. art. III, $\S 3$ (mandating separation of legislative, executive, and judicial powers); see also United States v. Lovett, 328 U.S. 303 (1946) (Congress cannot pass legislation which singles out individuals and removes them from public service); Buckley v. Valeo, 424 U.S. 1, 109-43 (1976) (Congress cannot appoint "Officers of the United States").

85. Similarly, the 1964 amendment prohibiting initiatives that favor certain corporations might have been avoided by recourse to Zinman. The 1964 amendment was intended to quash a contemporaneous initiative that sought to establish a California lottery, to be administered by a particular corporation. At the time, the California constitution prohibited the legislature from passing "special" laws, including laws "granting to any corporation, association or individual any special or exclusive right, privilege or immunity." CAL. CoNST. art. IV, § 25, I 19 (repealed 1966). Under the logic of Zinman, this clause should have voided the lottery initiative.

86. Legislature of Cal. v. Deukmejian, 34 Cal. 3d 658, 674, 669 P.2d 17, 26, 194 Cal. Rptr. 781, 790 (1983).

87. This deferential period commenced just after Perry v. Jordan, 34 Cal. 2d 87, 207 P.2d 47 (1949), where the court did reach the merits of the challenge prior to the election, but nonetheless upheld an initiative against a single-subject attack.

88. CAL. Const. art. II, §8(d). 
consideration. ${ }^{89}$

The policy of deferred adjudication miglit be justified on grounds of judicial economy; since most initiatives are defeated at the polls, the rule of postelection review avoids a good deal of adjudication altogether. ${ }^{90}$ Instead, lowever, the state supreme court has largely justified its policy as one of respect for the initiative power. ${ }^{91}$ Only four years ago, the court rejected a preelection single-subject challenge to Proposition 8, the "Victims' Bill of Riglits."92 The court was reluctant "to disrupt the electoral process by preventing the exercise of the people's franchise." 93 Even Justice Mosk, who would have taken the measure off the ballot, recognized that "the principle is firmly established that unless it is clear that a proposed imitiative is unconstitutional the courts should not interfere witl the right of the people to vote on the ineasure."94

The court's avoidance of preelection review has likely served to expand the permissible scope of the intiative power. For exainple, if a ballot proposition proves controversial during the election, the court may be more willing to believe that voter scrutiny of the initiative was sufficient to overcome single-subject objections. ${ }^{95}$ Moreover, the supreine

89. See, e.g., Brosnahan v. Eu, 31 Cal. 3d 1, 641 P.2d 200, 181 Cal. Rptr. 100 (1982) (challenge to Proposition 8, criminal reform package). The 1983 decision that broke the court's record of preelection abstention was Legislature of Cal. v. Deukmejian, 34 Cal. 3d 658, 669 P.2d 17, 194 Cal. Rptr. 781 (1983). In that case, the court kept a reapportionment initiative off the state ballot. This avoided a special election costing \$15 million as well as "very substantial problems for election officials, candidates and supporters," who faced rigid deadlines in the subsequent June primary. Id. at $666,669 \mathrm{P} .2 \mathrm{~d}$ at $21,194 \mathrm{Cal}$. Rptr. at 785 . The court also found that the initiative's unconstitutionality was "jurisdictional"- that is, it could be determined from the proposition's subject matter, "without even a cursory examination of the substance of the initiative itself." Id. at 667,669 P.2d at 21, 194 Cal. Rptr. at 785.

In its only subsequent exercise of preelection review, the supreme court followed this same dual test, but it applied the cost and "jurisdictional" criteria much more broadly. American Fed'n of Labor v. Eu, 36 Cal. 3d 687, 686 P.2d 609, 206 Cal. Rptr. 89 (1984).

90. By 1949 (the last year in which the court exercised preelection review prior to the recent Deukmejian decision), 121 initiative laws and constitutional amendments had been submitted to the voters, of which only 34 passed. W. CRouch, supra note 61 , at 42 .

Other factors which might argue in favor of postelection review include the reduced time pressures, the difference in parties, and, perhaps, the superiority of the court record in later challenges.

91. See, e.g., Schmitz v. Younger, 21 Cal. 3d 90, 92, 577 P.2d 652, 653, 145 Cal. Rptr. 517, 518 (1978) ("To preserve the full spirit of the initiative the submission of issues to the voters should not become bogged down by lengthy litigation in the courts.") (quoting Perry v. Jordan, 34 Cal. 2d 87, 91, 207 P.2d 47, 49 (1949)).

92. Brosnahan v. Eu, 31 Cal. 3d 1, 641 P.2d 200, 181 Cal. Rptr. 100 (1982).

93. Id. at 4, 641 P.2d at $201,181 \mathrm{Cal}$. Rptr. at 101.

94. Id. at 6,641 P.2d at 202, 181 Cal. Rptr. at 102 (Mosk, J., concurring and dissenting).

95. In its postelection review of recent ballot measures, the court has consistently found compliance with the single-subject rule. The court has upheld not only relatively narrow measures like 1978's tax-cutting Proposition 13, Amador Valley Joint Union High School Dist. v. State Bd. of Equalization, 22 Cal. 3d 208, 583 P.2d 128, 149 Cal. Rptr. 239 (1978), but also sprawling initiatives like Proposition 9, the Political Reform Act of 1974. Fair Political Practices Comm'n v. Superior Court, 25 Cal. 3d 33, 599 P.2d 46, 157 Cal. Rptr. 855 (1979), cert. denied, 444 U.S. 1049 (1980). 
court may feel uneasy in telling voters that a controversial ineasure they have just enacted is void. As two commentators recently noted: "No doubt the justices try their hardest to put aside the popular response to their decisions, ... . [but if] the court in the future [would] be willing to consider pre-election challenges to ballot measures, the justices [would make] it easier on themselves to decide that a proposal is imvalid.",96

Given, then, the broad original scope of the initiative power, the court's basic impulse to preserve it, and the very few restrictions that have been added to it over the years (none of which are relevant to Proposition 24), there remains ouly one factor to examine. The original and most important of the constitutional limitations on imitiatives requires that Proposition 24 embody a "law" or, in the equivalent modern phrasing, a "statute." Superficially, of course, this test is met since Proposition 24 repeals and adds several sections to the Government Code. But

When the court rejected a single-subject challenge to the encyclopedic Victims' Bill of Rights, Chief Justice Bird protested that the majority had "obliterate[d] one section of the state Constitution by effectively repealing the single-subject rule." Brosnahan v. Brown, 32 Cal. 3d 236, 262, 651 P.2d 274, 290, 186 Cal. Rptr. 30, 46 (1982) (Bird, C.J., dissenting).

The court might be expected to apply a stricter standard for single-subject compliance to initiatives than it has to the legislature's statutes; mitiatives arguably pose greater risks of uninformed voting and are more diffcult to amend in order to correct defects than are conventional laws. Indeed, former Justice Manuel suggested adoption of a tougher standard for initiatives. See Schmitz v. Younger, 21 Cal. 3d 90, 100, 577 P.2d 652, 657, 145 Cal. Rptr. 517, 522 (1978) (Manuel, J., dissenting). The court considered and rejected such arguments, however, in Fair Political Practices Comm'n, 25 Cal. 3d at 42, 599 P.2d at 51, 157 Cal. Rptr. at 860 ("Given the widespread public debate of initiatives, the explanation in the ballot pamphlets and in the media, and the huge volume of legislative business ... it is unreasonable to assume that mitiative ineasures receive less scrutiny than proposed legislation.").

96. Stolz \& Mamlet, supra note 73, at 4, col. 5. Two cases illustrate the court's careful work to preserve parts of controversial initiatives that had been approved by the voters, but that might have been invalidated on preelection review. In Santa Barbara School Dist. v. Superior Court, $13 \mathrm{Cal}$. 3d 315, 530 P.2d 605, 118 Cal. Rptr. 637 (1975), the court upheld part of an antibusing initiative because it could "conceivably be interpreted as an expression by the people of this state of their preference for a 'neighborhood school policy'. . . [that] can in no way limit or affect the constitutional obligations of school districts." Id. at 330, 530 P.2d at 617, 118 Cal. Rptr. at 649 (citation oinitted). The court exhibited a similar deference toward a constitutional amendment passed by the voters as part of Proposition 8, the Victims' Bill of Rights. In re Lance W., 37 Cal. 3d 873, 694 P.2d 744, 210 Cal. Rptr. 631 (1985). The court concluded that its own construction of the state's search and seizure clause, CAL. CoNST. art. I, $\S 13$, requirmg an exclusionary rule broader than its federal counterpart, must give way to the imitiative's requirement that "relevant evidence shall not be excluded in any criminal proceeding." In re Lance W., 37 Cal. 3d at 885-90, 694 P.2d at 751-55, 210 Cal. Rptr. 638-42 (citing CAL. ConST. art. I, § 28(d)). A vigorous dissent by Justice Mosk contended that "the voters intended no such result." In re Lance W., 37 Cal. 3d., at 899, 694 P.2d at 761, 210 Cal. Rptr. at 649 (Mosk, J., dissenting).

97. The constitution's description of the rulemaking power was amended in 1966; "the power to propose laws" (CAL. CoNST. art. IV, $\$ 1$ (1911, amended 1966)) became "the power of the electors to propose statutes" (CAL. CoNST. art. IV, $\S 22$ (currently CAL. ConST. art. II, § 8)). No change in meaning, however, was intended. See Cal. Const. Revision Comm., Proposed REVisions of the Constitution 43 (1966). 
form may not be dispositive. The issue of what constitutes a law or statute demands closer scrutiny.

\section{B. When Is a Law Not a "Law"?}

In pohtical or philosophica! discourse, "law" can signify many things. ${ }^{98}$ But its range of possible meanings is far narrower when one is determining the scope of the mitiative power. The purpose of the initiative clause, after all, is to permit public votes on "those measures which the legislature either viciously or neghigently fails or refuses to enact."99 In this context, "law" describes some subset of the legislature's own enactments.

Thus, the question that Proposition 24 poses is whether statutes that govern legislative procedure fall within or outside this category of law. The answer largely depends on whether one uses a formal or functional definition of law. As the following Sections of this Cominent demonstrate, a formal definition is easier to apply, is more congruent with the purpose of the imitiative clause, and tends to support Proposition 24's status as a "statute." By contrast, a functional defimition undermines Proposition 24's standing as a "statute." However, this functional approach creates other problems which make it less desirable as a constitutional test for what is a law.

\section{A Formal Test for Identifying Laws}

In an important decision two years ago, the California Supreme Court offered its only analysis to date of the article II, section 8 requirement that initiatives propose "statutes." In American Federation of Labor v. $E u,{ }^{100}$ the court invalidated a proposed initiative requiring the legislature to call upon Congress to approve a balanced budget amendment to the U.S. Constitution or to convene a constitutional convention for that purpose. If the legislature failed to cooperate, the proposed initiative required the Secretary of State to transmit the balanced budget resolution directly to Congress. In American Federation of Labor, the supreme court first invalidated part of the proposed initiative under article V of the Umited States Constitution, which provides that only state legislatures can apply to Congress for a constitutional convention. ${ }^{101}$

98. Professor H.L.A. Hart, for example, identifies these common issues in centuries of debate on the nature of law: "How does law differ from and how is it related to orders backed by threats? How does legal obligation differ from, and how is it related to, moral obligations? What are rules and to what extent is law an affair of rules?" H.L.A. HART, THE CONCEPT OF LAW 13 (1961).

99. See supra note 62 .

100. 36 Cal. 3d 687, 686 P.2d 609, 206 Cal. Rptr. 89 (1984).

101. The Constitution states: "The Congress ... on the Application of the Legislatures of two thirds of the several States, shall call a Convention for proposing Amendments . ..." U.S. CoNST. art. $\mathrm{V}$. 
Such applications, the court said, must issue from the legislators' "own considered judgment" and cannot be coerced by initiative. ${ }^{102}$

The American Federation of Labor court next considered whetler the proposed initiative embodied a statute, as required under the state constitution, and concluded that it did not. ${ }^{103}$ The court noted that "the reserved powers of initiative and referenduni do not encompass all possible actions of a legislative body," 104 and it mentioned several criteria which night determine when an initiative fell within the voters' domain. The court did not identify any of these criteria as decisive. On the whole, lowever, the court seemed to adopt a formal test for distinguishing pernnissible initiatives. ${ }^{105}$ The court suggested, in other words, that initiatives that take statutory form qualify as statutes while those that take the form of resolutions do not.

The court illustrated the distinction between these forms by empliasizing the differences in the legislative process. A resolution "inerely expresses the wislies of the enacting body," and "does not require the same formality of enactment [as a statute] and is not presented to the Governor for approval." 106 Surveying court opinions in otler states that had adopted systens of direct legislation, the American Federation of Labor court concluded that "the reserved power of initiative and referenduin was limited to sucli measures as constituted the exercise of legislative power to create binding law-the kind of ineasure that would be introduced by bill, duly passed by both loouses of the legislature, and presented to the governor for siguature." 107 Applymg this analysis to the balanced-budget nitiative before it, the American Federation of Labor court concluded that the proposition did not qualify as a statute because it enibodied

in part a simple declaration of policy, without statutory implementation,

102. American Fed'n of Labor, 36 Cal. 3d at 706, 686 P.2d at 622, 206 Cal. Rptr. at 102.

103. The American Fed'n of Labor court found only one California precedent which had any bearing on the art. II, $\S 8$ requirement that initiatives propose "statutes." In an early case, Hopping v. Council of City of Richmond, $170 \mathrm{Cal} .605,150 \mathrm{P} .977$ (1915), the supreme court had upheld a municipal referendum which sought to overturn a city council action. The American Fed'n of Labor court noted that, although the council had acted by resolution, its decision (establishing the site of a new city hall) was "an exercise of legislative power ... [and thus] subject to referendum." $36 \mathrm{Cal}$. 3d at 710, 686 P.2d at 624, 206 Cal. Rptr. at 104. But the American Fed'n of Labor court did not appear to extend the principle of Hopping - that the form of a resolution might cloak a law-to the statewide level. The justices pointed out that art. IV, $\S 8$ of California's constitution prevents the legislature from enacting laws by resolution. Id. at 708-09, 686 P.2d at 623, 206 Cal. Rptr. at 103. Moreover, a legislature's laws and resolutions are procedurally distinguishable (by the governor's participation), whercas a city council's may not be.

104. Id. at 708, 686 P.2d at 623, 206 Cal. Rptr. at 103.

105. The court was not consistent in following this formal test. See infra note 140 and accompanying text.

106. Id. at 708-09, 686 P.2d at 623, 206 Cal. Rptr. at 103.

107. Id. at 711, 686 P.2d at 625-26, 206 Cal. Rptr. at 105-06. 
and in part a step in a federal process which may eventually lead to amendment of the federal Constitution. It does not create law and thus, under the authorities and analysis we have exainined, does not "adopt" a "statute" within the Ineaning of article II of the California Constitution. ${ }^{108}$

What result emerges when this same analysis is applied to Proposition 24? It appears that the initiative meets the American Federation of Labor court's criteria for "creating law." The initiative takes the form of amending the State Government Code. It parallels many laws that the legislature has itself enacted, governing most aspects of the legislature's internal organization. ${ }^{109}$ Moreover, no principle appears to deterinine whether particular internal matters can be dealt with by statute, instead of rule. ${ }^{110}$ From this perspective, if the initiative process is co-extensive with the legislature's lawmaking authority, Proposition 24 would appear to address issues within the ambit of the initiative power.

\section{The Amendability of Procedural Statutes}

It is sometinies clainied, however, that rules adopted by a single chamber, and without presentment to the governor, can supersede previously enacted statutes goverming the legislature's internal functions. Under this view, procedural statutes stand on an entirely different footing from conventional statutes because they can be overridden by rules.

108. Id. at 714, 686 P.2d at 627-28, 206 Cal. Rptr. at 107-08 (emphasis added).

109. Prior to Proposition 24, those matters treated under various sections of the Government Code included: the initial procedure for organizing each senate and assembly session, CAL. Gov'T CODE $\S \S 9022,9023$ (West 1980), the timing of oaths administered to members, id $\S 9024$, the method of appointing committee members of standing committees, $i d . \S 9026$, requirements for open meetings and executive sessions (both in chambers and in committees), id. $\$ \S 9027-9031$, creation of several joint committees, id. $\S \S 8940-8955$ (Joint Ethics Committee), $\$ 9107$ (Joint Rules Committee), $\S \S 9140-9146$ (Joint Budget Committee), designation of senate and assembly officers and their mode of selection, id. $\$ \S 9170-9173$, those officers' duties, $i d . \$ \S 9190-9196$, the code of ethics governing legislators, $i d$. $\$ \S 8920-8922$, and compensation and reimbursement schedules for legislators, id. $\$ \S 8901-8903$.

110. In one of its trial court briefs in the Proposition 24 litigation, the California Senate contended that "the vast majority of" the legislature's rulemaking statutes are confined to six distinct categories. Senate Defendants' Reply to Plaintiff' Opposition to Motion for Judgment on the Pleadings at 4, n.5, People's Advocate, Inc. v. California Legislature, No. 324211 (Sacramento County Super. Ct., Dec. 11, 1984). Except for one of these categories, however, the senate defendants failed to offer any principle that would explain why these areas of legislative procedure, but not others, should be governed by statutes rather than rules. (The one exception is those Government Code sections which provide for legislative organization prior to each session's adoption of rules.)

The senate defendants attempted to distinguish statutes creating legislative committees as being necessary "to provide for the committees' continuing existence between sessions of the Legislature." Id. This statement is misleading since, at the time these statutes were enacted, the constitution expressly gave the legislature the power to establish such pernianent committees by unicameral or concurrent resolutions. CAL. CONST. art. IV, $\S 11$ (1940, repealed in part 1972); see supra note 6. The legislature itself secured the repeal of this rulemaking power from the Constitution. See CAL. SECRETARY OF STATE, AMENDMENTS To CONSTITUTION 12 (November 1972). 
Indeed, the court of appeal in the Proposition 24 case stated that "[a] rule of internal proceeding made in the guise of a statute is nonetheless a rule 'adopted' by the house and nay be changed by an internal rule."111 An early adherent of this view was Luther Stearns Cushing, the nineteenth-century American parhamentary authority whose treatise on legislative practice was adopted by California's second constitutional convention as its own rules of proceeding. ${ }^{112}$ Cushing asserted that

[t]he principle, that each branch of a legislative assembly has a right to determine its own rules, is deemed so important that where it is inserted in the constitution of a State, it has been doubted whether it was competent for the legislature of such State by law to provide rules for the government of its respective branches which should bind them and supersede their authority to make rules for themselves. ${ }^{113}$

To the extent that Cushing described a parliamentary norni-the principle that each legislative session ought to enjoy procedural autonomy-the questions raised by his commentary must be deferred to this Comment's later discussion of the rulemaking clause. ${ }^{114}$ For the moment, the issue is a narrow one: Does Proposition 24 qualify as a "statute" or is it only a "rule"? In answering this question, the key inquiry is whether Cushing's treatise correctly describes the status of procedural laws in California. Prior to the court of appeal's decision in the Proposition 24 case, no California court had ever evaluated Cushing's priniciple that procedural rules displace prior statutes. ${ }^{115}$

Mason's Manual, ${ }^{116}$ a inodern parliamentary handbook which the California Assennbly and Senate now use as their procedural authority, ${ }^{117}$ preserves Cushing's view. Mason's Manual asserts that "the house and

111. People's Advocate, Inc. v. Superior Court, 181 Cal. App. 3d 316, 326, 226 Cal. Rptr. 640, 646 (1986) (emphasis in original).

112. 1 Debates and Proceedings of the Constitutional Convention of the State of CALIForNIA 73 (1880) (hereinafter cited as 1879 DeBATES). California's first constitutional convention-the one that placed the rulemaking clause in the state constitution-adopted Thomas Jefferson's Manual of Parliamentary Practice as its rules of proceedings. REPORT OF THE DEBATES in the Convention of California on the Formation of the State Constitution 19 (1850) (hereinafter cited as 1849 DEBATES). Jefferson's manual might have given California's framers a different perspective on the rulemaking power. See infra text accompanying notes 204, 303-05.

113. L. Cushing, Elements of the Law and Practice of Legislative assemblies in THE United States of America 247 (2d ed. Boston 1866) (1st ed. Boston 1856) (footnote oinitted). See also Joint Hearings, supra note 19, at 45 (testimony of Professor Post).

114. See infra Part IV.

115. The courts inight not rely on legislative habit to determine whether the legislature can replace laws with rules. As the United States Supreme Court stated when it invalidated Congress' use of the legislative veto, the fact that such a veto mechanism was embedded in over 200 federal statutes "will not save it if it is contrary to the Constitution." INS v. Chadha, 462 U.S. 919,944 (1983).

116. P. Mason, Manual of Legislative Procedure (1979).

117. Cal. Assembly R. 10. Significantly, this rule stipulates that Mason's Manual is the authority "[i]n all cases not provided for by the Constitution, by the Assembly Rules, by the Joint 
senate inay pass an internal operating rule for its [sic] own procedure that is in conflict with a statute formerly adopted."118 Only one case, however, is cited for this proposition: a decision by the Georgia Supreine Court that provides weak authority for Mason's principle. ${ }^{119}$ In Cahfornia, the evidence that subsequently adopted rules override procedural statutes is sparse. ${ }^{120}$ In its Proposition 24 decision, the court of appeal noted two circuinstances where the legislature essentially amended a procedural law by implementing a subsequent and conflicting rule. ${ }^{121}$ In both cases, the legislature adopted rules, governing the structure or procedure of a committee, that displaced a prior statute. ${ }^{122}$

Assuming the court is correct that, in these two instances, one or both houses consciously niodified a procedural statute by adopting a conflicting rule, there are still many nore occasions when the legislature has amended these laws by statute. This would scarcely be necessary if a unicanieral resolution could achieve the saine purpose. The arguinent that California's procedural statutes give way to subsequent rules is further weakened when one compares the California Legislature's mode of rulemaking to that of the United States Congress.

Durmg the past fifteen years, both the House and Senate have found it necessary to enact statutory schemes involving matters of internal procedure. For example, the Congressional Budget Act of 1974 establishes House and Senate Budget Committees and detailed timetables for development and consideration of annual budget resolutions. ${ }^{123}$ However, at

Rules of the Senate and Assembly, or by statute." (emphasis added). Senate Rule 20 is similarly worded.

118. P. MASON, supra note 116, at 3, 2.

119. Coggin v. Davey, $233 \mathrm{Ga} .407,211$ S.E.2d 708 (1975). In Coggin, the court was forced to determine whether Georgia's ambiguously phrased "sunshine law" (requiring open meetings) applied to the state legislature or only to the executive branch. Since the house and senate had subsequently passed their own rules for executive sessions, the court inferred from this that the legislature did not intend to subject itself to the earlier "sunshine law." Id. at 410-11, 211 S.E. 2d at 710-11. Thus, while the court described the rules as "inconsistent" with the sunshine law, there was no real conflict between rule and statute.

120. One incident illustrates just how weak the evidence for Mason's principle is. When the Chairman of the State Senate's Judiciary Committee and the Minority Leader of the Assembly were confronted with Cushing's text, they seemed startled to learn that the procedural statutes their respective bodies had jointly enacted had no more permanence than, and could be superseded by, a unicameral rule. See Joint Hearings, supra note 19, at 45.49 (testimony of Professor Post).

121. People's Advoeate, Inc. v. Superior Court, 181 Cal. App. 3d at 326 n.11, 226 Cal. Rptr. at $646 \mathrm{n} .11$. In one of its appellate briefs, the legislature noted two other, similar circumstances where rules had superseded statutes. Returu of Real Parties in Interest Legislature and Joint Rules Committee to Alternative Writ of Mandate at 13-14, People's Advocate, Inc. v. Superior Court, 181 Cal. App. 3d 316, 226 Cal. Rptr. 640 (1986).

122. It is not clear in either of these cases that the legislators who follow the rule recognize that there is a conflicting statute. Moreover, rules that establish committees enjoy a special constitutional status under art. IV, $\S 11$. The purpose of that clause was to place rules that establish committees on a par with statutes. See supra notes 6, 110 .

123. 2 U.S.C. $\$ 621$ et seq. (1982). 
least in the House (which, like the California Assembly and Senate, is not a continuous body ${ }^{124}$ ), these procedural provisions in the Budget Act are treated as lapsing at the end of each Congress, along with other House rules. Thus, the resolution establishing rules of the House at the beginning of a Congress typically stipulates "[t]hat the rules of the House of Representatives of the [previous] Congress, including all applicable provisions of law, and concurrent resolutions adopted pursuant thereto ... are hereby adopted as the rules of the House of Representatives of the [current] Congress, with the following amendments."125 More importantly, the Budget Act itself contains two clauses in whicli the Senate and House have underscored the impernianent nature of statutory provisions related to procedure. Such statutes

are enacted by the Congress (1) as an exercise of the rulemaking power of the House of Representatives and the Senate, respectively ... and (2) with full recognition of the constitutional right of either House to change such rules (so far as relating to such House) at any time, in the same manner, and to the same extent as in the case of any other rule of such House. ${ }^{126}$

The Cahifornia Senate and Assembly liave not taken any comparable steps to limit the effectiveness of their statutory rules. The resolution establishing the assembly's Standing Rules at the outset of a session, ${ }^{127}$ for exainple, does not purport to reinstate statutory provisions which inight have lapsed with adjournment. ${ }^{128}$ Nor does any section of the Governinent Code qualify all of its provisions as being subject to preeinption by either house's rulemaking prerogative. Soine statutory sections stipulate a particular practice in the legislature "if [a] house by resolution or its rules does not direct otherwise." 129 But this suggests, if anything, that other sections of the Government Code are not subject to the same proviso. ${ }^{130}$

124. See Swing v. Riley, 13 Cal. 2d 513, 517, 90 P.2d 313, 315 (1939) (neither the assembly nor the senate is a continuous body: "[S]ince fifty percent of the senate membership at each regular session is newly elected, there is not present [following sine die adjournment] a 'majority' of the membership of the body ....").

125. E.g., 129 CoNG. REc. H5 (daily ed. Jan. 3, 1983) (emphasis added).

126. 2 U.S.C. $\$ 621$ note (1974). Similar language is included in the Legislative Reorganization Act of 1970, Pub. L. No. 91-510, § 101, 84 Stat. 1140, 1143.

127. See, e.g., J. OF THE ASSEMBLy, Dec. 6, 1982, at 8-45.

128. However, the rules do recoguize statutes as one source of parliamentary authority. See supra note 117.

129. E.g., CAL. Gov'T CODE $\S 9026$ (West 1980) (providing that committees will be appointed by the presiding officer in each chamber).

130. Similarly, art. IV, $\S 7$ (c) of the state constitution requires the legislature's proceedings to be public, "except as provided by statute or by concurrent resolution," and then adds that, "if there is a conflict between such a statute and concurrent resolution, the last adopted shall prevail." CAL. ConsT. art. IV, $\S 7(\mathrm{c})$. This final sentence would be unnecessary if subsequent rules automatically preempted prior statutes. 
It seenis probable, then, that unicameral rules do not supersede ruleniaking statutes in California. If that is true, such statutes enjoy the same pernianence as other laws, which augments Proposition 24's claim to constitutionality. If a rulenaking law is just like any other law, then it ineets the article II, section 8 requirenent that mitiatives embody "statutes."

Nevertheless, this conclusion is not essential to upholding the new initiative. If, instead, the court of appeal in the Proposition 24 case was correct-if rulemaking statutes inust give way to subsequent unicaineral rules-Proposition 24 inay yet qualify as a statute under article II, section 8. After all, the legislature treats procedural statutes as binding laws, at least until they are superseded by conflictmg rules. In these circunistances, the question of Proposition 24's constitutional sufficiency as a statute sinuply shifts to different ground. Constitutionality now hinges on a single clause in the new initiative: the clause that restricts the legislature's power to amend Proposition 24.

\section{Permitting Unicameral Amendments to Proposition 24}

A crucial clause in Proposition 24 provides two mechanisms by which the legislature can ainend the new initiative. First, the legislature can enact niodifications "only to further [the Proposition's] purposes" by a two-thirds inargin in both chambers, with the governor's approval. ${ }^{131}$ Secondly, the legislature can change Proposition 24 in any way it wishes, providing that the voters ratify the change in a statewide referendum. ${ }^{132}$ The initiative further provides that if the first of these nuechanisnis for ainendnient is invalidated by the courts, the second will be the "exclusive ineans of ainending or repealing" the new law. ${ }^{133}$

If rulemaking statutes inust be susceptible of amendment by unicaineral rules, it is clear that these two restrictive modes of amending Proposition 24 cannot stand. Since the initiative does contain a standard severability clause, ${ }^{134}$ the sections limiting Proposition 24's amendment can be excised. This severance, however, may not suffice. A complication arises because the state constitution prohibits the legislature from amending any statute enacted by initiative without the voters' permission (or subsequent approval). ${ }^{135}$ Thus, in order for Proposition 24 to be constitutional, the legislature would have to be able to annend it by unicaneral rule and the voters would have to pernit such amendment.

131. Cal. Gov't CoDE § 9904(a) (West Supp. 1986).

132. Cal. Gov't CoDE § 9904(b) (West Supp. 1986).

133. CAL. Gov't CODE $\S 9904$ (West Supp. 1986).

134. CAL. Gov't CoDE $\S 9906$ (West Supp. 1986). It seems clear that the provisions limiting Propositions 24's ameudment would be severable under the current standards for severability. See infra note 375 .

135. Cal. CONST. art. II, § 10(c). 
Obviously, Proposition 24 does not furnish such permissionindeed, it expressly provides two contrary modes of amendment. Therefore, after excising the two clauses that limit amendments, a court would have to infer from Proposition 24's severability language that the voters permit the legislature to amend the new law by unicameral rule. The severability clause states that when a provision in the initiative is invalidated, the remainder will be sustained, "to the extent it can be given effect."136 A court would have to read into this general language the voters' permission for unicameral amendments to the initiative.

In previous cases, the California Supreme Court has resisted such rewriting of statutes to preserve their constitutionality. ${ }^{137}$ In those precedents, however, the court balked primarily at the difficulty of the task. Rewriting the law in a way that faithfully reflected legislative intent yet ensured constitutionality was a daunting prospect. ${ }^{138}$ By contrast, that task is fairly easy in the case of Proposition 24. There should be hittle question that the voters would rather have Proposition 24's "reforms" iniposed on the legislature, even if these would then be subject to amendment by unicameral rules, than have the entire initiative scuttled. Such determinations of alternative legislative intent carry great weight in decisions involving severability. ${ }^{139}$

By invalidating the clause im Proposition 24 that restricts the legisla-

136. CAL. Gov'T CoDE $\S 9906$ (West Supp. 1986).

137. See, e.g., Metromedia, Inc. v. City of San Diego, 32 Cal. 3d 180, 649 P.2d 902, 185 Cal. Rptr. 260 (1982) (declining to rewrite local billboard ordinance); Blair v. Pitchess, 5 Cal. 3d 258, 486 P.2d 1242, 96 Cal. Rptr. 42 (1971) (constitutionality of claim and delivery statute could uot be saved by rewriting it); Seaboard Acceptance Corp. v. Shay, 214 Cal. 361, 365, 5 P.2d 882, 884 (1931) (court lacked power to rewrite law regulating conditional sales contracts "so as to make it conform to a presumed intention which is not expressed").

138. The Metromedia court, for example, contemplated reworking an antibillboard ordinance so that it would only apply to commercial messages, in conformity with first amendment law. The court concluded that such "drastic surgery" would create a law that was hard to administer and probably would not serve the ordinance's purpose. $32 \mathrm{Cal}$. 3d at 190, 649 P.2d at 908, $185 \mathrm{Cal}$. Rptr. at 266. Similarly, the Blair court conceded that a claim and delivery law might be implemented without violating the fourth and fifth amendments. Yet, the court held that "[i]f the scope of a statute cannot be limited to situations to which it may constitutionally apply except 'by reading into it numerous qualifications and exceptions' amounting 'to a wholesale rewriting of the provision,' the statute cannot be saved by judicial construction." 5 Cal. 3d at 282, 486 P.2d at 1259, 96 Cal. Rptr. at 59 (quotiug Fort v. Civil Service Comm'n, 61 Cal. 2d 331, 340, 392 P.2d 385, 390, 38 Cal. Rptr. $625,630(1964))$.

139. See, e.g., Metromedia, Inc. v. City of San Diego, 32 Cal. 3d at 189, 649 P.2d at 908, 185 Cal. Rptr. at 266 ("even if the statute following severability is not what the enacting body originally intended, the courts can sustain the statute if severance is mechanically feasible and the legislative body would have preferred such an outcome to total invalidation"). It might be argued that the task of inferring the people's consent (that is, their consent that Proposition 24 should be amendable by rules) is more a question of statutory construction than severability. The Metromedia court suggested that judges were not as frec to implement alternative legislative intent when they were interpreting statutes, rather than severing them. Id. However, once the clause that limits the legislators' power of amendment is excised from Propositiou 24, there is nothing left to interpret in the initiative on the subject of ameudability. It is as if Proposition 24 had becn silent on the matter 
ture's power of amendment, a court could sustain the rest of the initiative while holding this new law subject to amendment by senate or assembly rules. A contrary result-a court ruling that Proposition 24 cannot be amended by rules (and is thus wholly invalid) simply because it does not expressly so provide-would be far less faithful to the constitution's provisions governing initiatives. After all, the purpose of the constitution's clause forbidding amendment of initiatives without the voters' consent is to strengthen the people's initiative power as against the legislature. The result would be paradoxical indeed if the legislators could invoke the same clause to defeat an initiative. The legislators would be insisting, in effect, that they cannot constitutionally be given the power to amend Proposition 24 by rules.

The foregoing analysis suggests that Proposition 24 does qualify as a "statute" under the California constitution. Given the number of procedural statutes in California, the usual practice of amending those laws by statute, the paucity of clear conflicts between these laws and the legislature's rules, the lack of judicial authority attributing inferior status to such laws, and the initial presumption that all statutes have equal force, it is reasonable to conclude that the regulation of internal procedure is within the California Legislature's lawmaking power. Even if procedural laws must give way to subsequently adopted rules, they are valid statutes nonetheless. It follows from the supreme court's analysis in American Federation of Labor that Proposition 24 does "create a law." The measure thus fulfills the requirement, under article II, section 8 of the state constitution, that an initiative adopt a "statute."

Still, doubts inay linger about this conclusion. One difficulty is that the American Federation of Labor court did not state that its reliance on forn to distinguish statutes was definitive. That test suited the court's purposes well in the factual setting of American Federation of Labor; it disposed of an initiative which made no pretense of being a statute. At some poimts in its opinion, however, the American Federation of Labor court edged toward a functional test for distinguishing non-statutes. ${ }^{140}$ In voiding Proposition 24, the court of appeal unequivocally adopted a functional test. The court declared that "the subject of statutory laws

from the outset. Thus, the need to consider alternative intent results from severing, rather than interpreting, the new initiative.

140. For example, the American Fed'n of Labor court quoted Judge Sutherland to the effect that "by "law" is meant those legislative actions which operate on all persons in society, and must be enforced by the executive department, and sustained by the judiciary.' "American Fed' $n$ Labor, 36 Cal. 3d 687 at 709, 686 P.2d 609 at 624, 206 Cal. Rptr. 89 at 104 (quoting 1A SuTHERLAND, STATUTORY CONSTRUCTION 335 (Sands rev. ed. 1972)). At another point, the court returned to this functional view: a resolution, "as distinct from a statute, is essentially an enactment which only declares a public purpose and does not establish means to accomplish that purpose." $36 \mathrm{Cal}$. 3d at 712 n.23, 686 P.2d at 626 n.23, 206 Cal. Rptr.at 106 n.23. 
and rules of internal proceedings categorically differ" ${ }^{141}$ and that "[i]t is not the form by which the rule is adopted but its substance which measures its place in the constitutional scheme."142 The court's explanation of the substantive difference between rules and statutes, however, was not very satisfying. For the most part, the court simply reiterated that "the subjects of statutes are laws"143 and that "rules of proceeding ... are the exclusive prerogative of '[e]ach house' of the Legislature." 144 Such statements tended to assume the distmction that was being explained. At two points in its opimion, however, the court of appeal rehed on specific functional criteria to distinguish rules from statutes: (1) the difference between internally and externally apphed rules and (2) the distinction between binding and nonbinding rules. A close examination of these distinctions will illustrate the problems in adopting substantive rather than formal criteria for separating laws from rules. ${ }^{145}$

\section{A Functional Test for Distinguishing Laws from Rules}

The court of appeal first asserted that "[t]he kinds of rules and primciples which are subsumed under the statutory 'law' are addressed to the world outside the legislature,"146 citing the United States Supreme Court's decision in INS v. Chadha ${ }^{147}$ The reference to Chadha seeins inappropriate since that decision had nothing to do with the rulemaking authority. Indeed, Chadha rejected a congressional claim of unicameral power. The Court held that so-called "legislative vetoes," whereby one chanber of the Congress often overruled actions of executive agencies, were unconstitutional. Such vetoes, the Court found, could only be achieved through the bicameral legislative process mandated under article I, section 7 of the Uinted States Constitution. ${ }^{148}$

The court of appeal's rehiance on Chadha for its internal/external distinction between laws and rules was also misplaced. The veto challenged in Chadha had overturned a stay of deportation. The Supreine Court described the reinstatement of an ahen's deportation as having

141. People's Advocate, Inc. v. Superior Court, 181 Cal. App. 3d 316, 325, 226 Cal. Rptr. 640, 645 (1986) (emphasis in original).

142. Id. at $327,226 \mathrm{Cal}$. Rptr. at 646.

143. Id. at 325, 226 Cal. Rptr. at 645 .

144. Id.

145. In relying on these operational distinctions between rules and laws, the court of appeal echoed the opinion of the Massachusetts Supreme Judicial Court in Paisner v. Attorney General, 390 Mass. 593, 458 N.E. 2d 734 (1983). The Paisner court invalidated a "legislative reform" initiative very similar to Proposition 24, before it was placed on the state ballot. Apparently, Paisner is the only other case in which a court has confronted the power of initiatives to govern legislative procedure.

146. People's Advocate, 181 Cal. App. 3d at 325, 226 Cal. Rptr. at 645 (emphasis in original).

147. 462 U.S. 919 (1983).

148. Id. at 952 . 
"the purpose and effect of altering the legal rights, duties and relations of persons, ... all outside the Legislative Branch."149 Apparently, the court of appeal in the Proposition 24 case took this to mean that legislative actions which do not have such effects "outside the Legislative branch" are not laws at all. But, the Chadha Court's point was only that legislative actions whose effects are "outside the Legislative branch" exceed the House or Senate's umicaneral authority.

Regardless of whether the California court of appeal drew legitinate support from Chadha for its internal/external distinction between statutes and rules, the distinction itself poses difficulties in practice. One problem is deciding what to make of the numerous statutes governing legislative procedure that the legislature has already enacted. The court of appeal dismissed these statutes as an "apparent anounaly," 150 finding "no reasons why this practice is legally significant."151 Yet, the court's conclusion was at least as anomalous as the legislature's practice. The court of appeal found that all such statutes were in fact only rules, "notwithstanding [their] means of adoption or label,"152 and it even suggested that the state constitution does not authorize the use of statutes to estabhsh legislative procedure. ${ }^{153}$ This extreme reading of the constitution is unwarranted. ${ }^{154}$

A more serious problem with the court of appeal's internal/external

149. Id.

150. People's Advocate, Inc. v. Superior Court, 181 Cal. App. 3d at 326, 226 Cal. Rptr. at 646.

151. Id.

152. Id. at 327, $226 \mathrm{Cal}$. Rptr. at 646 . On this point, the court of appeal quoted directly from the Massachusetts Supreme Judicial Court's opinion in Paisner v. Attorney General, 390 Mass. 593, 458 N.E. 2d 734 (1983) (see supra note 145). According to both courts, "[t]he enactment of statutes relating to internal proceedings was obviously accomplished by the voluntary participation of each of the two Houses. Thus, each House was essentially engaged in its rule-making function." People's Advocate, 181 Cal. App. 3d at 326-27, 226 Cal. Rptr. at 646 (quoting Paisner, 458 N.E. 2d at 739. 40).

153. People's Advocate, 181 Cal. App. 3d at 326, 226 Cal. Rptr. at 646 . The court of appeal based this finding on the clause in the state constitution that requires open meetings of the legislature "except as provided by statute or by concurrent resolution ... adopted by two-thirds vote." CAL. CONST. art. IV, $\S 7(\mathrm{c})$. Noting that " $[\mathrm{t}] \mathrm{his}$ is the only constitutional provision that authorizes the statutory control of a rule or resolution of internal proceeding ...," the court of appeal found an "unmistakable implication ... that none other was intended." People's Advocate, 181 Cal. App. 3d at 326, 226 Cal. Rptr. at $645-46$ (emphasis in original).

154. "[R]estrictions and linitations [imposed by the Constitution] are to be construed strictly, and are not to be extended to include matters not covered by the language used." Methodist Hosp. v. Saylor, 5 Cal. 3d 685, 691, 488 P.2d 161, 165, 97 Cal. Rptr. 1, 5 (1971). If strictly construed, art. IV, $\S 7(\mathrm{c})$ of the state constitution (see supra note 153) does not imply a sweeping ban on the procedural use of statutes. Rather, that clause appears to contemplate the use of both statutes and rules to govern legislative procedure. After all, the purpose of this recently adopted constitutional clause was not to permit the legislators to do something otherwise forbidden. The intention was to make it more difficult for the legislature to close its meetings by requiring that closed sessions be effected pursuant to statutes (or resolutions supported by two-thirds votes) rather than under unicameral rules. See California Secretary of State, California Voters Pamphlet 25 (June 1974). 
distinction between rules and laws is that it provides no basis for determining how far initiatives may intrude into the legislature's realm. How, for example, would a court classify a "sunshine law" (requiring open meetings of the legislature) under the new interual/external taxonomy? Applying the court of appeal's description of statutes (measures which "are addressed to the world outside the legislature") it is difficult to say that a sunshine law einbodies a statute. Yet it is equally difficult to explain why such a measure should not fall within the voters' doinain. Indeed, the court of appeal faced this very issue in the Proposition 24 case and sidestepped the question. As noted previously, the reform initiative provided for public notice of all meetings of the senate and assembly (and of their committees) and strictly limited the occasions for executive sessions. ${ }^{155}$ The court of appeal held ouly that these open meeting provisions were severable from the rest of Proposition 24 and expressly reserved judgment on their constitutionahity. ${ }^{156}$

The court's internal/external distinction between rules and statutes creates probleins even beyond Proposition 24. For example, it is not at all clear how section 89001 of the Califorma Government Code would fare under the court's test. That code section prohibits legislators from sending out newsletters at public expense once they have declared their candidacy for reelection. The section was enacted as part of Proposition 9, the political reform initiative approved by the voters in $1974 .{ }^{157} \mathrm{~A}$ court inight well conclude that this restriction on legislators' use of newsletters is not a measure "addressed to the world outside the legislature" and thus is not a proper statute. Such results discredit this internal/ external test as a workable guideline.

The court of appeal's opinion in the Proposition 24 case rehed upon one other criterion for separating rules from laws. The court suggested that rules are less binding than statutes, quoting dicta from a turn-of-thecentury opinion by the Califorma Supreme Court to this effect: "A house "has power to adopt any procedure and to change it at any tinie and without notice. It cannot tie its own hands by establishing rules which, as a inatter of power purely, it cannot at any time change or disregard." "158 As the final words in this passage indicate, the supreine court conflated two principles, at least one of which was not correct. A legislative body is not free to "disregard" its rules unless what the supreine

155. CAL. Gov'T CODE $\S \S 9926-28$ (West Snpp. 1980); see supra notes $29 \& 37$ and accompanying text.

156. People's Advocate, Inc. v. Superior Court, 181 Cal. App. 3d at 330 n.14, 226 Cal. Rptr. at 648 n.14.

157. CAL. Gov'T CODE $\S 89001$ (West I976).

158. People's Advocate, Inc. v. Superior Court, 181 Cal. App. 3d at 327, 226 Cal. Rptr. at 646 (quoting French v. Senate, 146 Cal. 604, 608, 80 P. 1031, 1033 (1905)). The dicta in French is further explained infra note 176. 
court meant was that often no legal consequences will issue if the rule is disobeyed. Under doctrines of abstention and jurisdiction, courts usually decline to enforce legislatures' internal rules. ${ }^{159}$ Nevertheless, in cases where private parties' rights are at issue, courts have made it clear that legislatures' rules are legally binding. ${ }^{160}$

The supreme court's more fundamental point, in the turn-of-thecentury decision just quoted, was that the procedural rules of a house must, by their nature, be susceptible of change by that body. For the court of appeal in the Proposition 24 case, this seemed to be a decisive reason for distinguishing rules from laws and for invalidating the new initiative. The court emphasized the continuous power of a house to control its own proceedings and asserted that "[n]either house of the Legislature may bind its own hands or those of future legislatures by adopting rules not capable of change."161 Thus, the court of appeal seemed to be troubled by the same aspect of Proposition 24 that troubled Professor Robert Post: "[I]t is binding the Legislature in a way that it cannot bind itself." 162

Care must be taken in interpreting this objection. For to say that the voters can do something by initiative that the legislature cannot do merely describes a constitutional truth. As has already been noted, article II, section 8 of the California constitution provides that laws enacted by initiative possess an extra measure of durability. Such laws may only be amended by the legislature with the voters' permission or concurrence. ${ }^{163}$ Clearly, the legislature by itself cannot enact laws of such pernianence.

159. See, e.g., State v. Cumberland Club, 136 Tenn. 84, 91-92, 188 S.W. 583, 585 (1916) ("The Senate has the right, under the Constitution to make its own rules . . . and it must be the judge of those rules. All the court can do is to ascertain whether the Constitution has been complied with."); State v. Savings Bank, 79 Conn. 141, 152, 64 A. 5, 9-10 (1906) ("[I]t would be an unwarranted invasion of the independence of the legislative department for the court to set aside [an] action as void because it may think that the House has misconstrued or departed from its own rules of proceeding."); see also State ex rel. Todd v. Essling, 268 Minn. 151, 169-75, 128 N.W.2d 307, 319-23 (1964) (Nelson, J., concurring) and the numerous cases cited therein.

160. See, e.g., Yellin v. United States, 374 U.S. 109, 121 (1963) (witness who had been denied opportunity to testify in executive session before House Un-American Aetivities Committee was "entitled to have the Committee follow its rules and give him consideration aceording to the standards it ha[d] adopted" for executive sessions); United States v. Smith, 286 U.S. 6 (1932) (rejecting Senate's construction of its own rules; expedited notification to the President that his nominee had been confirmed precluded Senate's reconsideration of its vote). Thus, Yellin and Smith repudiate the claim that a legisiature can disregard its own rules. Indeed, in the Proposition 24 case, the court of appeal acknowledged that internal rules "may bind the house which adopted them." People's Advocate, Inc. v. Superior Court, 181 Cal. App. 3d at 325, 226 Cal. Rptr. at 645. See also INS v. Chadha, 462 U.S. at 956 n.19 (rulemaking clause empowers Congress to "act in legally binding manner").

161. People's Advocate, Inc. v. Superior Court, 181 Cal. App. 3d at 328, 226 Cal. Rptr. at 647.

162. Christian Science Monitor, June 11, 1984, at 6, col. 3.

163. Proposition 24 does provide for limited amendments by the legislature without voter ratification. See supra text accompanying note 131. But this provision is not discussed separately in the analysis that follows because it still "binds the legislature in a way that it cannot bind itself." 
While in one sense it is true, therefore, that the voters' and the legislature's lawinaking powers are coextensive, it is also true that the initiative power dilutes the legislature's power. Once the voters, by statutory initiative, have put in place a program or policy, that particular matter is withdrawn from the range of subjects that the legislators are free to address on their own.

Thus, the fact that an initiative "binds the Legislature in a way that it cannot bind itself" need not inıpair its constitutional validity. And, while a rulemaking statute passed by initiative thus has more permanence than the saine statute enacted by the legislature, this does not mean that it constrains legislators beyond what is already contemplated under the imitiative system. Even if a court found that rulemaking statutes are the sort of laws that must be amendable by unicameral rules, the court could modify a rulemaking initiative so that it is susceptible of change by one house of the legislature. ${ }^{164}$

\section{Moving Beyond Proposition 24's Sufficiency as a "Statute"}

Ultinnately, then, the objection to Proposition 24 on grounds that it binds the legislature must mask other concerns. In the first place, binding the legislature is a time-honored feature of the initiative process and, in the second place, the binding quality of a rulemaking statute can be judicially remedied if, in fact, the constitutional status of the rulemaking process so requires. Hence, the objection inust be to the voters' enactment of procedural rules in the first place-quite apart from the legislature's ability to amend them. This objection no longer rests upon hinitations implicit in the constitution's initiative clause-limitations involving the legal requirements for "statutes." Rather, the objection rehes upon the constitution's rulemaking clause to inipose an external check on the initiative power.

At the heart of this objection to mitiatives that enact legislative rules is a special concern about procedural autonomy. Indeed, this formed the core of the court of appeal's decision in the Proposition 24 case. The court began its opinion by quoting extensive dicta about the rulemaking prerogative from a Cahforma Supreme Court opinion of more than a century ago:

A legislative assembly, when established, becomes vested with all the powers and privileges which are necessary and incidental to a free and unobstructed exercise of its appropriate functions. These powers and privileges are derived not from the Constitution; on the contrary, they arise from the very creation of a legislative body and are founded on the principle of self preservation. ${ }^{165}$

164. See supra text accompanying notes 134-139.

165. People's Advocate, Inc. v. Superior Court, 181 Cal. App. 3d at 322, 226 Cal. Rptr. at 643 
Under this view of legislative power, the rulemaking clause reflects a deliberative body's need for procedural flexibility. This is the view that the court of appeal embraced in voiding Proposition 24. "Since the mception of our state," the court proclaimed, "the power of a legislative body to govern its own internal workings lias been viewed as essential to its functioning . . . ."166

If the court of appeal is right about this interpretation of the rulemaking clause, then article IV, section 7 of California's constitution could indeed impose an external restramt on the imitiative power. But the court's interpretation of the rulemaking clause is only one of several that are possible. Moreover, the court's construction rests largely on assumptions about the origins and meaning of the rulemaking clause.

These historical assumptions liave been clear at every stage of the Proposition 24 litigation. One of the senate's trial briefs, for example, claimed that the "statutory initiative cannot withdraw that whicl centuries of parliamentary democracy and the express language of the Califorma Constitution have granted." 167 The rulemaking clause, according to the senators, reflects "centuries of parliamentary law regarding the exclusive power of eitlier house of a legislature to govern itself." 168 The senate brief then erroneously cited Thomas Jefferson as liaving written that laws cannot bind the procedure of a legislature. ${ }^{169}$ An appellate brief from the assembly reprised the basic theme: "Every western parliainentary body has inherent powers that derive froin centuries of law, tradition, and practice." 170

It is scarcely surprising that the trial judge who voided Proposition 24 invoked the Federalist Papers in expounding California's rulemaking clause. ${ }^{171}$ The court of appeal enlarged this historical view, claiming that "[t]he powers challenged by [Proposition 24] are deeply rooted in constitutional soil."172 The court found that "the power of a house of the Legislature ... to "establish its own rules of proceedimg" " had been "an

(quoting Ex parte D.O. McCarthy, 29 Cal. 395, 403 (1866)). For further analysis of the dicta in McCarthy, see infra note 176.

166. People's Advocate, $181 \mathrm{Cal}$. App. 3d at 322, $226 \mathrm{Cal}$. Rptr. at 643 (emphasis added).

167. Senate Defendant's Reply to Plaintiff's Opposition to Motion for Judgment on the Pleadings at 2, People's Advocate, Inc. v. California Legislature, No. 324211 (Sacramento County Super. Ct., Dec. 11, 1984).

168. Id. at 7 .

169. Id. at 7-8. What was attributed to Jefferson is actually a modern annotation of his Manual of Parliamentary Practice which summarizes parliamentary rulings by Speakers of the House. See the edition of Jefferson's Manual in H.R. Doc. No. 374, 88th Cong. 2d Sess. 176 (1965).

170. Memorandum of Assembly Real Parties In Opposition to Petition for Writ of Mandate and Return To Petition for Writ of Mandate at 10, People's Advocate, Inc. v. Superior Court, 181 Cal. App. 3d 316, 226 Cal. Rptr. 640 (1986).

171. See supra text accompanying note 12.

172. People's Advocate, Inc. v. Superior Court, 181 Cal. App. 3d at 322, 226 Cal. Rptr. at 643. 
integral part of . . parliamentary common law."173 California's constitution, the court concluded, "was enacted by the people agamst [this] history of parliamentary common law. That law is implicit in the Constitution's structure ...."174

Given the influence tliat this presumed history of the rulemaking clause exerts, the presumption warrants careful investigation. Accordingly, the next Part of this Comment examines the clause's origins. This interpretivist enterprise, lowever, inust be kept in perspective. The discussion below delves considerably into California, colonial, and Britisl history to discover possible meanings of the ruleinaking clause. The risk in this approacl is that it creates expectations that "the initent of the framers" can be discovered and that this intent alone will resolve Propositions 24's constitutionality. In fact, as Part IV of this Comment demonstrates, the original purpose of California's ruleniaking clause remams uncertain. The California Legislature's arguinents in the Proposition 24 litigation are troubling precisely because tliey erroneously imply that "centuries of parliamentary law" reveal a clear, original intent underlying the rulemaking clause.

In addition, even if we could know the intent of those who framed California's rulemaking clause (or the rulemaking clauses of earlier constitutions), this would not dispose of the clause's meaning in the twentietli century. Professor John Hart Ely's observation about the federal Constitution applies witl equal force to California's charter: it is "a legal docuinent to be imterpreted ... in accord witl its language and purpose. . . . [The] specific implications for each age were meant to be interpreted in contemporary context."175 Parts IV and V of this Comment lieed Professor Ely's counsel-examining, first, the purposes of the rulemaking clause and then assessing their implications for the modern age.

Part IV looks at plausible purposes. A review of the political conditions at the time that California's first constitution and its colomal precursors were drafted reveals several functions that the clause niay liave served. In a sense, this amounts to speculating about various "intents of the framers." Where possible, lowever, the analysis resists the language of intent.

A focus upon intent could confuse two distinct concepts: the framers' purpose in drafting a rulemaking clause and their likely views on whetlier voters should legislate procedural rules. Constitutional drafters of the eigliteentli and nineteentlı century imglit well have balked at the

173. Id. at 323, $226 \mathrm{Cal}$. Rptr. at 643 .

174. Id. at $322,226 \mathrm{Cal}$. Rptr. at 643.

175. Ely, Constitutional Interpretivism: Its Allure and Impossibility, 53 IND. L.J. 399, 400 (1978). 
voters' exercise of rulemaking powers. But such attitudes are relevant to the present inquiry only if they informed the framers' drafting of a rulemaking clause. A further reason for avoiding the language of intent is that intent tends to be conceived of as unitary, whereas the rulemaking clause may have served multiple purposes. The uncertainty of the historical evidence also counsels against choosing one interpretation of the clause.

Part V shifts the analysis to the modern context. Each of the rulemaking clause's plausible functions is examined within the framework of California's present government-that is, a state political structure which includes the initiative power. This approach affords a comprehensive assessment of whether the rulemaking clause limits the initiative power.

Prior to the invalidation of Proposition 24, no California court had ever been required to determine the rulemaking clause's function or to define its scope. As already noted, two early opinions by the California Supreme Court described the rulemaking power in sweeping ternis, and the court of appeal relied on that dicta in voiding Proposition $24 .{ }^{176}$

176. French v. Senate, 146 Cal. 604, 80 P. 1031 (1905); Ex parte D.O. McCarthy, 29 Cal. 395 (1866); see supra notes 158 \& 165 and accompanying text. In McCarthy, the court rejected the habeas corpus petition of a newspaper editor who had been imprisoned by the senate. The editor had published allegations of bribery against unnamed senators but, when called to testify before the senate, declined to answer its questions. The court expounded at some length upon the inherent powers of the senate, see supra text accompanying note 165 , but ultimately acknowledged that the editor's imprisonment had been effected under a statute aimed at compelling witnesses' testimony "which entirely covers this case." McCarthy, 29 Cal. at 406. Thus, no senate rules were at issue.

In French, the California Supreme Court upheld the senate's two-thirds vote to expel some of its members for bribery. At that time, the rulemaking authority and the right of expulsion were joined in the same clause of the constitution, former CAL. CoNST. art. IV, $\S 9$, and thus the court's description of the legislature's inherent power which sustained "this provision", French, $146 \mathrm{Cal}$. at 606,80 P. at 1032, referred only to the second half of the constitutional clause, the expulsion power, although the full clause was quoted. See supra text accompanying note 7.

The language in McCarthy and French regarding the rnlemaking power is not only dicta but also reflects an era when courts were far more deferential to legislatures' actions than is the case today. Thus, the actual holdings in McCarthy and French are of doubtful modern authority. In French, for example, the expelled senators sought a ruling from the court that they had been improperly excluded without a hearing on, or a chance to defend against, the bribery charges. Id. at 605,80 P. at 1032. A modern court would surely uphold such a claim. See McCarley v. Sanders, 309 F. Supp. 8 (M.D. Ala. 1970) (expulsion of Alabama state senator, after he was denied, inter alia, the right to cross-examine witnesses against him, voided as a denial of due process).

In $M c$ Carthy, the court held that a legislature that refuses to hear a contumacious witness " "by counsel before adjudging him in contempt might have acted arbitrarily and improperly. . . . [Y] was a matter resting solely in the discretion of that body.'" 29 Cal. at 400 (quoting Falvey and Kilbourn v. Massing, 7 Wis. 630,639 (1858)). The vitality of this holding today is questionable. See In re Batelle, 207 Cal. 227, 253, 277 P. 725, 735-36 (1929) ("[T] he power of the statc senatc to adjudge [witnesses] to be guilty of contempt and to order . . . their confinement is a power which can only be exercised in strict conformity with the rules of procedure which the laws of this state provide . . .."). See also Groppi v. Lesile, 404 U.S. 496 (1971) ("[T]he Constitution imposes no general barriers" to legislative punishment of contemptuous conduct, id. at 499, but essential elements of due 
Aside from those distant pronouncements, however, the functional analysis of the rulemaking clause in Parts IV and V begins on a clean slate.

\section{IV}

\section{THE RulEMAKING AUTHORITY}

At first glance, the rulennaking clause in California's constitution seems to diverge significantly from its federal counterpart. Article I, section 5 of the United States Constitution, providing that "[e]ach House may determine the Rules of its Proceedings," seems permissive. Article IV, section 7(a) of California's charter, stipulating that "[e]ach House shall ... adopt rules for its proceedings," appears to enjoin the legislature to fulfill a duty. The use of "adopt" rather than "determine" in the California clause is a recent change and has no significance. ${ }^{177}$ But there is still the difference between "shall determine" and "n1ay determine." Is this dissimilarity intentional or important? History suggests it is neither.

\section{A. Tracing the Origins of California's Rulemaking Clause}

The 1849 convention at Monterey which produced California's first constitution was a hurried but purposeful affair. Congress had failed to provide a civilian government for California, after the territory was taken in the Mexican-American War. The Monterey delegates were thus impatient to fornulate a plan of government. ${ }^{178}$ The convention met in early September 1849 , lacking a printing press to aid the drafting process and hampered by language barriers because sonie delegates spoke only Spanish. The result was a frankly plagiarized document, assenibled and approved in a mere forty days. While such issues as state boundaries and slavery generated protracted debate, there was hittle discussion of the mechanical aspects of government. Indeed, the dyspeptic Mr. Botts, a delegate fron Monterey, assailed the blatant borrowing from other states' constitutions:

[G]entlemen on this floor [should] remember that they are no longer citizens of New York, or Missouri, Iowa, or Michigan, but citizens of California ... [and should] not make a constitution like an old woman's spencer-composed of shreds and patches.... [L]et there be at least one

process must be followed and, in general, "the legislative contempt power should be limited to "[t]he least possible power adequate to the end proposed' [citations omitted]." Id. at 506.)

177. In proposing this change, the California Constitutional Revision Commission explained that "[t]hroughout Article IV the language was rephrased in more modern, clear, and concise phraseology." CAL. CONST. Revision COMM., supra note 97, at 24.

178. See Proclamation of the Governor, Recommending the Formation of a State Constitution, or a Plan of a Territorial Government (June 3, 1849), reprinted in 1849 DEBATES, supra note 112, at 3.

For additional background on the 1849 convention, see H. BANCROFT, 6 HISTORY OF California 251-307 (1888); R. Hunt, The Genesis of California's First Constitution 2051 (1895); W. Palmer \& P. Selvin, The Development of LaW in California 2-17 (1983). 
original section in the Constiution [sic]. ${ }^{179}$

The most frequent references during the debates were to the constitutions of New York and Iowa, which had been enacted in 1846 and 1848, respectively. ${ }^{180}$

The article dealing with the legislature was the third part of the constitution to be reported to the convention floor. The convention debated and approved its thirty sections in one day. There was no discussion of the provision for each house's rulemaking power. ${ }^{181}$ The exact wording of the rulemaking provision offered in the convention was contained in New York's constitution, where it had first appeared in 1821, and this fact may well settle the California clause's provenance. ${ }^{182}$ Yet, the delegates at Monterey could easily have found their inspiration elsewhere.

Most state constitutions, including those of nearly all the original states, contamed unicameral rulemaking clauses very similar in wording to California's clause. Some states followed the federal model, providing that each house "may determine" its rules. ${ }^{183}$ Other charters declared that each house "shall settle" its rules. ${ }^{184}$ Still other constitutions foreshadowed the "shall determine" language that prevailed in California. ${ }^{185}$ There does not seem to be any significance to these variations; each was adopted by different states during roughly the same period. ${ }^{186}$ It is reasonable to conclude, then, that the rulemaking clauses in the federal and state constitutions of the post-Revolution period were born of the same impulses. ${ }^{187}$

179. 1849 DEBATES, supra note 112 , at 51 .

180. Bancroft observed that "there was a good deal of 'slavish copying' of the constitutions of New York and Iowa." H. BANCROFT, supra note 178, at 296.

181. 1849 DEBATES, supra note 112 , at 76-94.

182. N.Y. CoNST. of 1821 , art. I, $\$ 3$. Twelvc of the forty-eight delegates at Montercy were born in New York. The six native Californians comprised the next largest contingent (all of whom were Hispanic). See H. BANCROFT, supra note 178, at 288.

183. E.g., PA. Const. of 1790 , art. I, $\S$ XIII7; DeL. Const. of 1792 , art. II, $\S 7$; and KY. CoNST. of 1792, art. I, 19.

184. E.g., MD. CoNST. of $1776, \S 24$; GA. ConsT. of $1777, \S 24 ;$ N.H. ConsT. of 1783 , Pt. 2 , art. 22; and VA. CONST. of 1830 , art. III, $\S 9$.

185. E.g., S.C. ConsT. of 1790 , art. I, $\S 12$; CoNN. ConsT. of 1818 , art. III, $\S 8$; N.Y. ConsT. of 1821 , art. I, \& 3 .

186. The "each House shall settle" construction might be read as the most permissivc of the three; it could signify an adjudicatory right of legislative bodies, suggesting freedom from interference by another chamber or branch of government. Yet, to this day, the Massachusetts Constitution provides that its senate "shall ... determine its own rules of proceeding" while its house "shall settle the rules and orders of proceeding." MASS. CONST. pt. 2, ch. 1, § 2, art. 7, and id. pt. 2, ch. 1, $\S 3$, art. 10. Barring a dichotomized view of the General Court's rulemaking poiver, these semantic variations seem insignificant.

187. Despite the similar phrasing, these clauses may takc on different meanings at the federal and state level, particularly when an initiative power is added by the states. Such differences, however, would arise from the differing level of government, not the clauses' language. The important factor for the moment is that the rulemaking clauses at both the federal and state level seem to have had a common origin. 
What, then, were the rationales for these rulemaking clauses? Virginia's constitution was the first state charter to incorporate a rulemaking clause. Unfortunately, nothing that is known of that constitution's origins clearly reveals the clause's meaning. ${ }^{188}$ By late 1775 , a state convention, structured much like the Virginia House of Burgesses and coinprisimg most of its leaders, had effectively becoine the government in Virginia. In May 1776, having instructed its delegates to the Continental Congress to support a move for colonial independence, the convention appointed a committee to formulate a new plan of state government. ${ }^{189}$ In the draft constitution reported by this committee to the convention, the rulemaking power was subsumed under a provision involving the assembly's elections: "Let the right of suffrage ... remain as exercised at present and let each house settle its own rules of proceding, [and] direct writs of election for supplying intermediate vacancies." 190 At soine point during the full convention's debate on the draft, the right of each house to "choose its own Speaker [and] appoint its own Officers" was inserted in this clause. ${ }^{191}$ In that form, the clause was adopted with the rest of the new constitution on June 29, 1776. Since we have no account of the committee's deliberations and only a summary description of the convention's proceedings, ${ }^{192}$ there is no firm basis for determining what the members had in mind when they fashioned this rulemaking language.

The debates of the federal constitutional convention in 1787 shed no further light on the rulemaking clause's origins. None of the plans put forward when the delegates first convened in Philadelphia exphicitly provided for Congress's rulernaking authority. ${ }^{193}$ Ultimately, the Philadel-

188. For analysis of the Virginia constitution and its genesis, see C. LINGLEY, THE Transformation in Virginia From Colony to Commonwealth 21-177 (1910); A. Nevins, The AMERICAN STATEs DuRING AND AFTER THE Revolution, 1775-1789, at 27-29, 117-25, 14348 (1924); 1 The PaPers of George Mason 295-98 (R. Rutland ed. 1970); Morey, The First State Constitutions, 4 ANNALS 201 (1893).

189. Several proposals for state government were available to this drafting committee, including an "aristocratic" plan, 6 AM. Archives 748-54 (Ser. 4 1846), attributed to Carter Braxton (see C. LINGLEX, supra note 188, at 170), a draft froin John Adams, 4 C. ADAMS, THE WORKS OF JOHN ADAMS 193-200 (1865), three versions of a plan by Thomas Jefferson, 1 THE PAPERS OF THOMAS JEFFERSON 337-65 (J. Boyd ed. 1950) [hereinafter cited as JEFFERSON PAPERS], and a coinprehensive proposal drafted by George Mason, see id. at 366-73. None of these plans contained a rulemaking clause.

190. JEFFERSON PAPERS, supra note 189, at 370.

191. Id. at 380 .

192. Proceedings of the Convention of Delegates Held at the Capitol in the City of WilliamsBurg, MaY 6TH, 1776, at 66, 77-78 (1816).

193. One scholar has suggested that the clause was simply lifted from state constitutions. D. Hutchison, The Foundations of ThE Constitution 64 (1975). The draft constitution offered by Charles Pinckney of South Carohina specified several of the internal powers ultimately granted to Congress (including the right to choose its own officers), but it did not provide a general ruleinaking power. $1 \mathrm{~J}$. Madison, Journal of THE Debates in the Convention Which Framed the CONSTITUTION OF THE UNITED STATES 19-31 (G. Hunt ed. 1908). Alexander Hamilton's draft enumerated similar privileges. J. MAdISON, Notes of DEBATES IN THE Federal CONVENTION 
phia convention produced its draft constitution from a series of general propositions submitted by Edmund Randolph and his fellow Virginians, ${ }^{194}$ which were gradually refined during weeks of debate and then submitted to a Committee of Detail. It was the Committee of Detail that added the provision that "[e]ach House may determime the rules of its proceedings." 195 According to James Madison's notes, the full convention adopted this clause without discussion. ${ }^{196}$ Thus, the rulemaking clause did not figure prominently in the constitutional scheme. ${ }^{197}$

\section{B. The British Tradition of Parliamentary Autonomy}

It is tempting to assume that the colomial framers drew directly upon rights established by the British Parliament when draftimg these clauses in the new American constitutions. But, of course, there was no written constitution in England. Although there were recorded precedents for soine of the pariamentary privileges recognized by the colonial framers, apparently none of these encompassed an explicit principle of rulemaking autonomy. ${ }^{198}$ As Blackstone wrote, "the maxims upon which [the Lords and Commons] proceed, together with their inethod of proceeding, rest entirely in the breast of the parliainent itself; and are not defined and ascertained by any particular stated laws."199

Blackstone and a later historian did suggest that the procedural autonoiny of the Lords and Commons was recoguized before the eighteenth century. ${ }^{200}$ But even assuming that the colomists drew upon this

OF 1787, at 138 (Ohio University Press ed. 1960) [hereinafter cited as 1787 DEBATES]. The New Jersey delegation suggested revisions in the Articles of Confederatiou, id. at 118-21, which themselves lacked any provision for the rulemakiug authority of the Continental Congress. ARTICLES OF CONFEDERATION, art. IX, 7.

194. 1787 DEBATES, supra note 193 , at 30.

195. Id. at 388 .

196. Id. at 431.

197. Nor was the ruleinakiug provision discussed by any of the antifederalists during ratification. See 1 The CoMPLETE ANTI-FEDERALIST 112 (H. Storing ed. 1981). The absence of debate on the rulemaking clause during the Philadelphia Convention was scarcely unique. Delegates approved without debate inost of the other clauses specifying each house's prerogatives. See 1787 DeBATES, supra note 193, at 414 (U.S. CoNST. art. I, § 2, cl. 5); id. at 423 (U.S. CoNST. art. I, § 3, cl. 5); id. at 431 (U.S. CoNST. art. I, § 5, cl. 1 and art. I, § 6, cl. 1).

198. See infra note 203.

199. 1 W. Blackstone, Commentaries *159.

200. Id. at *158; 2 J. Redlich, The Procedure of The House of Commons 7 n. 1 (A. Steinthal trans. 1908). Both Blackstone and Redlich founded their claims on a statement by Sir Edward Coke that "whatever matter arises concerning either house of parliament, ought to be examined, discussed, and adjudged in that house to which it relates, and not elsewhere." W. BLACKSTONE, supra note 199 , at * 158 .

Whatever Lord Coke meant by this statement, he could only have embraced in a normative sense the modern view of procedural autouomy. During Coke's life, the crown controlled the designation of the Speaker of the Commons and, in turn, the Speaker controlled a great deal of the Commons's procedure, including its order of business. 4 W. HOLDSWORTH, A HisTORY OF ENGLISH LAW 97, 176 (3d ed. 1924). Indced, during the reign of Elizabeth I, a fundamental dispute 
British tradition, it is not clear what principles motivated the American rulemaking clauses. Did the framers behieve that deliberative bodies required procedural autonomy to fulfill their legislative functions? Or did the rulemaking clauses answer other purposes? On this issue, England's parliamentary historians contribute little. It is not particularly lelpful, then, to speculate on the foreign inspiration for article I, section 5 of the American Constitution.

Nevertheless, one general point can be made about the colonists' perception of their parliamentary heritage. They probably recognized that the House of Commons' rules liad been "worked out, so to speak, as the procedure of an opposition."201 Originally, that opposition was between Crown and Parliament. The English Bill of Riglts, for example, which summarized Parliament's conditions for offering the Crown to William and Mary im 1689, had specified that "the freedom of speech, and debates or proceedings im parliament, ought not to be impeached or questioned im any court or place out of Parliament." ${ }^{202}$ John Hatsell's definitive volume on the privileges of the Commons, published in 1776, recounted a long succession of pohtical conflicts between Crown and Commons, embodying the relentless shift of power from sovereign to aristocracy in the post-Tudor age. ${ }^{203}$ Thomas Jefferson, who relied considerably on Hatsell in compiling his own Manual of Parliamentary Practice, echoed this view of the evolution of privileges: "Claims seem to have been brouglit forward from time to time, and repeated till some example of their admission enabled them to build a law on that example."204

By the eighteenth century the locus of this "opposition" lad shifted. The conflict was now played out between the Prime Minister and the minority im Commons, but rules and privileges still seem to have been at issue. ${ }^{205}$ Hatsell quoted Artluur Onlsow, who liad been Speaker of the House of Commons for thirty-five years, on this very point: "[N]othing tended more to throw power into the hands of administration, and those

persisted over Parliament's right to discuss matters not submitted by the Crown, the Queen asserting that no monarch "fit for his state will suffer such absurdities." Id. at 90.

201. I J. REDL1CH, supra note 200 , at 57 (emphasis in original).

202. 1 W. \& M., Sess. 2, ch. 2 (1689).

203. I J. Hatsell, Precedents of Proceedings in the House of Commons (3d ed. 1796). Hatsell was Clerk of the House of Commons. His volume on privileges did not discuss procedural autonomy as such, and thus autonomy may not have been considered a privilege in its own right. But the principles of autonomy and privilege were closely bound together. For example, the right to determine the order of its own business was one of the "privileges" the Commons asserted even before the English Civil War. Id. at 79. As Professor Holdsworth observed: "It was the privileges of the House which enabled it to ... carry on the controversy with the king in a Parliamentary way." $6 \mathrm{~W}$. HOLDSWORTH, supra note 200 , at 92.

204. T. Jefferson, Manual of Parliamentary Practice vi, 15 (1854).

205. See C. Friedrich, Constitutional Government and Democracy 328-29 (4th ed. 1968). 
who acted with the majority of the House of Commons, than a neglect of, or departure from, the rules of proceeding."206 Indeed, the Crown's and the Prime Minister's interference with Parliament's proceedings-especially the bribery of members with places and pensions-in order to suppress opposition became the subject of frequent, sometimes violent, denunciations by England's "Old Whig" leaders. ${ }^{207}$

Long before the American Revolution, colomial legislatures strove to emulate Parhiament's mdependence. The lower houses in America presumed they were "equivalents of the House of Commons and must perforce in their limited spheres be entitled to all the privileges possessed by that body in Great Britain." ${ }^{208}$ Colonial representatives drew on that logic "to mcrease their authority at the expense of both the colonial executives and the London government."209 Moreover, in the years preceding the Revolution, American colonists avidly followed the escalating attacks on the corruption of Parliament. Professor Bernard Bailyn has noted that the British "opposition press, as much as any single influence, ... shaped the political awareness of eighteenth-century Americans." Chief among the "attitudes and ideas that would constitute the Revolutionary ideology ... were the fear of corruption-of its anticonstitutional destructiveness-and of the menace of a ministerial conspiracy."211

\section{American Doctrines That Shaped the Rulemaking Clause}

Thus, to the extent that events in Britain influenced the colonists' thinking about legislative procedure, the effect was probably to augment concern about the balance of powers, rather than to inspire appreciation for the functional value of procedural autonomy. At most, however, what went on in London could only have formed a backdrop to the colonists' own experiences. Colonial leaders, after all, liad practiced government themselves, and their poitical thinking was well-developed by 1776. Whicl of their own political doctrimes supported the drafting of rulemaking clauses? Two primciples suggest themselves: the separation of powers and bicaneralisin. Each of these primciples formed a common thread in the political debates of the Revolutionary era.

206. T. JEFFERSON, supra note 204, at 13 (citing Hatsel1).

207. See B. Bailyn, The Ideological Origins of the American Revolution 34-54 (1967); C. ROBBINS, THE EIGHTEENTH-CENTURY COMMONWEALTHMAN 284-88, 356-77, 381-82 (1961).

208. J. Greene, The Quest for Power: The Lower Houses of Assembly in the SOUTHERn RoYal Colonies, 1689-1776, at 15 (1972). As in the House of Commons, one of the first standing committees established by the Virgima Burgesses, and by most other colonies' lower houses, was a Committee on Privileges and Elections. R. HARLow, THE History OF LEgisLative METHODS IN THE PERIOD BEFORE 1825, at 11 (1917).

209. J. GREENE, supra note 208, at 1.

210. B. Bailyn, The Origins of American Politics 38-39 (1968).

211. B. BAILYN, supra note 207, at 144. 
Volumes have been written on these doctrines, and a review of that scholarship would be impossible here. It is possible, however, to illustrate in a general fashion how these two principles might have led the colonial framers to develop a rulenaking clause. After considering the clause's intellectual provenance, this Comment will examine whether the clause prevents voters froin structuring legislative procedure. As that analysis will show, if the rulemaking clause does reflect concerns about separation of powers or bicameralism, then it nay still conflict with Proposition 24. That conflict, however, will be far less clear than the courts have supposed and will require a deeper analysis than they have offered.

\section{Separation of Powers}

The eighteenth century conception of the separation of powers was not monohthic. In his detailed study of the doctrine's developinent prior to 1787 , W. B. Gwyn identifies at least five (often intermingled) versions offered by various commentators. ${ }^{212}$ They beheved that separated powers served

(1) to create greater governmental efficiency; (2) to assure that statutory law is made in the common interest; (3) to assure that the law is impartially administered and that all administrators are under the law; (4) to allow the people's representatives to call executive officials to account for the abuse of their power; and (5) to establish a balance of governmental powers. ${ }^{213}$

A common principle umited these theories. As Gwyn observes, "[a]11 but the efficiency version [were] directly concerned with the mamtenance of civil hiberty and the avoidance of tyranny."214

In practice, it appeared that tyranny could be forestalled in two related ways, as Madison implied in the Federalist Papers. On the one hand, no department should "possess, directly or indirectly, an overruling influence over the others in the administration of their respective powers."215 This might be thought of as a negative approach to the separation of powers; the aim is to restrict the right of any branch to exercise powers beyond its appropriate sphere of activity. On the other hand,

212. W. GWyn, The Meaning of the Separation of Powers 126-28 (1965).

213. Id. at 127-28 (footnote omitted).

214. Id. at 128. Gwyn traces the efficiency argument, one of the earliest versions of the doctrine, to Marchamont Nedham, who observed in 1656 that certain duties required the secrecy and dispatch that ministers (but not deliberative bodies) could provide. Id. at 32 (citing $\mathrm{M}$. Nedham, The Excellencie of a Free-State: OR, The Right Constrtution of a CommonWEALTH 99-100 (1656)). Forty-five years later, John Locke offered a different version of the efficiency rationale: lawmaking could be accomphished in short periods of time, but execution of the laws required constant supervision and hence a separate branch of government. W. GWYN, supra note 212, at 77 (citing J. LOCKE, THE SECOND TREATISE OF GOVERNMENT (1690)).

215. The FederalisT No. 48, at 308 (J. Madison) (C. Rossiter ed. 1961). 
"the great security ... consists in giving to those who administer each department the necessary constitutional means and personal motives to resist encroachments of the others."216 This might be called an affirmative view of the separation of powers, since its approach is to strengthen each department internally so that it can stand up to external challenges.

The rulemaking clause could have furthered the separation of powers $m$ both the negative and affirmative sense. In the negative sense, the clause prevented the executive from interfering with the legislature's internal affairs. In the affirmative sense, it pernnitted the legislative branch to proceed im whatever way it wished, to assert itself most effectively within the government. This affirnative approach to separating powers might more properly be described as a shift in the balance of powers toward the representative branch, and it will be labeled this way in the following discussion.

A "negative" intention behind the rulemaking clause would have been especially understandable at the state level. Prior to Independence, colonial governors had exercised stronger executive powers over legislative bodies than the King had claimed over Parliament. ${ }^{217}$ As Professor Gordon Wood observes, Americans at the beginning of the Revolution thought of the separation of powers primarily im terins of "insulating the judiciary and particularly the legislature from executive manipulation." 218 The result was that

[t]he state constitutions of 1776 explicitly granted the legislatures not only tasks that they lad claimed with varying degrees of success in the course of the eighteenth century but also functions that in the English constitutional tradition could in no way be justified as anything but executive, such as the proroguing and adjourning of the assembly, the declaring of war and peace, the conduct of foreign relations, and in several cases the exclusive right of pardon. ${ }^{219}$

Nowhere was this shift in power toward the legislature more strikmg than in Virginia's constitution - the same charter that apparently spawned the rulemaking clause. As Jefferson later explained that consti-

216. The Federalist No. 51, at 321-22 (J. Madison) (C. Rossiter ed. 1961).

217. B. BaILYN, supra note 210 , at 67 . These extra powers included the right of veto and "suspension" against legislation, unlimited right to prorogue or dissolve the legislature, and the right to dismiss judges and create courts without statutes. In theory, the British Crown retained the right to reject Parliament's laws, but this veto was never exercised after 1707. Id. at 67-68.

218. G. Wood, The Creation of the AMERICAN Republic 157 (1969).

219. Id. at 155. For discussion of the theoretical dimensions of the new state constitutions, see J. Pole, Political Representation in England and the Origins of the american Republic 169-338 (1971); Buel, Democracy and the American Revolution: A Frame of Reference, 21 WM. \& MARY Q. (3D SERIES) 165 (1964); Webster, Comparative Study of the State Constitutions of the American Revolution, 9 ANNALs 380 (1897); Wright, The Early History of Written Constitutions in America, in EsSAYS IN History AND Political THEORY IN HONOR OF C.H. MCILWAiN 344 (1936). 
tution's manifest imbalance: "The abuses of monarchy had so filled our minds that we imagined everything republican that was not monarchy."220 The new charter reduced the governor to hittle more than an administrative figurehead, selected annually by the senate and the house, whose sole authority was "with the advice of a Council of State, [to] exercise the executive powers of government, according to the laws of this Commonwealth."221 Given these circumstances, one inight wonder if a rulemaking clause was needed to prevent interference with the legislature's internal affairs. But, in fact, Virginia's framers felt compelled to reaffirm gubernatorial weakness in another, more sweeping clause: "[the governor] shall not, under any pretence, exercise any power or prerogative, by virtue of any law, statute or custom of England."2222

The specific location of the rulemaking clause within the 1776 Virginia constitution supports the view that it was meant as a check on the governor. The right of each house to "settle its own rules of proceedimg" was specified in a section that also dealt with the franchise and elections. ${ }^{223}$ These two issues were areas in which colomal legislatures sought to expand their power agamst royal restraint yet "suffered their greatest disappointments" in the decade before independence. ${ }^{224}$ For instance, two attempts by the Burgesses to require elections every seven years (with legislative sessions at least once every three years) and to expand suffrage were quashed by London's Board of Trade as infringing upon the royal prerogative. ${ }^{225}$ Similarly, a royal instruction to governors prohibited the Burgesses from creatimg any new counties or otherwise altering electoral representation after 1773.226

The section containing the rulemaking clause also guaranteed each house's right to "choose its own Speaker [and] appoimt its officers."227 This, too, had been a point of friction before the Revolution. Although the assembly's nominees for Speaker and Clerk were customarily appointed, the royal governors had insisted on their right fornally to desiguate them. ${ }^{228}$ If the rulemaking clause is construed, then, from the provisions that surrounded it in Virginia's constitution, it seems imtended to give the legislature power over matters that the Crown and the royal governors sometimes refused to grant.

220. Letter of Thomas Jefferson (July, 1816), cited in J. POLE, supra note 219, at 301.

221. VA. CoNST. of 1776, para. 7.

222. Id.

223. VA. CONST. of 1776 , para. 5.

224. See J. GreENE, supra note 208, at 358.

225. See J. POLE, supra note 219, at 142-46 (discussing Virginia Septennial Acts of 1762 and 1769).

226. See J. GREENE, supra note 208, at 383.

227. VA. CONST. of 1776, para. 5.

228. See J. GREENE, supra note 208, at 383. 
Virginia's framers, however, could have had other prerogatives in mind when they granted each house a rulemaking power-prerogatives which had never been threatened by the governors and thus needed no protection. Most colomial legislatures, for example, took for granted their right to make rules for the reading of bills, the creation of committees, the ordering of business and other similar functions. ${ }^{229}$ Furthermore, colomal legislatures had built up the same expansive claims to privilege as had the British Parhament. These privileges ranged from the traditional insistence on freedom of speech and from arrest, to the power to resolve disputed elections, to pumsh or expel members, and to hold citizens in contempt of the legislative authority. ${ }^{230}$

If Virginia's ruleinaking clause was intended to assure procedural authority in these other areas, then the argument that the clause served to separate powers in the "negative" sense-by shielding the legislature from a meddlesome executive-is inadequate. A fuller explanation emerges if one recognizes that the assembhes often invoked these rules and privileges-whether against one of their own meinbers ${ }^{231}$ or against private citizens ${ }^{232}$ - to vindicate representative government. As one student of colonial privileges has observed, the rights of asseinblies "at times strongly suggest[ed] the doctrine of the rights of nian."233 Representation "was considered one of the most important of these rights; and the need to safeguard it [by protecting privileges] seened especially pressing ...."234

This potential link between the rulemaking power and representation is crucial. Since the colonies' framers sought to strengthen the rep-

229. See M. Clarke, Parliamentary Privilege in the American Colonies 173-82 (1943).

230. Long before the Revolution, these "privileges" had come to be viewed as rights that had been granted, but the fiction of royal beneficence was maintained through the Speaker's ceremonial petition to the governor at the opening of a legislative session. Id. at 78-81. The ritual was abandoned, however, iu those New England colonies where the governor was not a royal or proprietary appointee. $I d$. at 69 . Perhaps Virgiuia's new rulemaking clause was intended to furnish a legal basis for privilege, since the petition for privileges by that state's Speaker had now lost its frame of reference, im the aftermath of revolution.

231. "[O]ne surprising element in colonial history is this willingness of the assembly to humiliate its members, together with the apparent acquiescence of the members in such humiliation." Id. at 190. Legislators could be rebuked or expelled for absence, tardiness, intemperance, or similar transgressions.

232. Legislators, for example, were often insulated from service as jurors or imprisonment for debt. Moreover, citizens who insulted or inconvenienced a member (or his servant), trespassed on a member's property, or impugned the legislature's authority were often brought before the house, interrogated and punished. Snch incidents are extensively chronicled in M. CLARKE, supra note 229, passim.

233. Id. at 82. See also, J. PoLE, supra note 219, at 514 ("The liberties of Englishmen came to be indissolubly connected with the privileges of the Commons, a lesson that was never lost on the leaders of colonial Assemblies.").

234. M. ClARKE, supra note 229 , at 130. 
resentative branch against the executive, ${ }^{235}$ one way to achieve that result was to strengthen the system of representation. A guarantee of rulemaking power could have been one element in that scheine.

To verify this possible purpose of the rulemaking clause, however, one must first understand the colonists' conception of representation. At least two views of representation mixed uneasily in the Revolutionary era. ${ }^{236}$ One of these views might be termed republican: electors were viewed as choosing representatives not to protect their parochial interests, but to join with other representatives in a collective deliberation on the common good. ${ }^{237}$ Tracing its roots to Whig doctrime of the previous century, ${ }^{238}$ this idea was waning in colomal America. Nevertheless, it retained sone vitality ${ }^{239}$ and, indeed, experienced a resurgence in the 1780 's, as many leaders recoiled from democratic "excesses" in the aftermath of revolution. ${ }^{240}$ This Whig view of representation shaped the federal Constitution, with its imdirect modes of selecting senators, presidents, and judges. Professor Garry Wills has summarized this concept of representation and Madison's exposition of it in Federalist No. 10:

The image is of "refining" in which a substance is passed through several processes-Hume's successive concoctions-to reach a pure state. For Madison, the thing to be refined is virtue. It is present in the people, who are admitted to the first concoction; otherwise their genius would not be republican. But it is in an impure state there, mingled with private interest and local bias. Through several concoctions the interest is purged....

This is the goal of representation taken siniply. ${ }^{241}$

A rulemaking clause fits particularly well within this concept of representation. If representatives collectively discover the common good by distilling virtuous policies from the people's own instimcts, they should

235. See G. WooD, supra note 218 , at 163 ("The American legislatures . . . were in fact to be the government-a revolutionary transformation of political authority ...." (emphasis added)).

236. Id. at 185 ("Despite more than a decade of intense inquiry into the nature of representation, American thinking in 1776 had still not sorted out its various aspects but stocked them all in a confused and contradictory fashion."). Professor Wood adds that "Americans blend[ed] both actual and virtual representation and thus ma[de] conspicuous what had been a basic ambiguity in their thinking about representation." Id. at 188. For further discussion of these two concepts, see infra text accompanying notes $243-48$.

237. See G. Wood, supra note 218 , at $61-64,179-80$.

238. Algernon Sidney, for example, phrased the doctrine in these memorable terms: "[I]t is not therefore for Kent or Sussex, Lewis or Maidstone but for the whole nation, that the members chosen in those places are sent to serve in Parliament." A. DE GrazIA, Public AND Republic 29 (1951) (quoting A. SIDNEY, Discourses on Government, in THE WORKS OF ALGERNON SIDNEY 496 (1772)).

239. For example, representatives of the revolutionary era were so confident of serving the public good that none of the colonial conventions (except in Massachusetts and New Hampshire) bothered to submit the new state constitutions they had drafted to ratification by the voters. J. PoLE, supra note 219, at 510.

240. See, e.g., A. DE GRAZIA, supra note 238, at 88-92; G. Wood, supra note 218, at 372-82.

241. G. Wills, Explaining America: The Federalist 226 (1981). 
have the procedural flexibility that conduces toward that discovery. As Professor Wood explains, "This kind of legislature presumed a particular sort of representation-'a house of disinterested men' who 'would employ their whole time for the public good." "242

In colomial America, however, a belief in what might be called actual or direct representation caine to dominate the republican ideal. Increasingly, colonists thought of legislators as their agents, obliged to represent their particular views. ${ }^{243}$ In the decades before Independence, this belief in actual representation was manifested im a comnitment to electoral reforms, including an expansion of many states' franchise. ${ }^{244}$ The Stamp Act crisis forced explicit rejection of the British doctrine known as "virtual representation" which held that all of the King's subjects were represented in Parliament, though only a few of them voted. ${ }^{245}$ In repudiating virtual representation, Virginia's 1776 constitution not only preserved its relatively broad franchise but also required that representatives reside in the districts that elected them, ${ }^{246}$ that electoral districts be subject to change as population shifted, ${ }^{247}$ and that elections for both houses of the legislature be held aimually. ${ }^{248}$

After the Revolution, the behef in actual representation spawned more startling developments. The public soon turned its suspicion and anger on its own newly fortified legislatures. "[T]he people were increasingly urged to take back into their own hands the power they had delegated."249 The post-Independence decade witnessed "extralegal conventions, the rehance on imstructions [to bind representatives], [and] the participation of the people in pohtics out-of-doors . . ."250 Such pohitical activities preflgured the California Progressives' efforts more than a century later.

242. G. WooD, supra note 218 , at 179.

243. See B. BAILYN, supra note 207, at 162-64; G. Wood, supra note 218 , at 181-84, 369-72.

244. See G. WooD, supra note 218, at 167-68. Even in the seventeenth century, the colonists' innovations in the electoral process they had inherited from Britain pointed toward a system of actual representation. "Residence requirements, constituency payments [of representatives" stipends], frequent elections, elections of many officers, the doctrine of instructions, the banning of place-holding by representatives, and the decline in the prestige of the real-property qualification for the vote are all manifestations of . . the 'direct democracy' idea." A. DE GRAZIA, supra note 238, at 56.

245. G. WooD, supra note 218 , at 173-76.

246. VA. CONST. of 1776 , para. 3.

247. Id.

248. Id.

- 249. G. WooD, supra note 218 , at 367 . Legislatures were assailed as a "democratic despotism," id. at 404, and "[ $t$ ]here is scarcely a newspaper, pamphlet or sermon of the 1780's that does not dwell on this breakdown of confidence between the people-at-large and their representative governments." Id. at 368. See also, Corwin, The Progress of Constitutional Theory Between the Declaration of Independence and the Meeting of the Philadelphia Convention, 30 AM. HIST. REv. 511 (1925).

250. G. WooD, supra note 218 , at 383. 
The doctrine of actual representation was not entirely incoinpatible with the republican model that it was coming to echipse. Constituents' instructions, for example, often concerned only local inatters; ${ }^{251}$ legislators were still expected to dehberate about larger concerns. Moreover, the strengthened electoral links with constituents did not foreclose legislators' working toward the common good. As Professor Wills observes, Madison thought the common good could be refined from the popular will. ${ }^{252}$

But the colomists' doctrine of actual representation does provide a sharper context for evaluating the rulemaking clause. The doctrine reinforces the view that colomial ruleinaking clauses reflected not so much a solicitude for representatives' autonomy as a desire to strengthen the people's voice through their representatives. The colonists shifted the balance of power in their new constitutions toward the legislative branch, and the rulesnaking clause probably contributed to this inproved representation.

\section{A Modern Gloss on Rulemaking}

The gloss that courts and legislators have placed on the ruleinaking clause over the past two centuries supports the conclusion that the rulemaking clause is linked to the separation of powers. While these judicial and legislative pronounceinents carry considerable weight, they must be carefully parsed. Judges and politicians have soinetimes subordinated constitutional construction to their own institutional interests.

In United States v. Ballin, ${ }^{253}$ a nineteenth century opinion upholding the House of Representatives' mode of ascertaining a quorum, the Supreme Court employed language that has since been cited as a sort of tribute to the House's inherent rulemaking capacity: ${ }^{254}$

With the courts the question is only one of power. The Constitution enpowers each house to determine its rules of proceedings. . . It is a continuous power, always subject to be exercised by the house, and within the [constitutional] limitations suggested, absolute and beyond the challenge of any other body or tribunal. ${ }^{255}$

In this excerpt, the Supreme Court seems to characterize Congress's

251. Id. at $190-91$.

252. See supra text accompanying note 241 .

253. 144 U.S. 1 (1892).

254. See, e.g., L. Deschler, supra note 22, at ch. 1, § 10: "The Supreme Court has interpreted [the Constitution's rulemaking] clause to mean that the House possesses nearly absolute power to adopt its own procedural rules" (citing United States v. Ballm, 144 U.S. 1 (1892)). See also Annot., $76 \mathrm{~L}$. Ed. 967 (1931), citing Ballin and asserting that "[t]he legislative department is thus supreme in its own field, and where its action does not violate any provision of the Federal or state Constitution, its will is practically absolute, and is not subject to review by the courts." Id.

255. 144 U.S. at 5. 
rulemaking authority as a natural right. Only the opeming and closing phrases suggest that courts' reluctance to interfere with legislatures' rules derives not so much froin the status of the rules theinselves as froin the coinplicated relationship between the judicial and legislative branches. ${ }^{256}$

In opinions like Ballin, this subtle distmction in reasoning is largely obscured. Two recent opinions by the Ninth and District of Columbia Circuits, lowever, help to clarify the distinction. ${ }^{257}$ In botli cases, the minority political party (im the Arizona and Uinted States Houses of Representatives, respectively) challenged its disproportionately small representation on certain standing committees. The leadership in each House defended the chamber's prerogative under the rulemaking clauses of the Arizona and Umited States Constitutions. In botll cases, the trial courts dismissed the complaints, suggesting that the legislators' exclusive control over their procedures precluded judicial review. ${ }^{258}$

Both appellate courts rejected these grounds for disınissal, altliough they ultimately ruled in favor of the defendants. As the District of Columbia Circuit observed,

this authorization of [rulemaking] power to Congress is not analytically different from many other constitutionally enumerated powers. So it is not evident why we must treat congressional rules with "special care" or with more than the customary deference we show other legislative enactments. ... [W]e conclude that Art. I simply means that neither we nor the Executive Branch may tell Congress what rules it must adopt. ${ }^{259}$

In ruling against the plaintiffs, the District of Columbia Circuit relied on its "discretion to withhold equitable and declaratory relief." 260 Although the court clainied it had ignored the inerits, it must have gauged the relative magnitude of plaintiffs' constitutional claims since it acknowledged that, in other cases, "the cominittee system could be mamipulated beyond reason."261 In this case, the court found that it was

256. This same critique might be applied to the California Supreme Court's opinion in French v. Senate, 146 Cal. 604, 80 P. 1031 (1905). See supra notes 7 \& 176. In French, the court framed its permissive language about the senate's organic power of expulsion with this profession of deference to a coordinate branch of government: "An attempt by this court to direct or control the legislature ... in the exercise of th[is] power, would be an attempt to exercise legislative functions, which it is expressly forbidden to do." $146 \mathrm{Cal}$. at $607,80 \mathrm{P}$. at 1032-33.

257. Vander Jagt v. O'Neill, 699 F.2d 1166 (D.C. Cir. 1983), cert. denied, 464 U.S. 823 (1983); Davids v. Akers, 549 F.2d 120 (9th Cir. 1977).

258. Pointing to the rulemaking clause in the federal Constitution, the trial court in Vander Jagt held that "[t]his textual commitment [ousts] the Court's jurisdiction." 524 F. Supp. 519, 521 (D. D.C. 1981). The reasoning of the trial court's unpublished decision in Davids was less clear, but the Ninth Circuit inferred that the lower court had found either no jurisdiction or an absence of justiciability. 549 F.2d at 126-27.

259. Vander Jagt v. O'Neill, 699 F.2d 1166, 1173 (D.C. Cir. 1983), cert. denied 464 U.S. 823 (1983) (citation and footnotes omitted).

260. Id. at 1177.

261. Id. at 1170 . 
a " 'startlingly unattractive' idea, given our respect for a coequal branch of government, for us 'to tell the Speaker of the ... House of Representatives how many Democrats . . . he is to appoimt to the standing committees." "262 Thus, the judges recognized that they had the power to intervene-that procedural rules were not sacrosanct-but that in these circuinstances they were being asked simply to substitute their judgment for the legislators'. In that situation, the court invoked the separation of powers doctrine.

The Ninth Circuit's decision against the plaintiff legislators in Arizona approached the issue of procedural autonomy im much the same way. Its formal holding, however, rested on different grounds. Noting that pohitical question and separation of powers concerns created fewer -barriers between a federal court and a state legislature, the court reached the merits of the case. ${ }^{263}$ While finding that none of the claims under the first and fourteenth amendments or 42 U.S.C. section 1983 was valid, the court also discussed in detail the difficulty of fashioning rehef, that is, of determining how committee ratios should be structured. The court appreciated the difficulty in such questions as whether ideology as well as party affiliation should count. While acknowledging that "many pohitical scientists beheve that [proportional representation on committees] is the better way for legislative bodies to conduct their business," 264 the court concluded that "[w]e are not im a position ... to make a better judgment about how the Arizona House of Representatives should go about its business than that House can make."265

When Ballin's sweeping language about the rulemaking power is read in hight of these recent circuit court decisions, a different construction einerges. The reason for judicial nonintervention in matters of legislative procedure is not that such rulemaking is an inherent right or that externally imposed rules will cripple the lawmaking process. Rather, judicial intervention usually substitutes a judge's opimon for legislators' opinions. This substitution is, as the Nimth Circuit observed, "a perversion of the judicial process into a pohtical process."266 Judicial second-

262. Id. at 1176 (quoting Davids v. Akers, 549 F.2d 120, 123 (9th Cir. 1977)).

263. Davids v. Akers, 549 F.2d 120, 126 (9th Cir. 1977). The court did claim, at one point, that "[t]he priuciple that such procedures are for the House itself to decide is as old as the British Parliament." Id. at 123. But the judges' lengthy review of the merits of the complaint and of the possibilities for relief inade it clear that they were not so much conceding complete autonomy to the house as they were explaming the absence of constitutionally protected rights. Thus, the court later declared, "It stretches the language of the First Amendment beyond recognition to make it mean that an elected nember of the state legislature ... has had his right to assemble and petition the government infringed because the Speaker of the House has not appointed him or some of his colleagues to a committee." Id. at 124.

264. Id. at 127.

265. Id. at 125 .

266. Id. at 124 . 
guessing in these cases violates the separation of powers and upsets the balance of powers, but it does not abridge any "natural rights" of legislatures.

Just as courts have sonnetimes exaggerated the duty to defer to legislatures' rules, so legislative bodies have often exalted their internal power. Nowhere has this desire to preserve the rulemaking power been carried to such an extreine as in the House of Representatives' insistence that its rules lapse at the end of each Congress. The legislators contend that one House cannot "prescribe rules for its successor."267

Neither the Constitution nor the basic tenets of parliamentary procedure require this custom. Indeed, the British House of Commons has governed its procedure for several centuries with standing orders which carry over from one parhament to another. ${ }^{268}$ For thirty years during the nineteenth century, even the United States House of Representatives abandoned the practice of renewing its rules biannually. ${ }^{269}$ Moreover, the House's rationale for renewing rules scarcely supports the practice. If the standing rules of one Congress remained in effect during the next, the new House's power to amend those rules at any time would not be diminished. In fact, the current practice produces much the same result, since the rules of one Congress are expressly adopted (often with few amendments) by its successor. ${ }^{270}$ Even when the House proceeds under "general parhiamentary law" at the outset of each Congress, this law is very largely shaped by the customs and precedents of prior

267. C. Cannon, supra note 22 , at $\S 3383$. See also L. DESCHLER, supra note 22 , at $\S 10 ; \mathrm{A}$. HiNDS, supra note 22 , at $\$ \S 187,6002,6765$.

It is not clear why this custom began. The proceedings of the second Congress indicate that a resolution was passed, on the third day, adopting the rules "of the last House of Representatives" as those "to be observed in this body, until a revision or alteration of the same shall take place." 2 ANNALS OF CONG. 143 (1791). When the fifth Congress chose its Clerk, the Speaker read one of the House rules that required nominations in any election where persons other than House members were eligible for the post. In the ensuing debate, some representatives thought that the selection of a clerk "came under the rule," while others observed that "the rules of a former House [are] not binding on a new House until that House determine[s] that they should be so." 7 ANNALS. OF CoNG. 50-51 (1797). The status of the rules was not resolved, but the House voted to proceed with nominations. Id.

268. T. Erskine May, Treatise on the Law, Privileges, Proceedings, and Usages of Pariament 185 (8th ed. 1879).

269. The rules adopted in 1860 remained in effect until 1890 under a rule that provided: "These rules shall be the rules of the House of Representatives of the present and succeeding Congresses unless otherwise ordered." A. HiNDS, supra note $22, \S 6743$. The practice might have continued indefinitely had not Speaker Reed finally insisted that the rules of the prior Congress had lapsed, thereby preparing to impose a new parliamentary regime on the House that limited dilatory tactics. Id. §6002. For a vivid account of this episode, see B. TUChMAN, ThE Proud TOWER 124-29 (1966).

270. A. HiNDs, supra note $22, \S 6742$ ("in fact the essential portions of the system of rules are continued from Congress to Congress, and become an existing code, permanent in its essential provisions" (footnotes omitted)). 
Congresses. ${ }^{271}$

While the termination of House rules at the end of each Congress is neither logical nor required, it has given the rulemaking process an elevated status. By insisting on the procedural independence of each reconstituted House, Congress has created the impression that the rulemaking power is a sovereign attribute of deliberative bodies, rather than a constitutionally delegated authority. On the federal level, this perspective is likely to endure; there are few if any circumstances under which it could be challenged. ${ }^{272}$ But the absence of a constitutional basis for this view that rulemaking is an exclusive prerogative must be borne in mind when evaluating Proposition 24.

\section{Bicameralism}

Another principle of government that fignred prominently in the colomal constitutional debates was bicameralism. Three aspects of this doctrine can be distinguished. Any one of these could have led to the drafting of a rulemaking clause. First, the clause may simply have served the convenience of each chamber; secondly, it may have augmented a separation of powers between the two chambers; or thirdly, the clause may have anticipated the chambers' different needs, corresponding to the different interests each represented.

In the first place, bicameralism was involved in the simple mechanics of government, quite apart from any theory. Because the new state and federal constitutions prescribed a mode of lawmaking that required approval of both houses with the concurrence of the governor or president, a rulemaking clause might have been necessary to permit each chamber to create rules on its own. So ntany broad purposes and values have been imputed to the rulemaking clause that this simple explanation for it inay be overlooked. It is quite possible, however, that the clause served only this practical function.

Secondly, when many colonial leaders discussed the value of bicamerahisin, they held it out as a particular application of the separation of powers doctrine. ${ }^{273}$ Thus John Adams, in his constitutional plan circu-

271. Id. $\$ \S 6761-6764$; C. CANNON, supra note $22, \S \S 3383-3386$. The fiction of discontinuity is even clearer in California. As the Legislative Counsel recently testified, "when a body fails to adopt new rules at the beginning of a new session, then under the doctrine of parliamentary law, custom and usage coines into play, and you look to the rules of the preceding session as guidelines for the operation of the body . . ." Joint Hearings, supra note 19, at 31 (statement of Bion Gregory).

272. As the decision in Vander Jagt v. O'Neill, 699 F.2d 1166 (D.C. Cir.), cert. denied 464 U.S. 823 (1983) demonstrates, legislators who challenge the Congress' internal procedures are unlikely to gain relief-even in the unlikely event that they overcome barriers of standing and justiciability. See supra text accompanying notes 257-62.

273. Indeed, Professor Wood contends that "the once distinct concepts" of separation of powers and bicameralism were "thoroughly blended" by the time of the 1787 convention, both principles serving to "[prevent] any one power from asserting itself too far." G. WooD, supra note 218, at 604. 
lated at the Virginia convention, reiterated the traditional reasons for separating the legislative, executive and judicial functions. $\mathrm{He}$ then explained that, for inost of the saine reasons, "the legislative power ought to be inore coinplex" than the unicaineral inodel. ${ }^{274}$

[I]f the legislative power is wholly in one assembly, and the executive in another, or in a single person, these two powers will oppose and encroach upon each another, until the contest shall end in war ....

To avoid these dangers, let a distinct asseinbly be constituted, as a mediator between the two extreme branches ... . 275

Madison's view was shightly different froin the one Adains held. While Madison envisioned joint action by the Senate and the executive, ${ }^{276}$ he also foresaw a rivalry of honor between the legislative chambers in which each would check the other in any unvirtuous enactments it might atteinpt. ${ }^{277}$ Professor Wills has stressed the importance of this bicameral division to the constitutional scheme. For Madison, he contends, "there is ouly one powerful check in the three powers, and that is within the legislature."278

The Supreme Court recently einbraced the view that bicameralisin reflects the separation-of-powers doctrine. The Court's interpretation of bicamerahisn is distinctive, but it remains similar to Madison's. In INS v. Chadha, ${ }^{279}$ the Court exainined whether a unicameral veto of an executive agency's action was unconstitutional. Surveymg the Philadelphia debates and the Federalist Papers, the Court concluded that the Constitution's sweeping requirement of bicameral action by the Congress derived froin the Framers' fear of "[1] egislative despotisin," a "general skepticism regarding the fallibility of huinan nature," the "need to divide and disperse power in order to protect liberty," and a consequent belief that "legislative power [should] be exercised only after opportunity for full study and debate in separate settings."280

Regardless of how one links bicameralism to the doctrine of separated powers, the imphications for the rulemaking clause seem to be the saine. The clause prevents either chamber from procedurally hamstringing the other (and thus from destroying the division). As Madison

274. 4 C. ADAMS, supra note 189 , at 196.

275. Id. Adams's praise of the bicameral form as "complex" was probably intended to repudiate Thomas Paine's claim, in Common Sense, that unicameral bodies were virtuous for their simplicity. 1 The Complete Works of Thomas Paine 6-7 (P. Foner cd. 1969). Despite the enormous popularity of Paine's essay, this point was probably not very persuasive in the face of decades of contrary practice. Most colonies had abandoned unicameral legislatures early on, although Pennsylvania adhered to the older form until 1790. See J. PoLE, supra note 219, at 280.

276. See G. Wills, supra note 241 , at $123-24$.

277. See id. at 235-36.

278. Id. at 122 (emphasis in original).

279. 462 U.S. 919 (1983).

280. Id. at $948-51$. 
explained the intent of the Philadelphia convention, the divided Congress should render both chambers "as hittle connected with each other as the nature of their common functions . . . will adnrit."281

There was a third dimension of bicameralisin. As Thomas Jefferson observed, "[t] $t$ he purpose of estabhishing different houses of legislation is to introduce the influence of different interests or different principles."282 In this respect, bicameralism awkwardly preserved the traditional Englisl belief in "mixed government." This theory that liberty required a "balance in government of the basic socio-constitutional elernents of society: king, lords, and commons"283 had dommated British pohtical thought (eclipsing the separation-of-powers doctrine) since the mid-seventeenth century. ${ }^{284}$ In a nation devoid of aristocracy, America's Framers had to rely upon otlier distinctions: the different minimum ages for senators and representatives, ${ }^{285}$ the different requirements for duration of citizenship, ${ }^{286}$ the different terms of office, ${ }^{287}$ the different inodes of election, ${ }^{288}$ the different duties assigned to each chamber, especially the origination of revenue bills in the House, ${ }^{289}$ and the difference in each chamber's size.

It is possible that the unicameral rulemaking clause served the same purpose as these other provisions, distinguishing House from Senate. By guaranteeing procedural autonomy, the Framers may have sought to ensure that each house would reniam the exclusive preserve of its respective interests. If, for example, filibusters helped to sustain the inore deliberative character of the Senate, the House would be powerless to hinit that practice. ${ }^{290}$ Had this same theory of bicameralism shaped the Califorina constitution, it night well restrain the initiative power. After all,

281. The Federalist No. 51, at 322 (J. Madison) (C. Rossiter ed. 1961).

282. T. JeFFERSON, Notes on the State of Virginia, in WRITINGS 245 (M. Peterson ed. 1984).

283. B. BAILYN, supra note 210 , at 21 .

284. W. GWYN, supra note 212, at 23-25.

It has often been said that the doctrine of the separation of powers developed out of that of the mixed constitution. ... . [But] the fact remains that the two doctrines are different in both content and origin. The separation of powers is based on an analysis of governmental functions; mixed monarchy on the "three estates," two of which are social groups, participating in the political process. ... The one can exist with unicameralism; the other, as understood in Britain, requires a bicameral legislature.

Id. at 26-27; see also G. WiLLS, supra note 241, at 97-116.

285. U.S. CONST. art. I, § 2, cl. 2 and id. § 3, cl. 3.

286. Id.

287. Id. $\S 2$, cl. 1 and id. $\S 3$, cl. 1 .

288. Id.

289. U.S. CONST. art. I, $\S 7$, cl. 1 .

290. It is interesting that Blackstone also emphasized the relationship of bicameralism to the development of separate privileges in each house of Parliament. In his gloss on Sir Edward Coke's assertion that a matter should only "be examined, discussed, and adjudged in that house to which it relates," 1 W. BLACKSTONE, supra note 199, at *158, Blackstone explained: "Hence, for instance, the lords will not suffer the commons to interfere in settling a claim of peerage; the commons will not 
if voters sought to eliminate the practice of filibusters (assuming this existed in Sacramento) through a ballot proposition, the result would undermine the aristocratic counterpoise to the popular will just as surely as if the assembly itself attempted this reform.

By the time California's constitution was fornulated in the midnineteenth century, however, the "mixed government" view of bicameralism had disappeared. ${ }^{291}$ Most of the provisions in the early state and federal constitutions that distinguished the upper and lower houses had no counterpart in California's first charter. Citizenship requireinents for members of the senate and assembly were identical. ${ }^{292}$ All legislation, including revenue bills, could originate in either chamber. ${ }^{293}$ Members of both bodies were to be elected by popular vote. ${ }^{294}$ Even the extent to which assembly and senate constituencies could differ was limited, since neither set of districts could deviate from county boundaries. ${ }^{295}$

An amendment at the 1849 convention to impose different minimum ages for members of the assembly and senate produced an illuminating debate. One delegate asked: "Could any gentleman explain what there is in the Senate to make a member an immature man who was a mature man in the House below?"296 Another questioned the convention's right "to put restrictions on the people" and argued: "Let them send whom they please either to the House or the Senate. They are best qualified to judge as to the capability of members." ${ }^{\text {297 }}$ The clause stipulating age limits was defeated. ${ }^{298}$

Whatever purpose California's framers had in mind in creating a bicameral legislature, it did not include interposing a less "popular" upper house between the voice of the people and the enactment of public

allow the lords to judge the election of a burgess; nor will either house permit the courts of law to examine the merits of either case." Id. at $* 159$.

For discussion of how the post-Revolutionary American states tried to distinguish their legislative chambers by giving the upper houses more "stability and permanence," see J. POLE, supra note 219, at 292 .

291. Indeed, it was already waning in the colonial period. See G. WoOD, supra note 218, at 560. As Charles Pinckney observed at the Philadelphia convention, "[a]mong [Americans] there are fewer distinctions of fortune and less of rank, than among the inhabitants of any other nation." 1787 DEBATES, supra note 193, at 181.

292. CAL. CONST. of 1849 , art. IV, $\S 5$.

293. Id. $\S 16$.

294. Id. $\S \S 3,5$.

295. Id. $\$ 30$.

296. 1849 DEBATES, supra note 112 , at 83 .

297. Id. at 84 .

298. Aside from size, the only remaining difference between assembly and senate was the term of office: two years in the former, four in the latter. Evidently, this distinction was not very important, since the 1879 convention seriously considered amending the constitution to provide quadrennial elections for all offices. See 21879 DEBATES, supra note 112, at 742-44. 
laws. To the extent that an aristocratic principle underlying the senate might preclude voters' enactment of senate rules, the argument has no force in California.

\section{Other Purposes}

Professor Wills has einphasized that the debate over the nature of constitutional government during the Revolutionary period was "almost equally creative and confusing. Men had borrowed their enemies' arguments, added new ones, conflated old ones. They creatively misunderstood or mistakenly expounded each other. Much of the modern scholarship in this area has been a labor of disentanglement."299 Partly for this reason, it is difficult to uncover the real purpose of the rulemaking clause. The preceding Sections suggest that the clause reflected certain aspects of bicamerahsin and the separation of powers. These suggestions accord fairly well with the conditions of the period, but they do not preclude the clause from serving other functions. As Wills points out, theories overlapped; they were seldom mutually exclusive. ${ }^{300}$

Is there any evidence, then, that the framers conceived of the rulemaking clause as a guarantee of procedural autonomy for the legislature-as a prerogative upon which voters camiot infringe? Such a reading of the rulemaking clause caunot be derived simply from the clause's wording. It is true, of course, that by its terins the clause grants procedural authority to the legislators and to no one else. But this may serve only to prevent the judiciary and the executive from interfering with legislative procedures. It does not answer the question of whether voters are also excluded from the procedural domain. The idea of direct democracy, after all, was unthinkable to California's framers (or to their colonial predecessors who drafted earher constitutions).

The wording of the rulemaking clause is thus inconclusive; one must search elsewhere for evidence that the clause prevents voters from enacting rules. Those who contend that the ruleinaking clause guarantees procedural autonomy must therefore believe that the early framers had a theory underlying the rulemaking clause and that this theory insulates parhamentary rules froin the voters' reach, now that the voters can exercise the initiative power. The only theory that really fulfills this purpose is one that views procedural autonomy as indispensible to the lawmaking process. This theory holds that legislative bodies cannot properly produce laws unless they can structure every aspect of their own proceedings.

It is difficult to test whether the constitutional framers held this

299. G. WILLS, supra note 241 , at 97.

300. Id. 
view. There are reasons, however, for doubting that political leaders of the eighteenth and nineteenth century regarded procedural autonoiny (as distinct from a rulemaking capacity) as an essential attribute of legislative bodies.

For the nineteenth century view, one turns to Luther Stearns Cushing, whose treatises on parhamentary law dominated the era when California's first constitution was written. Cushing accorded great respect to the procedural traditions that legislatures liad developed. ${ }^{301}$ But whether he beheved that procedural constraints could not be imposed externally is far less clear. For exainple, Cusling stated that

it is more material, perhaps, that there should be rules established, thian that they should be founded upon the firmest basis of reason and argument; the great object being to effect a uniformity of proceeding in the busimess of the assembly, securing it at once against the caprice of the presiding officer, and the captious disputes of members. ${ }^{302}$

In this passage, Cushing echoed eighteenth century predecessors like Hatsell and especially Jefferson, wlio was even more blunt on the same point: "It is much more material that there sliould be a rule to go by than what that rule is."

Jefferson rejected procedural autonomy more explicitly in his Notes on the State of Virginia. In that work he listed as one of six major flaws in Virginia's constitution that the assembly could determine the size of its own quorum. ${ }^{304}$ Durimg the Revolutionary War, the assembly had voted to reduce its quorum to less than a majority, and Jefferson foresaw a threat of monarchy or oligarchy. Far from deferring to an abstract claim of prerogative, Jefferson noted derisively that the assembly claimed the right to make this change only because "the British parliainent fixes its own quorun: our forner assemblies fixed their own quorum: and one precedent $\mathrm{m}$ favour of power is stronger than an luundred against it."

The colomists appeared no more respectful of another time-honored prerogative of legislatures: the riglit to control memberslip. Popular antagomsm on this issue was sharpened by the infamous Wilkes case. The British Parhament expelled John Wilkes for seditious libel in 1769 and then persisted in excluding him when he was successively reelected. In Powell v. McCormack, ${ }^{306}$ the United States Supreme Court observed that "[Wilkes'] riglit to be seated in Parhiament became a cause celebre for the colonists. '[T] he cry of "Wilkes and Liberty" echoed loudly across the Atlantic .... Colonials tended to identify their cause witl

301. L. Cushing, supra note 113, at 306-11.

302. Id. at 305 (footnote citing J. HATSELL, supra note 203, omitted).

303. T. JEFFERSON, supra note 204, at 14.

304. T. JEFFERSON, supra note 282, at 251.

305. Id.

306. 395 U.S. 486 (1969). 
that of Wilkes." "307 Accordingly, the Powell Court found that the Constitution's Framers intended to prohibit Congress from controlling its membership through exclusion. ${ }^{308}$

Of course, this kind of evidence cannot disprove the California Legislature's contention, in the Proposition 24 case, that the rulemaking clause guaranteed procedural autonomy as an indispensable part of the legislative process. What can be said, however, is that the legislature's view of the clause's origins is less plausible than other explanations. Moreover, neither the legislature nor the courts-who apparently accepted the legislature's view-have furnished any evidence to support their particular construction of the rulemaking clause. Given the historical context of the early constitutions, it seems more likely that the rulemaking clause served such goals as the separation of powers, effective representation, and bicameralism.

\section{$\mathrm{V}$}

\section{The Constitutional IsSUES ReCONSIDERED}

This study began with the observation that Proposition 24 seemed to place article II, section 8 and article IV, section 7 of the California constitution in direct conflict. The subsequent Sections examined the purposes and histories of the two clauses. In light of that discussion, this final Part now reassesses the putative conflict between the initiative and rulemaking provisions.

Analysis of the first clause has shown that the initiative power operates under very few constitutional constraints and has traditionally been broadly construed. ${ }^{309}$ The sole limitation which inight interfere with Proposition 24 is the requirement that initiatives embody statutes. Proposition 24 meets that test fornually (by adding sections to the state Government Code similar to those the legislature itself has enacted), and apparently this is all that the California Supreme Court requires. ${ }^{310}$ Proposition 24 may not meet more restrictive criteria for identifying statutes, such as the functional test set forth by the court of appeal im People's Advocate, Inc. v. Superior Court. ${ }^{31}$ But those criteria are problematic as they tend to prove too much. If strictly employed, they preclude voters' enactment of any political refornis which touch on legis-

307. Id. at 530-31 (citation onitted). The Court noted that the Pennsylvania Council of Censors, expressly repudiating Parliament's treatnent of Wilkes, denounced the state assembly in 1786 for having iniproperly expelled a meniber. Id. at 529-30.

308. Id. at 547.

309. See supra text accompanying notes 66-96.

310. See supra text accompanying notes 100-10.

311. $181 \mathrm{Cal}$. App. 3d 316, 226 Cal. Rptr. 640 (1986). See supra text accompanying notes 141 45. 
lators' "internal" behavior. ${ }^{312}$ Moreover, the court's functional test distinguishes procedural statutes from other laws on the ground that the former are actually rules, since they nust be subject to unicameral amendinent. It is doubtful that this reflects the law or practice in Califorma. ${ }^{313}$ Even if this were the law, a court could modify Proposition 24 to meet this purported requirement of unicaineral amendability. ${ }^{314}$ In sum, the constitution's direct limitation on initiatives, the requirement that they embody "statutes," does not appear to prohibit Proposition 24.

Examination of the ruleniaking clause in the California constitution has shown that there is no constitutional history, either at the state or the federal level, that reveals its origius. ${ }^{315}$ The reasoning and purpose that generated the clause are thus open to speculation. If the underlying principle is bicameralism, the rulemaking clause would serve to maintain either a diffusion of power, by preventing one chaniber from controlling the other, or a separation of socio-economic interests in the two bodies. ${ }^{316}$ The former purpose has no bearing on the voters' capacity to impose rules on either chamber, unless such rules give one chamber some measure of procedural control over the other, which would defeat the intended separation. Proposition 24, however, contains no such provisions; its procedural "reforms" are separately addressed to each branch of the legislature. Bicaneralism's other purpose, the separation of socioeconomic interests, is not relevant to California's constitution. ${ }^{317}$

If, on the other hand, the primciple underlying the rulenraking clause is the separation of powers doctrine, then that clause's implications for Proposition 24 are more difficult to assess. Interpreting the rulemaking clause as a means of separating powers could yield two conclusions. The clause might signify only that the otler two branches are prohibited from any interference with the legislature's internal procedure. That is, article IV, section 7 might operate negatively, holding the judiciary and governor in check. ${ }^{318}$ Viewed in this light, the rulemaking clause would not seem to limit the voters' ability to inipose procedural requirenients on the legislature. For, if Proposition 24 is given effect, the rulenraking clause will continue to prevent the governor or judiciary from interfering with legislative procedure. Under this view, Proposition 24 does not conflict with separation-of-powers doctrine.

But the rulemaking clause could also be interpreted under an affirmative view of separated powers-that is, as part of a shift in the balance of

312. See supra text accompanying notes $155-57$.

313. See supra text accompanying notes 111-30.

314. See supra text accompanying notes 131-39.

315. See supra text accompanying notes 178-97.

316. See supra text accompanying notes 273-90.

317. See supra text accompanying notes 291-98.

318. See supra text accompanying notes 217-28. 
powers toward the representative branch. ${ }^{319}$ The colonial framers and California's founders niay have ensured ruleniaking autononiy because they beheved a legislature could thereby assert itself nost effectively, not only against encroachments fron the executive but, inore generally, in its representation of the people's will and the common good. Drawnig on the parhainentary tradition of procedural privileges, these constitutional drafters niay have regarded rulenıaking flexibility as part of a strong and effective systen 1 of representation.

Among the possible interpretations of the ruleniaking clause, ouly this last one sustains the prospect of a constitutional conflict in the wake of Proposition 24. On an abstract level, the conflict seenis irreconcilable: the voters' right to legislate reforns is pitted against the legislature's choice of whatever internal structure naximizes its weight and influence in the systen of government. In practice, however, the conflict appears less autonratic.

A procedural requirement imposed by the voters will not always be the sort that weakens the legislature's pohtical stature. In addition, sonie refornis niay weaken the legislature's influence in sniall ways and yet clearly enibody the type of check on abuses that the imitiative power was ineant to allow. For example, if a voter initiative required open nieetings for a state legislature's committees, the legislature umght challenge the measure on the grounds that open neetings weaken its standing and effectiveness, relative to the other branches of governnient. To some extent, this claim would be valid. It seenis doubtful, however, that a court would give equal weight to the voters' and the legislature's clainis in these circuinstances. In this era, at least, a legislature's prerogative to shroud its debiberations in secrecy siniply would not outweigh the pubhic's claim to open government. ${ }^{320}$

In practice, then, resolving particular conflicts between the legislature's ruleniaking authority and the people's power to reform the governnient requires a judgment about the relative weight to be given each constitutional clause. One general priniciple of constitutional construction in California affects that analysis. Broadly phrased, this principle holds that the California constitution is a restramt upon the legislature. This principle, which the next Section of this Comment explores in sonie detail, ${ }^{321}$ reflects the modern shift toward a theory of direct or actual representation. In the conflict between the rulemaking clause and the

319. See supra text accompanying notes 229-52.

320. Cf. Buckley v. Valeo, 424 U.S. 1, 67 (1976) (political contribution disclosure requirements, which "deter actual corruption and avoid the appearance of corruption," serve a sufficiently compelling government interest to overcome possible infringement of first amendment rights).

321. See infra text accompanying notes 328-49. 
initiative power, the principle that the constitution restrains the legislature should tip the balance in favor of the voters' authority.

To see why the balance tips toward the voters, recall the importance of Whig principles in America's early years. As noted before, if the original rulemaking clauses reflected a pohitical shift in favor of legislatures, then the purpose of those clauses was probably influenced by a republican conception of representation. ${ }^{322}$ Electors chose representatives who were trusted to deliberate on the common good, and procedural flexibility maximized that deliberative process. Today, however, this concept of representation has largely given way to one of actual representation. Representatives are now chiefly expected to serve their constituents.

The Supreme Court's decisions in legislative apportionment cases over the last twenty-five years reveal the triunph of direct representation in America. Having held that "all who participate in [an] election are to have an equal vote" 323 the Court has further declared that "representative government is in essence self-government . . . and each and every citizen has an inahenable right to full and effective participation in the pohitical processes of his State's legislative bodies." 324 As Professor Stuart Brown observes, "[o]bviously, the principle 'one voter, one vote' imphes [a] view of deinocracy, in which representatives are to be conceived as delegates rather than trustees . . . [and in which] people as individuals rather than communities . . . are to be represented." 325 Indeed, in the niost recent reapportionment decision, the Supreme Court plurality limited redress of pohtical gerrymandering to extreme cases because

the power to influence the political process is not limited to winning elections. An individual or a group of individuals who votes for a losing candidate is usually deemed to be adequately represented by the winning candidate and to have as much opportunity to influence that candidate as

322. See supra text accompanymg notes $237-42$.

323. Gray v. Sanders, 372 U.S. 368, 379 (1963). Cf. United Jewish Organizations v. Carey, 430 U.S. 144 (1977) (white Hasidic Jews who had dominated a single senate and assembly district could be redistributed among several districts to satisfy the nondiscrimination goals of the Voting Rights Act).

324. Reynolds v. Sims, 377 U.S. 533, 565 (1964); see Rogowski, Representation in Political Theory and in Law, 91 ETHICs 395, 429 (1981) (observing that the doctrine developed in Gray and Reynolds "logically requires what the Court has not even intimated that it is ready to provide: [proportional representation] or at-large election of every representative body at every level."). But cf. Davis v. Bandemer, 54 U.S.L.W. 4898, 4904 (U.S. June 30, 1986) (plurality opinion) ("Our cases ... clearly foreclose any claim that the Constitution requires proportional representation .....").

325. Brown, Black on Representation: A Question, 10 Nomos: REPRESENTATION 148 (1968). But see Black, Representation in Law and Equity, 10 Nomos: REPRESENTATION 131 (1968). Professor Black concludes that the Supreme Court's apportionment decisions do not resolve the question of whether representatives are trustees or delegates. Id. at 142. But he also suggests, as the underlying rationale for the Conrt's decisions, "that it has been the vote, and the influence of the vote, that our political society has regarded as the chief of all protections against wrongful or undesired exercise of goverumental power." Id. at 137 (emphasis in original). 
other voters in the district. ${ }^{326}$

The modern behef in actual representation, which the Supreme Court's rulings exemplify, inust be kept in perspective. Legislatures are still deliberative bodies, and the rulemaking clause enhances that function. But the doctrine of direct representation does impose certain limits on the older concept of the wise few governing for the many. Indeed, the "main aim of hiberal reformers in the past two centuries has been ... to extend popular control over the actions of legislators and administrators." 327 This impulse to control representatives has been especially strong in Califorma.

\section{A. The Shift Toward a Theory of Actual Representation in California's Government}

As the Califorma Supreme Court has observed, "[u]nlike the federal Constitution, which is a grant of power to Congress, the Califorina Constitution is a limitation or restriction on the powers of the Legislature." 328 In this statement, the court echoed the consistent view of its predecessors over the past one hundred twenty-five years. Indeed, this fundamental principle shaped the California constitution not only at the inoinent of its birth, in 1849, but on the subsequent occasions of its substantial revision: the redrafting in 1879 and the addition of the initiative and referendum power in 1911. A brief review of those formative moments will make this principle clear. ${ }^{329}$

At an early point in the 1849 convention, delegates debated whether to add the following section to their Bill of Rights: "This enumeration of rights shall not be construed to inpair or deny others retained by the

326. Davis v. Bandemer, 54 U.S.L.W. 4898, 4904 (U.S. June 30, 1986) (plurality opinion) (emphasis added).

327. A. BIRCH, REPRESENTATION 109 (1971).

328. Methodist Hosp. v. Saylor, 5 Cal. 3d 685, 691, 488 P.2d 161, 164, 97 Cal. Rptr. 1, 4 (1971).

329. The circumstances which prodnced the initiative amendment to the state constitution are of legal, and not merely historical, significance. As the California Snpreme Court has explained, historical evidence directly shapes judicial construction. Constitutional provisions "must be interpreted as nearly as possible im consonance with the objects and purposes in contemplation at the time of their adoption," Story v. Richardson, 186 Cal. 162, 165, 198 P. 1057, 1058-59 (1921), and "in such manner as to give effect to the intent of the voters adopting it." Kaiser v. Hopkins, 6 Cal. 2d 537, 538, 58 P.2d 1278, 1279 (1936). Moreover, "evidence of [an amendment's] purpose may be drawn from many sonrces, including the historical context of the amendment, and the ballot arguments favoring the measure." California Housing Finance Agency v. Patitucci, $22 \mathrm{Cal}$. 3d 171, 177, 583 P.2d 729, 733, 148 Cal. Rptr. 875, 879 (1981).

It is also important to recognize that the different principles underlying the Califoruia and federal constitutions (that is, restrained powers rather than delegated ones) should not affect the carlier conclusion that the rulemaking clauses in the state and federal charters reflect the same political theory. See supra text accompanying note 187 . The principle of restrained power affects the scope of a legislature's authority as against the residual power of the voters. But it should not alter the political principles that spawned particular constitntional provisions (such as the theory of bicameralism, separation of powers, etc.). 
people." 330 This summary clause had been borrowed from Iowa's constitution. ${ }^{331}$ During the debate, an alternative (and apparently original) clause was proposed. This clause asserted that the entire constitution "ought to be construed strictly, and all powers, not expressly granted, should be taken to be reserved." 332

It was the discussion of this alternative clause which first revealed the constitution to be a document of restraint. "[T] here is a marked difference between the Federal Constitution, and that of a State," ${ }^{333}$ one delegate declared. "The Constitution of the United States, is a delegation of power from a confederation of sovereign and independent states . . . [but] [i]t is impossible to direct your State Legislature what it shall do. You can only say what it shall not do . . ."334 Another delegate concurred: "The State Legislature, under the specified restrictions imposed upon it by the people themselves, is a direct emanation from the people ...."335 In the end, the alternative clause was defeated, and Iowa's language was approved.

In large measure, the principle of restriction simply reflected the different conceptions of state and national governments in a federal system. But this debate contained the seeds of something else as well. What delegates meant when they spoke of the constitution's "restrictions" was left unclear. At one inoment, delegates seemed to think the people restricted themselves through the constitution; at other times, the debate implied that the people restrained their agents by reserving the power to themselves. ${ }^{336}$ This anbiguity was resolved in favor of the latter view by the time another constitutional convention met im Sacramento in 1879.

California's second constitution, which has governed the state to this day, was forged in an atmosphere of discord, apprehension about conditions im the state, and great hostility toward legislators who were thought to have ignored serious problems while catering to special interests. As Professor Carl Brent Swisher observed, the Sacramento delegates were not only

determined to cinch capital, tax mortgages, and expel the Chinese, they were also determined to put the legislature in its place. Session after session charges of incoinpetence and corruptiou had been made .... The

\footnotetext{
330. 1849 DEBATES, supra note 112 , at 50.

331. Id. at 51.

332. Id.

333. Id.

334. Id.

335. Id. at 52-53.

336. In this respect, the second clause that delegates inserted into the Declaration of Rights is significant: "All political power is inherent in the people. Government is instituted for the protection, security and benefit of the people; and they have the right to alter or reform the same, whenever the public good may require it." CAL. CoNST. of 1849, art. I, $\S 2$. This clause reinforces the notion that a constitution is an instrument of restrained agency.
} 
convention set out to chastise the legislature by limiting its sphere of action .... 337

The chief result was the inclusion of article IV, section 25 in the 1879 constitution. This lengthy clause prohibited the legislature from passing "special" rather than "general" laws and histed thirty-two categories of special statutes that were especially proscribed. ${ }^{338}$

The 1879 convention also considered proposals to reduce the legislature's size and to limit it to quadrennial meetmgs. Article IV, section 25 provided the main justification for these proposals since, as one delegate noted, more than 500 of the 700 laws enacted by the legislature prior to 1878 fell within the new ban on special statutes. ${ }^{339}$ Expanded representation would not be "as necessary now in this Constitution as it was in the old Constitution," said one delegate, simce "[w]e propose to take this class of legislation away froin the Legislature and vest it directly in the people of the several counties." ${ }^{340}$ The delegates also added a clause to the Declaration of Rights asserting that all provisions of the constitution were "mandatory and prohibitory" unless otherwise noted. ${ }^{341}$

These efforts to circumscribe the legislature's capacity for mischief only partly succeeded. On the one hand, courts enforced the ban on special laws fairly strictly, mvahdating numerous statutes. ${ }^{342}$ Yet, in the thirty years following adoption of the 1879 constitution, not one bill opposed by the Southern Pacific Railroad was enacted in Sacrainento. ${ }^{343}$ Meanwhile, public tolerance for legislative malfeasance dimimished sharply with the influx of midwestern Protestant farmers who helped sweep Hiram Johnson and the Progressives into office in 1910.344

Not only the public campaign for the mitiative annendment, which

337. C. Swisher, Motivation and Political Technique in the California Constirutional CONVENTION of 1878-79, at 96 (1969).

338. Areas in which "special" laws were expressly prohibited by art. IV, $\S 25$ included: "punishment of crimes and misdemeanors" (cl. 2); "[g]ranting divorces" (cl. 5); "[r]egulating county and township business" (cl. 9); "assessment or collection of taxes" (cl. 10); "[r]eleasing or extinguishing in whole or in part, the indebtedness, hability, or obligation of any corporation or person to this State" (cl. 16); "[g]ranting to any corporation, association, or individual any special or exclusive right, privilege, or immunity" (cl. 19); and so on. This section was revised and renumbered in 1966. The new version is CAL. CoNST. art. IV, $\S 16$.

339. 1879 DEBATES, supra note 112, at 757-58. Another delegate, after reading the text of the new art. IV, $\S 25$ to his colleagues, concurred: "Now, it will be seen from this what a load of special legislation will be removed." Id. at 750.

340. Id. at 752 .

341. CAL. CoNST. art. I, § 22 (renumbered 1970) (currently CAL. CoNST. art. I, § 26).

342. See, e.g., Ex parte Sohncke, 148 Cal. 262, 82 P. 956 (1905) (usury limit imposed only on certain lenders was a special law); People v. Central Pac. R.R., 83 Cal. 393, 23 P. 303 (1890) (act specifying certain form of pleading in suits for collection of railroad taxes was a special law); $E x$ parte Westerfield, $55 \mathrm{Cal}$. 550 (1880) (a "Sunday law" prohibiting enumerated forms of labor on the Sabbath was an unconstitutional speeial law).

343. McFarland, Protestant Reformers Who Thought Politics Was Sin, 15 CAL. J. 388 (1984).

344. Id. at 388-89. 
Governor Johnson championed, but the ballot arguments themselves trumpeted the intention to curb legislative power. "The people" were declared to be

the creators of legislatures. They are the employers, and they must be clothed with the power to issue commands, to exact obedience and to negative and nullify the acts of their agents and servants, if they violate the wish or the will of their employers or the spirit of their employment. ${ }^{345}$

The ballot arguments further noted that initiatives, once passed, could never be amended or repealed "except by the people" and that the constitutional amendinent to create initiatives was commended as inuch by "the character of those who oppose it" as by its own merits. ${ }^{346}$ Proponents of the new systein closed their statement on this note:

The voters are to decide by the adoption, or rejection, of this amendment to the constitution, as to whether self-government is a success or failure; as to whether the people believe in themselves. It is the step which brings legislation to the threshold of the individual and clothes him with the power to secure good laws by control over legislators and legislatures. ${ }^{347}$

The California Supreme Court, in expounding the initiative clause, has frequently affirmed this account of its origins. "By the enactment of initiative and referendum laws," the court has said, "the people have simply withdrawn froin the legislative body and reserved to themselves the right to exercise a part of their inherent legislative power." ${ }^{348}$ Elsewhere, the court has stated that the inclusion of initiative and referendum powers within the constitution "iniplies ... a conclusion on the part of very inany people, that the representative body known as the legislature cannot always be rehed on to express the real desire of the people of a state." 349

\section{B. Reassessing the Conflict Between the Initiative and Rulemaking Clauses}

The principle of restricted power in California's constitution auginents the voters' claim of authority, under the initiative clause, when that authority conflicts with the legislature's rulemaking power. The reason is that the constitutional principle of restraining the legislature reflects a different view of representation than the one that underlies the rulemaking clause. If the rulemaking clause originates in the separation-

345. Gates \& Clark, supra note 62.

346. Id.

347. Id.

348. Dwyer v. City Council, 200 Cal. 505, 513, 253 P. 932, 935 (1927).

349. Barlotti v. Lyons, 182 Cal. 575, 583, 189 P. 282, 285 (1920); see also Associated Home Builders, Inc. v. City of Livermore, 18 Cal. 3d 582, 591, 557 P.2d 473, 477, 135 Cal. Rptr. 41, 45 (1976). 
of-powers doctrine (and this is the only interpretation of the clause that could limit voter initiatives), then it reflects an older, republican view of representation. The clause's purpose is to strengthen the representative branch of government by enhancing its deliberative process. But Califorinans have fortified their systein of representation much more directly. They have chosen to restrain legislators who do not faithfully represent them by reserving the initiative power. Assessing Proposition 24 's constitutionality, then, requires balancing a specnlative imterpretation of the rulemaking clause (namely, that it enhances a republican conception of representation) against the clear purpose of the initiative clause, whicli is to curb legislative power.

In these circumstances, one may wonder whether the rulemaking clause could ever restrict the voters' enactment of "reforms" through initiatives. The probable answer is that the rulemaking clause could still preclude certain reforms. There are procedural requireinents that, if imposed by initiative on the legislature, would so weaken the legislature's political role as to threaten the balance of powers or the functioning of representative denocracy. Yet, if a reform initiative truly posed that threat, courts should not have to rely on a speculative interpretation of the rulemaking clause to invalidate the initiative. If the danger posed were the destruction of the balance of powers, this should be unconstitutional in its own riglit, quite apart from the rulemaking clause. ${ }^{350}$

In addition, while reforms that jeopardize the balance of powers are conceivable, it is hard to understand wliy the people would enact them. Voters have a strong interest in preserving a legislative brancls that represents them effectively. By contrast, the legislature's majority may have a strong interest in enacting rules that concentrate power in the leadership at the expense of the reinaining members. As Hatsell, Jefferson, and Cushing pointed out, it was this very danger of inajority tyranny that defined a crucial function of procedural rules. In Jefferson's words, it was inıportant to have "a uniformity of proceeding in business not subject to the caprice of the Speaker"351 and rules "by which the minority can defend themselves against ... throse in power ....9352 On the whole, then, legislators inay have a greater incentive than voters to distort the systein of representation by altering procedural rules.

There is one factor, however, that undermines this conclusion. Legislators, because of their familiarity with the workings of tle representa-

350. See, e.g., Bixby v. Pierno, 4 Cal. 3d 130, 141, 481 P.2d 242, 249, 93 Cal. Rptr. 234, 241 (1971) ("The separation of powers doctrine articulates a basic philosophy of our constitutional system of government; it establishes a system of checks and balances to protect any one branch against the overreaching of any other branch." (citations omitted)).

351. T. JeFFERSON, supra note 204, at 14.

352. Id. 
tive branch, are more likely to appreciate the risks that some procedural clianges create. Voters may blithely disregard those risks. This fact might cause courts to evaluate the constitutionality of rules enacted by mitiative more harshly. For example, if the public believed that popular legislation was being bottled up in committees by hostile chairpersons, voters might enact new rules requiring that all bills introduced in the legislature receive consideration and a vote by the full membership of the senate and assembly. Given the number of bills introduced, this could create havoc in the legislature and severely erode its effectiveness. ${ }^{353}$ Yet, if the legislature enacted the same "reform," a court would no doubt presume that the legislature had evaluated the dangers and had in mind some method of mitigating them.

Thus, when a court faces a conflict between a "reform" initiative and the legislature's rulemaking power, and if the court construes the rulemaking clause as serving to strengthen the representative branch in the balance of powers, then the court should assess whether the initiative imposes untenable restramts on the legislature. ${ }^{354}$ Courts will not wel-

353. For a discussion of how Congress (and, by analogy, legislatures) regulate their committees' and full chambers' consideration of bills to produce stable majorities, see A. MAASS, CoNGRESS AND THE COMMON GoOD 77-116 (1983); Bruff, Legislative Formality, Administrative Rationality, 63 TEX. L. REV. 207, 213-26 (1984).

354. Courts might not turu to the principle of restricted power to reconcile the initiative and rulemaking clauses. In the past, the restriction principle has been used to uphold actions by the legislature against allegations of unconstitutionality. For example, in Methodist Hosp. v. Saylor, 5 Cal. 3d 685, 691, 488 P.2d 161, 165, 97 Cal. Rptr. 1, 5 (1971), the court said that because the constitution was framed as a restraint on the legislature, that body "may exercise any and all legislative powers which are not expressly or by necessary implication denied it by the constitution." The principle of restriction was thus transformed into a principle of deference. Nevertheless, that deference was prompted by allegations that the legislature had acted beyond its authority. Id. The situation is very different when the legislative and initiative powers directly conflict. In that context, the principle of restricted power should favor the voters' power over the legislators'. The state supreme court may not agree, however, judging by some of its dicta in Legislature of Cal. v. Deukmejian, 34 Cal. 3d 658, 669 P.2d 17, 194 Cal. Rptr. 781 (1983).

In Deukmejian, the court touched upon a potential conflict between voters and legislators that is uniquely analogous to the one that Proposition 24 now raises. That potential conflict involved the power to promulgate reapportionment plans. The court, as noted earlier, supra note 89 , invalidated a redistricting initiative because the legislature had already enacted a plan; the justices held that two such plans in one decade would be unconstitutional. But the Deukmejian majority reached that decision after first "[a]ssuming, but not deciding, that redistricting by initiative is permissible." Id. at 673,669 P.2d at 26, $194 \mathrm{Cal}$. Rptr. at 790. The source of the justices' doubt on this point was art. $\mathrm{XXI}$ of the state constitution which sets forth the procedure for decennial reapportionments and which directs that "the Legislature shall adjust the boundary lines." CAL. CoNST. art XXI, $\S 1$.

The parallel between this provision and the wording of the rulemaking elause is notable. Both clauses assign a task to the legislature that can be (and that is, in the case of reapportionment) achieved through ordinary statutes. In turn, statutes comprise the very category of enactments purportedly available to the voters through the initiative power. Yet, by declining to state that redistricting by initiative was possible, the Deukmejian court implied that when the constitution discusses a statutory task to be accomplished "by the legislature," this excludes the voters from that legislative domain. The justices seemed disinclined to think that, because the initiative power restricts the legislature's power, initiatives should have the stronger claim in a direct conflict with the 
come the difficult task of drawing such lines. But that task is not analytically different from the challenge that faced the District of Columbia Circuit three years ago, when Speaker O'Neill stocked House committees with "too many" Democrats. The court, as already noted, declined to sustain the Repubhicans' complaint in that instance, but it expressly recognized "that the committee system could be mainpulated beyond reason," in which case a court might have to intervene. ${ }^{355}$ The court einphasized that "this is not an area fit for inflexible doctrines or brightline tests."356 As an example of unavoidable line-drawing, the court noted that the speech and debate clause, which ostensibly offers complete immunity to legislators in their official acts, had been circumscribed by the Supreme Court when Congress's immunity was "strained by egregious circumstances."357

\section{Proposition 24's Constitutionality}

In the present controversy, then, a court must evaluate the extent to which Proposition 24's various provisions undermine the legislature's stature and effectiveness within California's government. For these purposes, the mitiative's "reforns" can be usefully placed in four categories: (1) provisions that have shight, if any, effects on the legislature; (2) provisions that affect the legislative process but that the California Legislature has itself adopted at one time or another; (3) provisions that the California Legislature has never adopted but that other state legislatures have; and, (4) provisions that would impose umque restraints on the California Legislature.

legislature. (If any conflict between voters and the legislature invited the court to use the "restriction of power" principle in construing the initiative clause, it was surely the recent dispute over reapportionment. The redistricting initiative, which the Deukmejian court rejected, followed the voters' defeat (by referendum) of the legislature's first reapportionment plan in 1982. That plan had been widely criticized as excessively partisan, and the voters' swift response called to mind the 1911 ballot arguments that had promised "the people the power to arrest, and prevent the taking effeet, of vicious or objectionable acts of the legislature." Gates \& Clark, supra note 62.)

Of course, there are other, inore general principles of constitutional construction that the courts might draw upon in reconciling art. II, $\S 8$ and art. IV, $\S 7$. Some of these could favor the legislature's power under the latter clause. For example, a "specific provision relating to a particular subject will goveru a general provision, even though the general provision standing alone would be broad enough to include the subject to which the specific provision relates." People v. Tanner, 24 Cal. 3d 514, 521, 596 P.2d 328, 331, 156 Cal. Rptr. 450, 453 (1979). Since the rulemaking clause pertains to only a small portion of legislative enactments, it seems more specific than the initiative clause.

355. Vander Jagt v. O'Neill, 699 F.2d 1166, 1170 (D.C. Cir.), cert. denied 464 U.S. 823 (1983). See supra text accompanying notes 259-62.

356. Id. at 1175 .

357. Id. (citing United States v. Brewster, 408 U.S. 501 (1972) (prosecution for bribery not foreclosed by Senator's protection under the specch and debate clause); Hutchinson v. Proxmire, 443 U.S. 111 (1979) (Senator's press release not immunized against libel suit by speech and debate clause)). 
First, there are provisions that do not seem to alter the legislature's effectiveness in any material way. These imclude, for example, the accountability sections, which require public reports on, and independent audits of, the legislature's own spending ${ }^{358}$ and which prohibit sloppy voting practices in either chamber. ${ }^{359}$ While the legislature may benefit from obfuscation in some indeterminate way, the right to protect such practices hardly rises to the level of constitutional justification.

The second category encompasses those sections that, while they may alter the legislature's effectiveness in some way, are similar to practices that the California Legislature has itself followed at some time. Such prior experience would suggest that these provisions pose little danger. This category includes the requirement of a two-thirds vote to suspend the rules, ${ }^{360}$ a procedure that at least the Assembly imposed on itself until 1982,361 and the provisions requiring open meetings and limiting executive sessions, which essentially parallel the Grunsky-Burton Act previously contained in the Government Code. ${ }^{362}$ This category also arguably mcludes Proposition 24's requirement that committee chairpersons and vice-chairpersons be chosen from different parties, inasmuch as Speaker Brown voluntarily implemented such a scheme im the 1981-82 legislature. ${ }^{363}$

The third category consists of those innovations in Proposition 24 that, while new to California, reflect the rules or practice of some other state legislatures. Based on their use in other jurisdictions, one might presume these procedures do not seriously threaten the legislature's governmental role or stature. A recent survey by the National Conference of State Legislatures reveals that as many as fifteen states do require some forn1 of partisan balance on legislative committees. ${ }^{364}$ In addition, a number of state bodies do not rely on the majority party's leaders to appoint committee members. Instead, this distinct minority of state legislatures uses either a Committee on Committees or the two parties' caucuses to assign members to committees. ${ }^{365}$ Finally, without being required by law or rules to do so, "a number of states routinely attempt to achieve proportional balance in staffing."

It could be argued that, while these procedures are followed in other

358. CAL. Gov'T CoDE $\S \S 9936-9937$ (West Supp. 1986).

359. Id. § 9925 .

360. Id. § 9920.

361. See Joint Hearings, supra note 19, at 8-9.

362. See supra note 37.

363. See California Journal Ballot Proposition Analysis, supra note 19, at 148 (separately paginated as 6 .

364. Joint Hearings, supra note 19, at 122.

365. Id.

366. Id. at 124. 
states, the California Legislature has made an implicit judgment that they do not serve the peculiar interests and needs of California's government. In this sense, Proposition 24's imposition of these measures could be said to undermine the legislature's effectiveness-as the legislators themselves have judged it. Yet, tlis argument seems especially vulnerable to the constitutional priciple of restramed power that, as noted earher, tips the balance in favor of imitiatives. By enacting Proposition 24, the voters second-guessed the legislature about the efficacy of procedural clianges, and they had the example of other states to support their judgment.

The fourth and final category mcludes those provisions that change the structure of the legislature in ways that neither it nor other states' lawmaking bodies have contemplated. Chief among these are Proposition 24's numerous requirements of two-thirds votes to implement various procedures. Under the ternis of the imitiative, for example, the Assembly and Senate can ouly adopt rules by a two-thirds vote at the beginning of each session, ${ }^{367}$ committees can only be established by twothirds vote, ${ }^{368}$ and any deviation from partisan balance in the allocation of resources requires a two-thirds vote of the relevant cliamber's Rules Committee. ${ }^{369}$ Similarly, neitlier the Assembly Speaker nor the Senate President can act in the name of lis respective Rules Committee without express authorization from two thirds of its members. ${ }^{370}$

Majority rule is a traditional and vital part of representative government. ${ }^{371}$ Deviations from the principle are rare and usually reserved for extraordinary matters, as with the federal Constitution's requirement of a two-thirds vote to approve constitutional amendments ${ }^{372}$ or to convict impeached officials. ${ }^{373}$ California is one of the few states that apphies a two-thirds requirement to the enactment of substantive legislation. The state constitution stipulates that appropriations must receive two-thirds approval in each chamber. ${ }^{374}$ The wrangling, delays, and armtwisting that accompany annual budget votes in California suffice to demonstrate the difficulty of superinajority requirements. For tlis reason, a court might find that the superniajority provisions in Proposition 24 do

367. CAL. Gov'T CODE $\S 9920$ (West Supp. 1986).

368. Id. $\S 9922$.

369. Id. $\S 9931$.

370. Id. $\S \S 9912,9916$.

371. See, e.g., J. Choper, Judicial Review and the National Political Process 4 (1980) ("Whether one looks to such classical theorists as Aristotle, Locke, and Rousseau, to such mainstays of American political thinking as Madison, Jefferson, and Lincoln, or to this nation's constitutional developinent from its origin to the present time, majority rule has been considered the keystone of a deinocratic political system in both theory and practice." (footnote omitted)).

372. U.S. CONST. art. V.

373. U.S. CONST. art. I, $\S 3$, cl. 6.

374. CAL. CONST. art. IV, $\$ 12(\mathrm{~d})$. 
threaten to injure the legislature's effectiveness and upset the balance of governmental powers. ${ }^{375}$

On the other hand, these particular supermajority provisions do not touch inost facets of the legislature's business, nor are they so obviously dangerous. It seens unlikely, for example, that the creation of committees would become so controversial that a minority would exploit this two-thirds vote requirement in order to tie up the legislature. Adoption of each chamber's rules at the beginning of a session offers greater opportunities for legislative sabotage, but the consequences when a chamber proceeds without standing rules for a while are certainly less cataclysinic than when the state is deprived of a budget. Morever, these supermajority requirements must be placed in perspective. While they may be the most dramatic of Proposition 24's provisions, they are far milder than other "reforms" that voters might try to impose by initiative. As noted earher, for example, if voters were truly disenchanted with the legislature's committee system, they might require the full senate and assembly to debate and vote on every bill imtroduced during a session. Such a "reform" initiative would probably jeopardize the legislature's ability to function; if so, it should be invahidated. By contrast, Proposition 24's supermajority provisions seen 1 relatively moderate and could be upheld by the courts as a valid exercise of the public's initiative power.

\section{CONCLUSION}

This Comment has sliown that the conflict between the rulenuaking clause and the imitiative power is far less clear than the Cahifornia courts assumed when they lield that nearly all of Proposition 24 is unconstitutional. Nothing in the intiative power itself precludes the voters' use of ballot propositions to establish legislative procedures. An examination of the rulemaking clause has found several plausible purposes that the clause may serve. But only one of these purposes-that of strengthening the system of representation by facilitating a legislature's deliberative process-creates a possible conflict witl1 Proposition 24. In liglit of these findimgs, the discussion has concluded by evaluatimg whether any of Proposition 24's provisions threaten the legislature's ability to function effectively as a representative body.

This section-by-section approach to assessing an initiative's constitu-

375. As previously noted, Proposition 24 does contain a severability clause. CAL. Gov'T CoDE $\S 9906$ (West Supp. 1986). The supermajority provisions apppear to be severable under the Califormia Supreme Court's current standard: these provisions "can easily and accurately be mechanically severed" and the remainder "constitutes a completely operative expression of the legislative intent [andl are [not] . . so connected with the rest of the statute as to be inseparable." " Santa Barbara School Dist. v. Superior Court, 13 Cal. 3d 315, 331, 530 P.2d 605, 618, 118 Cal. Rptr. 637, 650 (1975) (quoting In re Portnoy, 21 Cal. 2d 237, 242 (1942)). 
tionality - balancing the voters' claims to reform against the need to preserve the legislative branch's role in the balance of powers-is a better method of resolving the matter than the one the courts adopted. Judicial deference to parliamentary autonomy is appropriate when parties to a lawsuit simply ask a court to interfere in the internal conduct of a coordinate branch of government. But the issue in the present case is quite different. By enacting Proposition 24, California voters asserted a right to correct perceived abuses in their legislature by exercising their own lawmaking power. The resulting constitutional conflict is without precedent.

The California courts attempted to finesse this constitutional dilemma by invoking history. The state constitution, according to the court of appeal, bestows its mantle of authority upon the legislature rather than the voters because the rulemaking clause "was enacted by the people against a history of parliamentary common law."376 But support for the court's reading of that history proves elusive. More importantly, history alone cannot resolve conflicts between constitutional clauses "whose specific implications for each age were meant to be determined in contemporary context." 377 This Comment has sought to integrate what can be gleaned from history with California's modern structure of government. By accommodating the rulemaking power and direct democracy, the proper balance between representative sovereignty and popular sovereignty can be preserved.

James E. Castello*

376. People's Advocate v. Superior Court, 181 Cal. App. 3d 316, 322, 226 Cal. Rptr. 640, 643 (1986).

377. Ely, supra note 175 , at 400 .

* B.A. 1977, Yale University; third-year student, Boalt Hall School of Law, University of California, Berkeley. 
